\title{
Governing Sustainable Subjects: Environmentality in Polity, Economy and Civil Society
}

\author{
By
}

Morgan J. Hamlin

\begin{abstract}
A thesis submitted to Victoria University of Wellington in fulfilment of the requirements for the degree of Master or Arts in Sociology
\end{abstract}

Victoria University of Wellington 


\begin{abstract}
"Sustainability" is a broad concept that is used to guide a diverse range of government policies, corporate governance practices, and environmental movements; promote ethical and 'green' consumer products; and to transform existing production and consumption practices, to name but a few. While these various manifestations of sustainability differ from one another, they appear to be linked by a shared narrative. In this thesis, I utilise Norman Fairclough's critical discourse analysis to investigate if and why sustainability discourses share a common narrative. I focus on the relationship between the management of the population and the supposed boundaries between the state, market, and civil society by exploring the emergence of the terms "environmental sustainability" and "sustainable consumption" within the practices and narratives of governance and self-regulation. By combining Slavoj Zizek's notion of ideology with Timothy W. Luke's concept of environmentality, and Michel Foucault's conceptions of governmentality and power, I argue that the governmentalisation of sustainability is the common thread that runs through the three narratives that I analyse. More specifically, I argue that quotidian sustainability narratives have the effect of regulating human conduct through largely apolitical and technical understandings of environmental problems, disciplinary practices, and practices of the self that appear to remove risk from the act of consumption and everyday life.
\end{abstract}




\section{Acknowledgements}

The initial idea for this thesis grew out of the discussions I had with my supervisors Patricia Nickel and Chamsy el-Ojeili. I would like to thank them for assisting me throughout the entire research process. With their guidance, suggestions, and exceptional ability to help me make sense of a vast number of sociological concepts and theories, I have been able to transform a vague idea into a coherent argument.

I would like to express my gratitude to Ian, Robyn, and Amy for supporting me during my time in Wellington. Special thanks to Jamie for his ongoing IT assistance. Lastly, to my parents, sister, and grandparents - John Hamlin, Julia Merritt, Demita Avery, and Sidney and Amy Merritt - thank you for your encouragement throughout my studies. 


\section{Contents}

Acknowledgements $\quad$ ii

Contents $\quad$ iii

List of Figures

Introduction 1

Chapter One: Conceptual Overview

The Concept of Sustainable Consumption $\quad 7$

Sustainability, the Environment, and Environmentalism 10

Sustainability and Governmentality 12

Governmentality and Civil Society 14

$\begin{array}{ll}\text { Sustainability and Neo-Liberalism } & 19\end{array}$

Chapter Two: Theoretical and Methodological Framework 23

Ideology and Governmentality 23

Ideology as a doctrine $\quad 26$

Ideology as a doctrine and governmentality 28

The material existence of ideology 31

The material existence of ideology and governmentality 34

Ideology and the subject $\quad 37$

Ideology, the subject, and governmentality 43

Methodological Framework $\quad 48$

Faircloughian critical discourse analysis: Method 51

Spheres of analysis $\quad 53$

Chapter Three: Governing Sustainably 57

Theories of the State $\quad 57$

Governmentality, Individualisation, and the State $\quad 59$

$\begin{array}{ll}\text { Defining sustainability } & 60\end{array}$

$\begin{array}{ll}\text { Sustainability as an apolitical, technical problem } & 61\end{array}$

$\begin{array}{ll}\text { Individualisation } & 62\end{array}$

$\begin{array}{ll}\text { Sustainability and hegemony } & 65\end{array}$

Discipline and Government $\quad 68$

$\begin{array}{ll}\text { Self-Governing Sustainable Subjects } & 72\end{array}$

Chapter Four: Governing the Market $\quad 80$

$\begin{array}{lr}\text { Sustainability and the Market } & 80\end{array}$

Environmental Sustainability and Corporate Governance $\quad 83$

Individualisation and depoliticisation $\quad 86$

Sustainable Power Consumption as a Disciplinary Practice 91

Sustainable Power Consumption as a Practice of the Self 95

Chapter Five: Governing Civil Society 101

Civil Society and Environmental Protection $\quad 102$

Sustainability and Environmental Activism $\quad 107$ 
Politicised individualisation 108

The Green(peace) Way in Discipline 112

Virtual Consumption, Interpassivity, and Sustainable Living 116

$\begin{array}{ll}\text { Conclusion } & 125\end{array}$

$\begin{array}{ll}\text { References } & 132\end{array}$

Appendix A: Generation Diversity Advertisement 153

Appendix B: Climate Change Advertisement 159

Appendix C: Transcript Notational Conventions 164 


\section{List of Figures}

Figure 1. Shots 1 and 9

Figure 2. "Armchair activism" 


\section{Introduction}

Over the past thirty years, the term "sustainability" has become woven into a large number of narratives that address social, economic, political, and environmental issues. Lately, the term tends to be used to interrogate a wide range of contemporary issues, such as development, climate change, over-consumption, and community well-being. This ideal of sustainability brings into focus the various ways people think about and manage present and future problems. However, the idea of sustainability also brings into focus the shifting relationships between people, society, and the environment. Issues such as development and over-consumption suggest profound transformations in the social, economic, and political spheres, as well as changes in how people interact and identify as subjects. In this research, I focus on the relationship between the management of the population and the supposed boundaries between the state, market, and civil society by discussing the emergence of sustainability within the practices of governance and underlying governing narratives.

Within New Zealand, the idea of environmental sustainability appears to have emerged in the 1960s from within civil society, so that the environmental impact of industrial activity could be regulated. For example, while the concept of sustainability was relatively unknown until the publication of the Brundtland Commission's 1987 report on sustainable development and environmental issues, as an idea, it underpinned New Zealand-based Nature conservation and environmental movements (World Commission on Environment and Development [WCED], 1987). Notably, the decision to build the Manapouri Power Station so that it could supply the Tiwai Point aluminium 
smelter plant ran into opposition when environmental protesters argued that this decision would damage the surrounding ecosystem (Dann, 2003, p. 370).

In contrast to environmental sustainability, the idea of sustainable consumption emerged in the early 1970s with the publication of the Club of Rome Report, Limits to Growth, which focused on contemporary consumption and production processes, and consumerism (Dann, 2003, pp. 370-371). In New Zealand, the idea of consuming sustainably materialised as a form of non-violent direct action. Various attempts were made to disseminate environmental messages by 'walking the walk': that is, by protesting, boycotting businesses that were environmentally unfriendly, establishing community gardens, and reducing, reusing, and recycling domestic waste (Dann, 2003, p. 371). This can be seen with the growth in the number of intentional communities during the 1960s and 1970s, which were attempts at creating "that better life within the confines of the larger society but in various ways separate from it" (Sargisson \& Tower Sargent, 2004, p. 1).

By the 1980s, sustainability gradually entered into the practices of governance with the introduction of the 1986 Environment Act and the subsequent establishment of the Ministry for the Environment (MfE). With the growing importance of environmental management and planning, the concept of sustainability began appearing within the practices of governance with the Resource Management Act of 1991 and the Fourth National Government's 1996 Environment 2010 Strategy (Beehive.govt.nz, 1996). By 2003, the New Zealand government launched its Sustainable Development Programme of Action, which attempted to ensure that government activity was underpinned by the concepts of sustainability and sustainable development (MfE, 2003). Five years later, the 
Fifth Labour Government's Budget of 2007 allocated 800 million dollars towards measures that would "contribute towards environmental sustainability". The New Zealand government established six sustainability initiatives, which were to "serve as a rallying point for further action on moving central government, local government, business and individuals towards sustainability" (Beehive.govt.nz, 2007; MfE, 2007a).

The focus of my research is on the emergence of environmental sustainability and sustainable consumption within the practices of governance and self-regulation. Focusing on the apparent similarities and differences between three seemingly disparate sustainability narratives, I will explore the question: how and why have sustainability discourses entered into the practices of governance and underlying governing narratives and what is the relationship between the two? More specifically, I will question how sustainability narratives function in societies that are increasingly operating under the "systemic requirements of ecology" (Luke, 1999b, p. 122).

I will argue that the concept of sustainability has been governmentalised. That is to say, it has entered into the practices of governance and underlying governing narratives as a form of governmentality that appears to regulate and environmentalise everyday human conduct according to seemingly unalterable neo-liberal and individualised understandings of sustainability. I will claim that the regulation of the population according to largely apolitical and technical conceptions of a 'sustainable' economy and society cuts across the supposed boundaries between the state, market, and civil society. I aim to demonstrate that the sustainability narratives that I analyse potentially govern human conduct by categorising and positioning individuals as 'sustainable' subjects, 
disciplining individuals and individual consumers, and by appearing to remove risk from the act of consumption and everyday life.

While I am critical of individualised forms of sustainability, I am not arguing that modifying individual lifestyles and practices is unimportant. My aim is to question individualised sustainability narratives that encourage people to shape their everyday lifestyles and practices according to apolitical and technical understandings of sustainability (understandings that are grounded in the individual and particular levels, rather than the societal, structural, or institutional levels). That is to say, I will be questioning the various forms of knowledge and thought that are utilised in practices of governing (M. Dean, 2010, p. 42).

My research, therefore, is situated within critical forms of social, political, and environmental theory. I draw on Luke's critical analyses of environmental discourses, Foucault's ideas of governmentality and power, and Zizek's three dimensional conception of ideology, because they offer theoretical and analytical tools that can be used to analyse and question individualised sustainability narratives. Also, there is at present no New Zealand-based research, to my knowledge, that focuses on sustainability, governmentality, and the supposed boundaries between the state, market, and civil society, and only a small body of New Zealand research that questions individualised sustainability discourses (see Le Heron, 2008; Lewin, 2009; Munshi \& Kurian, 2005). The present research thus offers an original contribution to the fields of environmental and political sociology.

In chapter one, I situate my argument by discussing the concept of sustainable consumption and its links with environmentalism, governmentality, and neo-liberalism. 
Moreover, I examine the various facets of sustainability and how they have shifted over time. In chapter two, I expand on the regulatory dimensions of sustainability by focusing on how it functions as governmentality. Here, I position my argument theoretically by constructing a framework that combines Zizek's three dimensional conception of ideology with Luke's concept of environmentality and Foucault's conceptions of governmentality and power. I then discuss how I employ, methodologically, my theoretical framework by outlining Fairclough's critical discourse analysis and exploring why I chose the MfE, Genesis Energy, and Greenpeace's narratives as my analytical focus. I claim that Fairclough's critical discourse analysis is an appropriate methodological tool to employ because it incorporates Foucaultian discourse analysis and ideology critique.

With this theoretical framework established, chapters three, four, and five analyse three sustainability narratives that are generated from within the spheres of the state, market, and civil society. I begin each chapter with a discussion of how sustainability functions within the practices of governance and underlying governing narratives. I then explore whether these narratives are forms of governmentality that exert power over everyday life. Within each chapter, I discuss if and how these narratives categorise individuals as 'sustainable' subjects, discipline individuals and individual consumers to live and consume 'sustainably', and if and how they appear to remove risk from the act of consumption and everyday life. In chapter three, I discuss how sustainability functions within the practices and narratives of state governance by focusing on state autonomy theory and structuralist theories of the state. I argue that the MfE's narrative appears to shape individual and business responsibilities through environmentalised disciplinary 
practices and practices of the self that encourage people and businesses to consume and produce without constraint and/or environmental risk.

In chapter four, I shift my focus to the market sphere. I discuss how Genesis Energy employs two market-based "discourse types" (ecocommercialism and 'green' consumerism) in their sustainability narrative (Fairclough, 1992, p. 124). I argue that, like the MfE, Genesis Energy's narrative is a form of environmentality. However, instead of encouraging people to consume without constraint and/or risk, it encourages people to live and consume 'sustainably'.

After exploring the sustainability narratives that are generated within the spheres of the state and market, I then, in chapter five, analyse Greenpeace's sustainability narrative and discuss how it differs from the MfE's and Genesis Energy's narratives. I analyse Greenpeace's narrative as a global civil society narrative that draws on the ideas of critical climatology and deep ecology. I argue that although this narrative differs from the MfE's and Genesis Energy's narratives it is also a form of environmentality that encourages individual's to adopt everyday, 'green' practices and to live and consume 'sustainably'.

Having explored the governmentalisation of sustainability across the spheres of the state, market, and civil society, I conclude by summarising my research, and restating and assessing my argument. Although my analysis is limited to three narratives, I hope that my discussion will illuminate how the governmentalisation of sustainability has implications for how we understand the shifting relationships between individuals, society, and the state. 


\section{Chapter One: Conceptual Overview}

\section{The Concept of Sustainable Consumption}

Sustainability, as a general guide for organising human activity, is a multifaceted concept that can refer to sustainable development, consumption, and production, or it can refer to economic, environmental, financial, and social sustainability. While many of these concepts cannot be discussed in isolation, I focus on sustainable consumption and environmental sustainability because they appear to have simultaneously entered into the practices of governance and self-regulation. Moreover, narratives of sustainable consumption and environmental sustainability seem to link the regulation of everyday life with the management of the population.

Although the idea of sustainable consumption emerged in the 1990s, the idea that sits behind it, unsustainable consumption, has been used by social and economic theorists since the late nineteenth century (Smart, 2010, p. 174). For example, Thorstein Veblen (1899/2008, p. 41), although he did not explicitly use the idea of unsustainable consumption, argued that "conspicuous consumption" is wasteful because it does not "serve human life or human well-being on the whole". In contrast, Max Weber (1930/2002, p. 123) focused on natural resource use and capitalism. According to Ulrich Beck (2010, pp. 255-256), Weber focused on how "industrial capitalism generates an insatiable appetite for natural resources which undermines its own material prerequisites". For example, Weber (as cited in Smart, 2010, p. vii) argued that "the boiling heat of modern capitalistic culture is connected with heedless consumption of resources, for which there are no substitutes". Like Weber, Herbert Marcuse (1964/1991, p. 85,1972, p. 61) argued that consumerism and monopoly capitalism are unsustainable 
or destructive because they involved the technological domination of Nature, "the destruction of resources and the proliferation of waste" (Luke, 1990, pp. 136, 159).

Although Veblen, Weber, Marcuse, and other social and economic theorists implicitly made reference to the idea of sustainable consumption, it was not until the 1970s that discussions about the links between consumption, environmental problems, and sustainability emerged. Within sustainable development debates, it was not until the 1970s that consumption emerged as an important dimension of sustainable development. According to Paterson (2008, p. 116), at the 1972 United Nations Conference on the Human Environment (the Stockholm Conference), negotiators from the 'South' challenged the idea that to help mitigate environmental degradation, developing countries need to develop in more 'sustainable' ways. The negotiators argued that in Western countries, more specifically North America, over-consumption was causing more environmental damage than industrialisation (Princen, Maniates, \& Conca, 2002, p. 3; Paterson, 2008, p. 116). In terms of the environmental impact equation ( $=$ PCT), which states that environmental Impact is equal to Population times Consumption times Technology, negotiators from Western countries challenged their argument by claiming that population growth was the most important determinant of environmental degradation. However, according to Matthew Paterson (2008, p. 116), the "Southern negotiators" argued that the focus on population growth overlooks the environmental impact of over-consumption.

Although the idea of sustainable development has gained increasing attention since the release of the Brundtland Commission's 1987 report, Our Common Future, which outlined a working definition of the concept, it was not until the 1992 Rio Earth 
Summit that the importance of consumption was recognised within sustainability debates (WCED, 1987). Chapter four of the 1992 United Nations Conference on Environment and Development (UNCED) report (as cited in Paterson, 2008, p. 116), titled Agenda 21, focused on the connection between sustainability and consumption. According to Paterson (2008, p. 116), Agenda 21 "located the origins of environmental degradation in consumption patterns". Because of this shift in focus to consumption, sustainable consumption became an important concept within sustainability and sustainable development debates.

While sustainable consumption is an important aspect of sustainability, it remains a deeply contested concept that has a myriad of competing definitions. There is no stable definition of sustainable consumption due to the ambiguity of the terms that are used. The working definition of sustainable consumption that is used by the United Nations Commission on Sustainable Development (UNCSD) was developed in 1994 at the Oslo Symposium $^{1}$ (Gunneng, 2006, p. 1). The 1994 Oslo Symposium defines sustainable consumption as:

The use of goods and services that respond to basic needs and bring a better quality of life, while minimizing the use of natural resources, toxic materials and emissions of waste and pollutants over the life cycle, so as not to jeopardize the needs of future generations. (As cited in Paterson, 2008, p. 111)

Sustainable consumption, therefore, remains a working definition because some of the concepts that are used can be interpreted in a number of different ways (Paterson, 2008,

\footnotetext{
${ }^{1}$ More specifically, The Soria Moria Symposium: Sustainable Consumption and Production, January 1994, Oslo, Norway (see Gunneng, 2006, p. 1).
} 
p. 114). First, the Oslo Symposium's definition of sustainable consumption as "the use of goods and services that ... [minimise] the use of natural resources", implies that there are various degrees of sustainability (as cited in Paterson, 2008, p. 111). Second, the concept of "needs" is a social concept that has multiple meanings that are specific to certain times, places, societies, and cultures (Princen et al., 2002, p. 1). Finally, consumption is an ambiguous term because it is interconnected with production. While the connection between consumption and production can change over time, consumption is based on the assumption that goods and services will be produced and production is based on the presumption that people will consume (Smart, 2010, p. 4; Luke, 1997b, p. 15).

Consumption refers to the producers of products and services, not only to individual consumers. More specifically, it refers to both "aggregate throughput in materials and energy, and at the same time to the individual acts of consumption-purchasing and use of goods" (Paterson, 2008, p. 120). Paterson (2008, p. 120) argues that the two dimensions of consumption are commonly conflated in sustainable consumption discourses and so individuals are seen as consumers, while governments, industries, and businesses are not. For example, Paterson (2008, p. 120) claims that the Organisation for Economic Cooperation and Development's (OECD) discussion on sustainable consumption reduces it to "household consumption".

\section{Sustainability, the Environment, and Environmentalism}

The idea of sustainability is also shaped by how the environment is defined by environmentalists and environmental scientists. The environment is not a "natural sphere of ecological processes", but is a social and historical concept that is often used interchangeably with the terms "Nature", "ecology”, “conservation”, “deforestation”, or 
other terms that are linked with either preservation or degradation (Luke, 1999a, pp. 120, 129). Until the 1970 s, the concept of the "environment" only had biological and zoological dimensions; it did not refer to the natural environment (Luke, 1999a, p. 121). The environment was defined in several dictionaries, such as the Oxford English Dictionary (1933) (as cited in Luke, 1999a, p. 121), as either "the conditions under which any person or thing lives or is developed" or "the sum-total of influences which modify and determine the development of life or character". Luke (1999a, pp. 120-121) argues that it was not until the 1970s that dictionary definitions of the environment became associated with the natural environment and its protection or improvement, which can be seen by the inclusion of the adjective "environmental" and the noun "environmentalist".

Although the environment has become associated with protecting the natural environment, environmentalism also creates a way of knowing how to protect it. According to Luke (1999a, p. 126), "an environment is the result of the action signaled by the verb to environ", which is a strategic action used by the military and police to surround and enclose an area. Environmentalists, therefore, protect the environment by marking out a space, whether it is a region, territory or planet, and then enclosing it within disciplinary frameworks, such as resource management (Luke, 1999a, pp. 126127). In other words, the environment is protected, not through human non-intervention, but through constant supervision and monitoring (Luke, 1999a, p. 127).

The concept of environmental sustainability, therefore, is dynamic and changes according to how the environment is understood and defined. Nominally defined, environmental sustainability can refer "to the long-term maintenance of valued environmental resources in an evolving human context" (Esty, Levy, \& de Sherbinin, 
2005, p. 11). However, different understandings of the environment can produce conceptions of environmental sustainability that vary widely. For instance, according to Esty et al. (2005, p. 11), economists and other resource managers "often emphasize an accounting approach that focuses on the maintenance of capital stocks", whereas environmentalists "focus on natural resource depletion and whether the current rates of resource use can be sustained into the distant future".

\section{Sustainability and Governmentality}

The supervision of the environment that Luke (1999a, p. 127) describes, helps explain how environmental and sustainability discourses have entered into forms of governmentality. Governmentality, as Foucault (1991b) conceptualised it, is:

The ensemble formed by the institutions, procedures, analyses and reflections, the calculations and tactics that allow the exercise of this very specific albeit complex form of power, which has its target population, as its principal form of knowledge political economy, and as its essential technical means apparatuses of security. (p. 102)

Governmentality in other words, is a form of power, or "art of government", that governs effectively by bringing the population into all of its observations and "savoir" to ensure the "welfare of the population, the improvement of its condition, the increase of its wealth, longevity, health etc." (Foucault, 1991b, pp. 92, 100). According to Nikolas Rose (1999, p. 23), it maximises "the forces of the population collectively and individually" by

\footnotetext{
${ }^{2}$ According to Alan Sheridan Smith (as cited in Foucault, 1972/2002, p. 16), the "English 'knowledge' translates the French 'connaissance' and 'savoir'. Connaissance refers here to a particular corpus of knowledge, a particular discipline - biology or economics, for example. Savoir, which is usually defined as knowledge in general, the totality of connaissances, is used by Foucault in an underlying, rather than an overall, way". Foucault (1972/2002. pp. 16-17) suggests that "savoir refers to the conditions that are necessary in a particular period for this or that type of object to be given to connaissance and for this or that enunciations to be formulated".
} 
managing the population not only at the level of what Foucault (1991b, p. 102) calls its "aggregate effects", but also "in its depths and details". The older forms of power, sovereign power (the authority over "a territory and consequently on the subjects who inhabit it") and disciplinary power ("hierarchical observation, normalizing judgement and their combination in a procedure that is specific to it, the examination") are not replaced by governmentality, but are important forms of power in the management of a population (Foucault, 1991b, pp. 93, 102, 1977/1991a, p. 170). Governmentality, therefore, is a broad term that covers the practices of governance ${ }^{3}$ and governing. It can be used to analyse how populations, groups of people, and individuals are governed, for example, how a state or extra-state institution governs, and how people govern themselves through “technologies of the self” (Eikenberry \& Nickel, 2006, p. 3; Foucault, 2000b, p. 282).

When environmental and sustainability discourses are analysed as a form of, what Luke (1999b) calls, "green governmentality" or "environmentality", they deepen what Foucault (1991b, p. 92) understood as governmentality by introducing environmental issues into the art of government. Although Foucault (2004, p. 245) did not focus on the connections between environmental issues and governmentality, he did highlight the importance of managing the relations between people and their environment, which "includes [the] geographic, climatic, or hydrographic environment" and the built or urban environment. According to Luke (1999b, p. 122), environmental issues and sustainability highlight the importance of conserving resources and avoiding overpopulation, species extinction, and environmental pollution in order to not only protect its 'safety', but to also

\footnotetext{
${ }^{3}$ According to H. Brinton Milward and Keith G. Provan (2000, p. 360), governance is an "inclusive term, concerned with creating the conditions for ordered rule and collective action, often including agents in the private and nonprofit sectors as well as within the public sector. The essence of governance is its focus on governing mechanisms (grants, contracts, and agreements) that do not rest solely on the authority and sanctions of government (Stoker 1998, 17)".
} 
ensure "balanced growth or ecological harmony for its constituent populations of human and non-human beings". Incorporating sustainability and environmental issues into the art of government therefore, is now an important part of ensuring the "welfare of the population, the improvement of its condition, the increase of its wealth, longevity, health etc.” (Foucault, 1991b, pp. 92, 100). Like governmentality, Luke (1997a, p. 196, 1995/2006a, pp. 264, 266) argues that environmentality is an attempt to govern “individuals and/or large human populations" by restructuring "today's ecologically unsound society" according to "specific understandings about the economy", society, and the environment.

\section{Governmentality and Civil Society}

Environmentality and governmentality not only introduce environmental issues into the art of government, but also separate the question of government from the concept of the state, which, subsequently, also raises questions about the boundaries between the state and society (Foucault, 1991b, p. 92; M. Dean, 2010, p. 16; Mitchell, 1991, p. 77). Because I analyse sustainability narratives that are generated within the supposedly distinct spheres of the state, market, and civil society, I will briefly contrast the idea that civil society is a sphere that is separate from the state ${ }^{4}$ and the economy with Foucault's (1991b) concept of governmentality, which is based on the collapse of the state, economy, and civil society as three distinct spheres (Hardt, 1995, p. 33).

\footnotetext{
${ }^{4}$ There are also debates around the definition of the state and its relationship with society, and the economy (Mitchell, 1991, p. 77). Nicholas Abercrombie, Stephen Hill, and Bryan S. Turner (2001, p. 343) define the state as "a set of institutions governing a particular territory, with a capacity to make laws regulating the conduct of people within that territory, and supported by revenue deriving from taxation". Although this definition of the state seems unproblematic, there are a number of theories that debate the state's autonomy from society. For example, Weberian state-centred theories focus on how the state has its own goals and interests that are potentially autonomous from society and the economy, whereas some Marxist, societycentred theories of the state focus on how the state serves the interests of the capitalist classes (Skocpol, 1985, p. 9; Abercrombie et al., 2000, p. 345; Goldfinch, 2003, p. 548).
} 
Civil society is a broad concept that has undergone at least two major transformations since its development in classical Greek and medieval thought (Ehrenberg, 1999, p. xi). In classical Greek and medieval thought, civil society was intimately connected with the state. As it was conceptualised within these two strands of thought, John Ehrenberg (1999, p. xi) argues that civil society was associated with "politically organized commonwealths" and the "law-governed associations protected by the coercive power of the state". In classical Greek thought, there was an understanding that people lived in distinct, yet interconnected, spheres, which were characterised by people's different associations and relations with each other (Ehrenberg, 1999, pp. 3-4). However, these spheres were not separate from the state, but were made possible by a form of political power that existed "to serve the welfare of the city and its citizens" (Ehrenberg, 1999, pp. 3-4).

In contrast, modern conceptions of civil society, which were developed from the seventeenth to the nineteenth century, separated civil society from the state. During this time period, civil society was thought of broadly and included all extra-state institutions and activities (Alexander, 2006, p. 24). English and Scottish theorists, such as Thomas Hobbes, John Locke, Adam Ferguson, and Adam Smith argued that separating the state from civil society would help protect the activities of bourgeois citizens and private businesses from "the regulatory institutions of the state" (Isin, 2006, p. 65). Eighteenth and early nineteenth century French theorists, such as Jean-Jacques Rousseau and Alexis de Tocqueville also conceptualised civil society as a separate or "relatively autonomous sphere", but rather than focusing on "negative liberties" or the freedom from interference, 
they "articulated the need for positive liberties of intermediary associations, cities, organizations, societies and unions" (Isin, 2006, p. 65).

Early twentieth century conceptions of civil society separated civil society not only from the state, but also from the economy. Drawing on Hegel and Marx, Antonio Gramsci claimed that in a capitalist society there are three distinct but interconnected spheres: civil society, which includes " the so-called private' organisations like the church, the trade unions, the schools etc." and other social and cultural relations that are distinct from the relations of production; the economy, which includes the relations of production; and the state, which is distinguished from civil society by its public apparatuses that have "a monopoly of coercion" (Simon, 1982, p. 68). Jean L. Cohen and Andrew Arato (1992, p. 143) claim that Gramsci separated civil society from the state and the economy in order to theorise how the generation of cultural and social hegemonic consent is an important variable in stabilising and reproducing the "existing system".

The separation of civil society from the state and the economy underpins contemporary understandings of civil society. Bent Flyvbjerg (1998) argues that most civil society theorists would agree that:

Civil society has an institutional core constituted by voluntary associations outside the sphere of the state and the economy. Such associations range from, for example, churches, cultural associations, sports clubs, and debating societies to independent media, academies, groups of concerned citizens, grass-roots initiatives and organizations of gender, race and sexuality, all the way to occupational associations, political parties and labour unions (Habermas 1992a: 453). (p. 210) 
For example, in contemporary research the idea that civil society is distinct from the state and the economy, according to Engin F. Isin (2006, p. 66), has been used in connection with democracy to theorise how in democratising countries "intermediary institutions . . . resist non-democratic tendencies of states and multinational business corporations".

Although theorists might agree with this distinction between the three spheres of state, economy, and civil society, they might not claim that civil society 'actually exists' as an independent sphere. Jeffery C. Alexander (2006, p. 31), for example, argues that the idea of civil society as a "solidary sphere" does not "exist as such", but "can only be sustained to one degree or another. It is always limited by, and interpenetrated with, the boundary relations of other, non-civil spheres". While civil society might not 'actually exist' as a "solidary sphere", Alexander (2006, pp. 31, 33) argues that identifying civil society with capitalism degrades civil society's "universalizing moral implications and the capacity for criticism and repair that the existence of a relatively independent solidary community implies".

While Gramsci and Alexander's (2006, p. 33) idea of civil society highlights its democratic potential, Foucault's (1991b) conception of governmentality and power collapses the supposed boundaries between the state, market, and civil society. Rather than being a democratic, autonomous sphere, civil society and its institutions produces normalised subjects and subjectivities that are connected and coordinated with the state and economy (Hardt, 1995, p. 31; Foucault, 2007, p. 2). Foucault (2008a, pp. 296-297) argues that civil society is "a concept of governmental technology" that is not against or outside the state and the economic spheres, but is a sphere or "concrete ensemble within 
which these ideal points, economic men, must be placed so that they can be appropriately managed". For instance, Michael Hardt (1995) argues that:

The institutional labour union ... [can be] viewed not so much as a passage for the expression of worker interests to be represented in the plurality of rule, but rather as a means to mediate and recuperate the antagonisms born of capitalist production and capitalist social relationsthus creating a worker subjectivity that is recuperable within and actually supportive of the order of the capitalist State. (p. 31)

Rather than trying to find the essence of civil society, as Gramsci and Alexander (2006) do, Foucault (2008a, p. 76-78, 1991b, p. 103) investigates the distinction between the state and civil society by exploring the "governmentalization of the state" on the basis of governmentality and disciplinary power. That is to say, Foucault, according to Mitchell Dean (2010, p. 223), charted how "the state came to take on the function of the care of populations and individuals". Foucault (1978/2008b, p. 94, 2008a, pp. 76-77) argues that the separation of civil society from the state is problematic because it assumes that the state exists as an "autonomous source of power" that exerts power from the powerful realm of the state down to, what Andreas Kalyvas (2002, p. 109) calls, "the power-free realm" of civil society. The governmentalisation of the state, however, refers not only to the shift from a "state of justice" (a sovereign state) and an "administrative state" (a disciplinary state) to a "governmental state", which has as its "primary target the population", but also to the shift from an autonomous view of power towards a type of governmental power that "comes from everywhere"; a networked power that "take[s] shape and come[s] into play" across various points in society and is "the basis for wide- 
ranging effects of cleavage that run through the social body as a whole" (Foucault, 1978/2008b, p. 94, 1991b, pp. 102-104).

The governmentalised state also relies on 'de-institutionalised" 5 forms of disciplinary mechanisms to help discipline and manage the population (Foucault, 1977/1991a, pp. 211-212). As Foucault (1977/1991a, p. 208) argues, the productive increase in power can only be achieved if disciplinary power is "exercised continuously in the very foundations of society, in the subtlest possible way". The state benefits from, and relies on, the dispersal of disciplinary mechanisms throughout society because civil society institutions function as "centres of observation" that continuously survey and discipline the population (Foucault, 1977/1991a, p. 212). This shift to a governmentalised state can be seen in, what Eva Sorensen and Jacob Torfing (2005, pp. 199-200) call, the gradual transition from "government to governance", where political and public policy decisions are no longer "confined to the formal structures of government", but are also "formulated and implemented through a plethora of formal and informal institutions, mechanisms and processes that are commonly referred to as governance”.

\section{Sustainability and Neo-Liberalism}

Although environmentality and governmentality are not limited to specific political or power regimes, sustainability narratives embody a number of assumptions about the relationship between the individual, state, and economy that are associated with neo-liberal governmentality. Neo-liberalism is the combination of the ideas of individual freedom and free market principles (Harvey, 2005, p. 20). David Harvey (2005, p. 2) defines neo-liberalism as "a theory of political economic practices that proposes that

\footnotetext{
${ }^{5}$ That is to say, forms of disciplinary mechanisms that are dispersed throughout civil society (Foucault, 1977/1991a, p. 212).
} 
human well-being can best be advanced by liberating individual entrepreneurial freedoms and skills within an institutional framework characterized by strong private property rights, free markets, and free trade". Similarly, Foucault (2008a, p. 148) argues that the "multiplication of the 'enterprise' form within the social body is what is at stake in neoliberal policy". For Foucault (2008a, p. 131), then, neo-liberalism "is not a question of freeing an empty space, but of taking the formal principles of a market economy and referring and relating them to, of projecting them on to a general art of government".

The creation of an institutional framework, according to Foucault (2008a, p. 120), is an important dimension of neo-liberalism that helps distinguish it from liberalism. Foucault (2008a, pp. 118-119) argues that neo-liberalism is not simply laissez-faire or classical liberalism, where the most salient aspect of the market is either free exchange or "free and full competition" (Foucault, 2008a, p. 119). Neo-liberalism is underpinned by the idea that "free and full competition" does not "define the market" because the market is not something that arises naturally or spontaneously (Foucault, 2008a, pp. 119-120). Competition, for example, has its own logic and structure; "its effects are only produced" if certain conditions, which are "carefully and artificially constructed", are met (Foucault, 2008a, p. 120). Therefore, neo-liberalism, according to Foucault (2008a, p. 132), "is a matter of a market economy without laissez-faire, that is to say, an active policy without state control"; it is characterised by "permanent vigilance, activity, and intervention".

The mixing of individual freedom and free market principles within sustainability narratives is manifest in the idea that individuals are responsible, or partly responsible for environmental problems and sustainability. Although the individualisation of environmental responsibility is connected with a number of different social and cultural 
practices, such as 'green' consumerism, governments and businesses in Western countries have utilised the narrative of neo-liberalism to assign environmental responsibility to individuals "and their decisions in the marketplace" (Maniates, 2001, p. 39). Because of the widespread adoption of neo-liberal thought in Western countries during the 1980s, governments and businesses claimed that there would be reductions in environmental problems if markets were allowed to operate freely according to supply and demand (Maniates, 2001, p. 39). According to Michael F. Maniates (2001, p. 39), US President Ronald Reagan argued that his administration would not introduce environmental policy that would coerce businesses "to behave responsibly towards the environment" because he believed that "personal responsibility, corporate initiative, and limited government" could solve environmental problems. Instead, Ronald Reagan introduced environmental policies that were based on "zero-coercion" or "win-win" scenarios (Maniates, 2001, p. 39). For example, individuals would demand greener technology, products, and services, businesses would meet the demand, and governments would introduce policy to encourage these changes without interfering in the operation of the market (Maniates, 2001, p. 39). If people do not demand greener products and technology, then individual consumers become responsible for environmental problems because if people really wanted 'sustainable' products and services they would demand these products and services and the market would respond accordingly (Maniates, 2001, p. 40; Princen et al., 2002, p. 321). Also, framing environmental problems and sustainability in terms of consumption and supply and demand, helps shift the responsibility for them onto individual consumers by framing it as a problem of governing and caring for the self (Foucault, 2000a, p. 88; Lemke, 2001, p. 201). Rather 
than being social risks, environmental problems and sustainability are turned into private risks that can be solved through self care (Lemke, 2001, p. 201).

In summary, the concept of sustainability appears to have emerged not simply as a response to the growing concerns about environmental degradation, but also from a variety of overlapping, economic, governmental, and social concerns. In this chapter, I have explored the various definitions and conceptions of sustainable consumption and environmental sustainability, their relationship to governmentality, and how they have changed over time. I have argued that the emergence of sustainability as a practice of regulating human activity is intimately connected to neo-liberal governmentality, which highlights how the protection and regulation of the environment is not divorced from the regulation of human conduct. In the following chapter I outline my theoretical and methodological framework. 


\section{Chapter Two: Theoretical and Methodological Framework}

As I have discussed, sustainability is a multi-dimensional concept that is connected with the regulation of the environment and human conduct. However, analysing sustainability as a regulatory practice raises the issue of how sustainability narratives function as governmentality. To explore this issue, I combine the concept of ideology with Foucault's conceptions of governmentality and power. This chapter is divided into two sections. In the first section, I outline and construct my theoretical framework by framing it within Zizek's three dimensional conception of ideology and Foucault's analytics of power and governmentality. In the second section, I discuss how I will employ, methodologically, my theoretical framework. I outline Fairclough's critical discourse analysis and discuss why I have chosen the MfE, Genesis Energy, and Greenpeace's narratives as my analytical focus.

\section{Ideology and Governmentality}

Foucault's conceptions of governmentality and power are not usually combined with the concept of ideology and ideology critique (see M. Dean, 2010, p. 79; Vighi \& Feldner, 2007). However, I treat these concepts together in order to theorise how individualised sustainability narratives potentially normalise, and work on, "the way people see themselves and their world" (Craib, 1992, p. 156). Although the concept of ideology can be defined in a number of ways, I connect ideology to power relations and how, according to John B. Thompson (1990, p. 56), "meaning serves to establish and sustain relations of domination". More specifically, I will be blending Zizek’s (1994, p. 63) conceptualisation of ideology with governmentality and Luke's (1999b, pp. 121-122) concept of environmentality to help create a lens through which to analyse how 
sustainability narratives promote governmentalised and individualised understandings of how to live and consume in contemporary societies that are operating under the "systemic requirements of ecology".

Framing sustainability as an ideology also opens up different ways of analysing sustainability discourses. Because of the limitations of understanding and analysing sustainability narratives through a Foucaultian lens, I bring together Zizek's (1994) conceptualisation of ideology with Foucault's conceptions of governmentality and power. Although I will highlight the similarities between ideology critique and Foucault's conceptions of discourse and governmentality in the following section, Zizek goes beyond Foucault by combining the psychoanalytic ideas of fantasy, enjoyment, and the unconscious into his theory of ideology. By incorporating these ideas, Zizek (1994, 2008a) is able to account for how rituals and practices can function without people believing in them, whereas Foucault (1980b, p. 119) does not account for how rituals and practices can function without belief primarily because he abandoned the notion of ideology.

Foucault (1980b, p. 118) provided a number of reasons for why he did not use the notion of ideology. First, Foucault (1980b, p. 118) argues that ideology creates a problematic distinction between 'true' and 'false' or science and ideology. Second, ideology, according to Foucault (1980b, p. 118), "refers . . to something of the order of the subject", which is problematic because it suggests that there is a human nature or stable subject (Kumar, 2005, p. 37). Third, Foucault (1980b, p. 118) argues that ideology is connected with the problematic idea of economic determinism: "ideology stands in a secondary position relative to something which functions as its infrastructure, as its 
material, economic determinant”. Finally, Foucault (1978/2008b, pp. 93-94, 2007, p. 2) rejected this view of ideology because it presumes that power, rather than being a complex strategy that is woven into social relations, is something that exists alongside social relations and, when seized by a person or institution, modifies, disturbs, or represses them. For example, Foucault argues $(2007$, p. 2) that there "are not family type relationships and then, over and above them, mechanisms of power. . . Mechanisms of power are an intrinsic part of all these relations and, in a circular way, are both their effect and cause". Despite not utilising the concept of ideology, Foucault (1972/2002, p. 205) does suggest that "the sciences" function ideologically. That is to say, Foucault (1972/2002, p. 204) argues that "the question of ideology that is asked of science is not . . . the question of the possible use or misuse to which it could be put; it is the question of its existence as a discursive practice and of its functioning among other practices".

I further explore this connection between ideology critique and discourse analysis in the methodology section, but for now, Foucault's (1972/2002, pp. 204-205) comments provide a starting point for how ideology and his conceptions of governmentality and power can be blended in my analysis of sustainability discourses. Although Foucault (1980b, p. 118) highlights how ideology can be problematic when it is associated with the ideas of science versus ideology, human nature, and economic determinism, Zizek (1994, 2008a), and others, have gone beyond these understandings of ideology. My description of how ideology and governmentality can be combined and used to analyse sustainability discourses, begins with Zizek's (1994, p. 63) idea that ideology can be divided into three dimensions: doctrine, belief, and ritual. 
Ideology as a doctrine. Ideology as a doctrine or the 'symptomatic reading' of ideology, as Zizek (1994, p. 63) claims, refers to "a composite of ideas, beliefs, concepts and so on, destined to convince us of its 'truth', yet actually serving some unavowed particular power interest”. Although Zizek's (1994, p. 65) 'symptomatic reading' of ideology appears to be a negative reading of ideology that frames beliefs and ideas in terms of 'true' or 'false', he focuses on how beliefs, ideas, and meanings are intricately connected to issues of power, hegemony, and other social and cultural factors. Instead of focusing on the negative dimension of ideology, Zizek (1994, p. 60) explores the positive and negative dimensions of ideology, that is, how an ideology can be both 'true' and 'false'. Zizek (1994, p. 60) argues that "a political standpoint can be quite accurate ('true') to its objective content, yet thoroughly ideological; and, vice versa, the idea that a political standpoint gives of its social content can prove totally wrong, yet there is absolutely nothing ideological about it". For example, as a doctrine, neo-liberal sustainability discourses frame sustainability as an individual problem that can be solved through the purchasing decisions of consumers in the 'free market'. If people do not consume 'sustainably', then this is the individual's problem because if people really wanted 'sustainable' products and services the market would respond according to their demands (Maniates, 2001, p. 40; Princen et al., 2002, p. 321). Neo-liberal sustainability discourses are both 'true' and 'false' in the sense that although it might be 'true' that consuming efficiently or ‘sustainably' reduces a person's ecological footprint, they are problematic or 'false' in the sense that they imply a seemingly paradoxical belief in utilising consumerism to promote environmental sustainability (Zizek, 1994, p. 60; Luke, 1997b, p. 5). 
Ideology as a doctrine can also be read as a 'sinthome', or a knot that "holds together the 'thing itself' - if one unties it, the 'thing itself' disintegrates", as opposed to a symptom, which "is a sign of a more fundamental process taking place on another level" (Zizek, 2008b, p. 206). The 'knot' refers to the tying of a ('politically neutral') "Universal" ideological notion, such as society, and a particular signifier, such as individual 'free choice' (Zizek, 2008b, p. 207). An ideological discourse is hegemonised when a particular signifier is made into a 'typical' example of the Universal (Zizek, 2008b, p. 204). The 'typical' in a "universal ideological notion”, according to Zizek (2008b, pp. 204-205), functions as a form of hegemony by colouring the Universal and "accounting for its efficiency": that is, "one has to look for the particular content which accounts for the specific efficiency of an ideological notion". For example, when analysed as an ideological doctrine, individualised sustainability discourses are underpinned by the 'universal' idea of sustainability, but are hegemonised by their portrayal of individual consumers 'freely' choosing to consume 'sustainably' (Zizek, 2008b, p. 204).

There are several dimensions of Foucault's analytics of power that connect with Zizek's idea of ideology as a doctrine. In terms of Zizek's (1994, p. 63) 'symptomatic' understanding of ideology, Foucault (1980b, p. 118) focuses on how "effects of truth are produced within discourses which in themselves are neither true nor false". Ideological doctrines attempt to convince people of their truth through "games of truth" (Foucault, 2000 b, p. 296). In a "game of truth", truth is ordered according to a system of procedures and an "ensemble of rules according to which the true and the false are separated and specific effects of power attached to the true" (Foucault, 2000b, p. 296, 1980b, p. 132). 
From a 'sinthomatic' understanding of ideology, rather than only focusing on how ideology serves certain power interests, Foucault (2000b, p. 283) focuses on how ideological doctrines or discourses are either able or not able to block a "field of power relations". Foucault (2000b, p. 283) argues that if an ideological doctrine has been deployed by an individual or social group and it is successful in convincing people of its 'truth', then an individual or social group is in "a state of domination"; the power relations that are usually circulating have been blocked or immobilised.

More specifically, however, I frame Zizek’s (1994) reading of ideology as a doctrine within Foucault's (1982, p. 777) analyses of the relationships between power, truth, and subjectivity. Ideological doctrines, as a discourse or form of knowledge about the world, not only serve certain power interests and hegemonise certain discourses, but also position people as subjects and objects of knowledge. Ideological doctrines, then, are practices that objectify, position, and categorise people as objects of knowledge, which, according to Foucault (1982, p. 777), "transform[s] human beings into subjects".

Foucault focuses on the relationships between the human sciences, objectification, and subjectivity. For example, he claims that "the productive subject, the subject who labors" is objectivised "in the analysis of wealth and of economics" (Foucault, 1982, p. 777). Similarly, I will argue that sustainability and environmental discourses position and categorise individuals as 'sustainable' and environmental subjects.

Ideology as a doctrine and governmentality. As an ideological doctrine, I claim that individualised sustainability discourses govern by positioning and categorising 'sustainable' subjects according to depoliticised understandings of environmental phenomena. Environmental sustainability represents a form of "green power/knowledge" 
or "eco-knowledge" that generates knowledge about Nature by interpreting its patterns and signs as meaningful (Luke, 1996, p. 1). Although forms of eco-knowledge are used by a range of actors and institutions, such as governments, businesses, and interest groups, it is, according to Luke (1996, pp. 1-4), usually generated within discursive frameworks that are developed by environmental scientists within research universities. Luke (1996, p. 2) argues that eco-knowledge, as developed within the university setting, is an attempt "to capture and contain the forces of Nature by operationally deploying advanced technologies, and thereby linking many of Nature's apparently intrinsic structures and processes to strategies of highly rationalized environmental management". Nature within these eco-knowledge discourses, then, is transformed into a productive, natural resource that is managed through the performative, technoscientific disciplinary lenses of "resource managerialism, risk assessment, and/or recreation management" (Marcuse, 1972, p. 62; Luke, 1996, pp. 3-4).

These depoliticised understandings of Nature as a natural resource play an important role in positioning people as 'sustainable' subjects. Technoscientific ecoknowledge discourses are not 'inherently' apolitical, but as Luke (1996, p. 2, 2009, p. 130) argues, "economic performativity" tends to overshadow concerns for ecological preservation and so resource managerialists and environmental scientists have a tendency to view the natural environment "as a site of accumulated resources, which contains/holds 'stock' ... [, and] as a structure of vital processes, which dispenses/vends 'service"”. Within these performative eco-knowledge discourses, sustainability is transformed into an agenda of sustaining the yields of Nature's stock by monitoring its output levels, overseeing the "rate of increasing or decreasing demand", and "managing the scale of 
sustained use in more socially integrated conditions of production" (Luke, 2009c, p. 135, 2006b, p. 103). Once the natural environment has been turned into apolitical 'stock', sustainability discourses attempt to 'work out the details' of how to readjust individuals to fit into these understandings of the natural environment, which positions individuals as 'sustainable' subjects (Luke, 2005, p. 235, 1997a, p. 196). One way that this is achieved, for example, is through detailed examinations of people's energy use, waste management, and consumption patterns, which detect technical and economic inefficiencies (Luke, 1999a, p. 136).

This adjustment and regulation of the population through certain conceptions of sustainability is what Foucault (1978/2008b, p. 139) calls "bio-power" (Luke, 1999a, p. 137). Bio-power is a form of "power over life" that brings "life and its mechanisms into the realm of explicit calculations and made knowledge-power an agent of transformation of human life" (Foucault, 1978/2008b, pp. 139, 143). It brings life into the realm of power/knowledge through the "disciplines of the body" and the "regulations of the population" (Foucault, 1978/2008b, p. 139). The "disciplines of the body" is a procedure of power that centres on the idea that the body is a machine (Foucault, 1978/2008b, p. 139). As a machine, the body can be made useful and docile, or it can be integrated "into systems of efficient and economic controls" by disciplining it, optimising its capabilities, and extracting its forces (Foucault, 1978/2008b, p. 139). In contrast, rather than focusing on the body as a machine, the "regulations of a population" focuses on the "mechanics of life" and how "biological processes: propagation, births, mortality, the level of health, life expectancy and longevity", can be managed through various interventions and regulatory controls (Foucault, 1978/2008b, p. 139). 
The material existence of ideology. Ideology not only exists in an ideal or spiritual form, but is also materialised in rituals, practices, and institutions (Althusser, 1984, p. 44). This second dimension of ideology, as conceptualised by Zizek (1994, p. 63) and Louis Althusser (1984, p. 40), is ideology as belief, which refers to how ideology is externalised or materialised in rituals, and apparatuses and their practices. Belief is not only something that is interior or psychological; it is also materialised and embodied in people's activities, institutions, and in things, such as commodities (for example, money is an embodiment of social relations, not just an embodiment of wealth) (Zizek, 2008a, pp. 27-31). The externalisation of ideological belief can be seen in what Althusser (1984, p. 19) calls the "Ideological State Apparatuses". Ideological state apparatuses, such as religion, education, and the family, "function massively and predominantly by ideology" and "secondarily by repression, even if ultimately, but only ultimately, this is very attentuated and concealed, even symbolic" (Althusser, 1984, p. 19). This is in contrast to "the (Repressive) State Apparatus", such as the army and the police, which "functions massively and predominantly by repression (including physical repression), while functioning secondarily by ideology" (Althusser, 1984, p. 9). Althusser (1984, p. 43) argues that a person's belief is material because "ideas are material actions inserted into material practices governed by material rituals which are themselves defined by the material ideological apparatus from which derive the ideas of that subject ${ }^{\prime \prime}{ }^{6}$ The material existence of belief is an important dimension of ideology because it highlights how ideologies are generated and reproduced. For example, going to church and

\footnotetext{
${ }^{6}$ Althusser (1984, pp. 43-44) uses the term "material" to argue that "ideas", which refers to something that has "an ideal or spiritual existence", should be replaced with the terms "subject, consciousness, belief, actions ... practices, rituals, ideological apparatus" because they have an existence "that is inscribed in the actions of practices governed by rituals defined in the last instance by an ideological apparatus".
} 
following its rituals, according to Zizek (1994, pp. 65-66), is not simply the materialisation of religious belief, but is part of the mechanisms that produce religious belief. By carrying out the "material rituals" that are part of the ideological state apparatuses, such as attending mass, individuals recognise themselves as religious subjects (McLennan, Molina, \& Peters, 1978, p. 96). Also, the material existence of ideology, says Zizek (1997, p. 4), helps reveal "inherent antagonisms which the explicit formulation of ideology cannot afford to acknowledge". Recycling as a means for achieving sustainability, for example, reveals the antagonism between over-consumption and environmental degradation.

The material existence of ideology is an important idea that sheds light on how, for example, individualised and neo-liberal sustainability practices remove a corporation's responsibility for being sustainable. Corporate sustainability practices, such as office recycling programmes, can be analysed as the material expression of a business's belief that sustainability is an individual problem, rather than a structural problem, which can be solved through individual 'free choice'. Analysed as a material expression of belief, corporate sustainability practices can be interpreted as an example of what Zizek (1998, p. 143) calls "interpassivity", where someone or something can be “active through another subject who does the job for me". For example, even though individualised sustainability practices may not achieve economic or environmental sustainability, businesses can argue that "objectively, through the medium of the other" (their sustainability practices), they were 'sustainable' (Zizek, 2008a, p. 33).

The material existence of ideology is similar to what Foucault (1977/1991a, p. 215) calls the procedures of disciplinary power. Like ideological apparatuses, disciplinary 
power does not function through violence and only functions through repression or punishment secondarily (Foucault, 1977/1991a, pp. 137, 180). However, unlike ideological apparatuses, which operate secondarily through disciplinary techniques, disciplinary power operates primarily through, for example, observations, judgements and examinations, which not only punish, but also classify, qualify, and reward (Foucault, 1977/1991a, p. 170). Rather than functioning primarily through ideology, Zizek (2008b, p. 299) argues that Foucault's (1977/1991a) idea of disciplinary power can bypass ideological "subjectivization" ("how people relate to their conditions of existence") by operating directly on individual human bodies. Individual subjects, according to Foucault (1982, p. 777), are not hailed by an ideology, but are created as subjects through disciplinary practices or "dividing practices". However, disciplinary power only bypasses ideological subjectivisation when it operates on people who are already subjects, such as a prisoner, school student or military officer, which is why I focus on how disciplinary power materialises ideological beliefs, rather than bypassing them (Foucault, 1977/1991a, p. 26). For example, following religious rituals 'trains' and 'makes' religious subjects; it is not simply the expression of a person's religious belief (Foucault, 1977/1991a, p. 170; Zizek, 1994, pp. 65-66). More precisely, religious rituals do not exist below or alongside power; rituals are procedures of power that "establish, maintain, and transform mechanisms of power" (Foucault, 2007, p. 2).

From Foucault's perspective, rather than religious rituals (such as prayer) being the materialisation of religious ideological belief, religious rituals are disciplinary practices that 'train' and 'make' individuals into religious subjects and objectivise them as religious subjects by dividing them from non-religious subjects (Foucault, 1977/1991a, 
p. 170, 1982, p. 778). Foucault (1978/2008b, p. 94) does not frame disciplinary power exclusively in terms of ideology because this would mean framing power in terms of something that can be acquired or seized. However, although there are differences between the material existence of ideology and the procedures of disciplinary power, when disciplinary power is situated within the context of how ideology functions, disciplinary practices are material beliefs or procedures that, when "taken over" by an institution or a "pre-existing authority", performatively reproduce an ideological doctrine (Foucault, 1977/1991a, p. 215; Zizek, 1994, pp. 66-67).

The material existence of ideology and governmentality. Sustainability narratives, as the material expression of ideology, govern by objectivising individuals as ‘sustainable' subjects through disciplinary practices that divide 'sustainable' subjects from 'unsustainable' subjects (Foucault, 1982, p. 778). According to Foucault (1977/1991a, pp. 137-138), disciplinary power is a general formula of domination that "produces subjected and practised bodies, 'docile' bodies". It is "a whole set of instruments, techniques, procedures, levels of application, targets [that] ... may be taken over" and used by an institution or authority to control "the operations of the body" and the "soul"7 (Foucault, 1977/1991a, pp. 16, 137, 215). Disciplinary power targets individuals' "movements, gestures, attitudes, rapidity" with the aim of regulating and “ordering human multiplicities” (Foucault, 1977/1991a, pp. 137, 218). Techniques or procedures like the use of surveillance, timetabling, hierarchies, judgements, rewards, and punishments help to produce 'docile' bodies (Foucault, 1977/1991a, pp. 135-170).

\footnotetext{
${ }^{7}$ According to Barry Smart (1983, p. 109), "soul” can be "conceptualised in terms of psyche, subjectivity, personality, consciousness, and individuality".
} 
However, rather than simply controlling and correcting individuals, disciplinary power 'produces' individuals as subjects and objects of knowledge; it is intertwined with various skills and forms of knowledge (Foucault, 1977/1991a, pp. 27, 194). As Foucault (1977/1991a, p. 27) argues, "power and knowledge directly imply one another; . . . there is no power relations without the correlative constitution of a field of knowledge, nor any knowledge that does not presuppose and constitute at the same time power relations". Disciplinary practices, therefore, increase the skill and knowledge of the individual and can prepare them for some form of function, such as a worker or military officer (Danaher, Schirato, \& Webb, 2000, p. 50; Foucault, 1977/1991a, p. 210).

One of the main forms of disciplinary power that positions and objectifies individuals as subjects and objects of knowledge, is what Foucault (1977/1991a, p. 183) calls "normalizing judgement" or normalisation. Disciplinary practices normalise by setting a required level that must be reached before the task is carried out 'correctly', or by punishing those who do not conform, which helps establish a 'normal' way of carrying out the task (Foucault, 1977/1991a, p. 179). When the 'normal' way of carrying out a task has been set and when a large number of people carry out the task, people become ranked or graded in terms of how they "measure up to the rule" (Foucault, 1977/1991a, pp. 178, 181). John S. Ransom (1997, p. 48) argues that once these norms are established they contribute "to a conception of a "natural" (thus normal) human body".

By helping to create a conception of a 'normal' human body, normalising disciplinary practices help form a set of "truths" about human beings by differentiating people according to the categories of normal and abnormal, or placing them on a scale between normal and abnormal (Ransom, 1997, p. 48; Foucault, 1977/1991a, p. 181). 
When there is a 'normal' way of carrying out a task, an individual's body, 'nature', potential, and 'value' are turned into objects that can be measured, compared, and judged (Foucault, 1977/1991a, p. 181). For example, as a practice of consuming 'sustainably', consuming 'green' products could be interpreted as a disciplinary practice that positions individual consumers as either 'sustainable' or 'unsustainable'.

When the rituals and practices of sustainability (such as consuming 'green' products) are analysed as the materialisation of individualised and neo-liberal ideological beliefs, consuming 'green' products is a form of environmentality, which, like governmentality, establishes and enforces "the right disposition of things" ${ }^{\text {" }}$ by 'training' and 'making' individuals into 'sustainable' consumers (Luke 1995/2006a, p. 264; Foucault, 1991b, p. 93, 1977/1991a, p. 180). The generation of "particular assumptions, codes and procedures" or "truths" about sustainability within eco-knowledge discourses also helps create "truths" about human beings by stating, either explicitly or implicitly, what forms of consumption and ways of living are normal or desirable (Luke, 1995/2006a, p. 267). When these "truths" about sustainable consumption and living are mobilised through the normalising procedures of "environmentalized" disciplinary power, governments, institutions, or businesses are able to enforce their own "codes" of sustainability by encouraging people to become 'sustainable' subjects, which performatively reproduce their ideological doctrines of sustainability (Luke, 1995/2006a, pp. 264, 267). The ritual of consuming 'green' products, for example, reproduces

\footnotetext{
8 "Things" refers to people in their relations "with those other things which are wealth, resources, means of subsistence, the territory with its specific qualities, climate, irrigation, fertility, etc.; . . customs, habits, ways of acting and thinking, etc.; . . . accidents and misfortunes such as famine, epidemics, death etc." (Foucault, 1991b, p. 93).
} 
sustainability doctrines by creating 'sustainable' subjects who demand 'sustainable' goods and services.

Ideology and the subject. Although the material existence of ideology and ideology as a doctrine are crucial dimensions in the reproduction of "existing social relations", this reproduction, according to Althusser (1984, p. 44), "is only made possible by the subject". The importance of the subject within theories of ideology can be seen in Zizek's (1994, p. 63, 2008a, p. 42) idea of ideology as a ritual, which focuses on how ideology is operative in people's “"spontaneous' (self-)experience” as subjects, whether it is conscious or unconscious. Althusser (1984, p. 47) elaborates on the importance of ideology and subjectivity when he argues that "all ideology hails or interpellates concrete individuals as concrete subjects" in the "name of the Subject" by either 'recruiting' "subjects among the individuals" or 'transforming' "individuals into subjects" (McLennan et al., 1978, p. 96). Ideology either recruits subjects or interpellates individuals as subjects because people believe, and recognise, that they are subjected to it; it addresses people as subjects, whether it is conscious or unconscious recognition (Althusser, 1994, p. 131; Zizek, 2008a, p. 42). What is unique, according to Zizek (1994, p. 68), about this dimension of ideology is that it is not a doctrine "nor ideology in its material existence", but an "elusive network of implicit, quasi-'spontaneous' presuppositions and attitudes that form an irreducible moment of the reproduction of 'non-ideological' (economic, legal, political, sexual ...) practices”.

Rather than focusing on how people are made into subjects through ideological interpellation, Foucault (1982, pp. 781-782) focuses on how individuals are made into 
subjects ${ }^{9}$ through certain techniques of power or "mechanisms of subjection". As outlined above, people can be turned into subjects through objectifying forms of knowledge, and disciplinary dividing practices (Foucault, 1982, pp. 777-778). However, people also turn themselves into subjects through "practices of the self", which are social and cultural models for "acceptable" forms of social conduct (Foucault, 2000b, pp. 285, 291). Instead of focusing on how people either believe in or recognise that they are subjected to an ideology, Foucault (1988, p. 18) analyses how people are either made into subjects or turn themselves into subjects through the various practices or technologies of the self. Luke (1999a, p. 137) also adds the important point that although people are either made into subjects or turn themselves into subjects, certain truth regimes always create criteria for what forms of 'selfness' will be privileged. In terms of individualised sustainability discourses, for example, people can be subjected to its "codes of sustainability" that are developed and enforced by state agencies or they can turn themselves into "self-directed ecological subject[s]", but either way individualised sustainability narratives "[draw] up criteria for what sort of 'selfness' will be privileged" (Luke, 1999a, p. 137).

While Foucault's (1988) and Althusser's (1984) theories of subjectivity are similar in the sense that they both focus on how individuals become subjects through either technologies of the self or ideological interpellation, their ideas do not account for why people do something even if they do not believe in it, which is why I utilise Zizek's (2008a, p. 44) integration of Lacan's idea of fantasy and enjoyment with ideological interpellation to analyse how sustainability discourses function ideologically. Although

\footnotetext{
${ }^{9}$ According to Foucault (1982, p. 781), "there are two meanings of the word "subject": subject to someone else by control and dependence; and tied to his own identity by a conscience or self-knowledge. Both meanings suggest a form of power which subjugates and makes subject to".
} 
Foucault (1980a, p. 59, 1980b, p. 118) discusses how power "produces effects at the level of desire - and also at the level of knowledge", he limits his discussion of ideology to the realm of knowledge: that is, how it produces "effects of truth". By doing this, Foucault overlooks Zizek's (2008a, pp. 29-30) idea that ideological illusion structures and supports social reality, which helps explain how ideology can operate without conscious belief.

Unlike Foucault, Althusser (1984) does incorporate psychoanalytic ideas into his theory of ideology. However, according to Zizek (2008a, p. 43), he only discusses how ideology is “'internalized' into the ideological experience of Meaning and Truth”. According to Zizek (2008a, p. 43), this “'internalization', by structural necessity, never fully succeeds ..." and it is this failure of full internalisation that, ". . far from hindering the full submission of the subject to the ideological command, is the very condition of it". People may encounter contradictions between what an ideology states and what is experienced in everyday life, but ideology does not rely on encouraging people to see the world 'objectively' and 'rationally'; it grasps people through irrational enjoyment and fantasy (Zizek, 2008a, p. 48; J. Dean, 2006, p. 8). In other words, ideology is never fully internalised because, for ideology to be effective as a support for social 'reality', it needs to mask and offer an escape from some traumatic antagonism that cannot be symbolised (Zizek, 2008a, p. 45). As Jodi Dean (2006, p. 12) argues, ideological "fantasy keeps open the possibility of enjoyment by telling us why we are not really enjoying". For example, individualised sustainability narratives may offer an escape from the traumatic antagonism between global capitalism's 'unsustainable' growth and environmental degradation, not by telling people to think about the connections between capitalism and environmental degradation, but by telling people why they are not really enjoying 
sustainable capitalism (J. Dean, 2006, p. 12). They tell people, for example, that capitalism can become 'sustainable' if people start driving hybrid vehicles and consuming 'eco-friendly' products and services. Therefore, by following the fantasy of consuming 'sustainably' to keep open the possibility of enjoying sustainable capitalism, people become anchored to the ideology that sustainability can be solved through the actions of individuals (J. Dean, 2006, pp. 12-13).

The strength of the idea that ideology is a ritual is that, when it is conceptualised in terms of Zizek's (2008a, p. 44) idea of ideological fantasy, it can account for how ideology can function without people consciously believing in it. One of the problems associated with ideology in its material form and ideology as a doctrine is that it does not, for example, guarantee the reproduction of individualised and neo-liberal understandings of the environment and sustainability; it seems likely that people would not seriously believe that individualised sustainability discourses are an important part of securing sustainability, whether it is environmental or economic (Zizek, 1994, p. 68). Although individualised understandings of sustainability might not be convincing as a doctrine or as a practice, they are still able to function ideologically because people still carry out these 'sustainable' practices, such as recycling, switching off lights, or consuming water from an 'ecologically friendly' plastic bottle, which helps reproduce the hegemony of neo-liberal and individualised understandings of sustainability. Indeed, Zizek (2008a, p. 43) argues that the gap between ideology and its internalisation is important for how ideology functions even if people do not consciously believe in it.

This gap between ideology and its internalisation, which enables people to carry out ideological rituals without believing in them, is what Zizek (2008a, p. 44) calls 
ideological fantasy. I focus on cynicism as a form of ideology and ideological fantasy to explore the idea that people carry out the rituals of an ideology even if they do not consciously believe in it (Zizek, 2008a, p. 42). According to Zizek (2008a, p. 30), the idea of cynical distance seems to suggest that people now live in post-ideological societies, where "people no longer believe in ideological truth; they do not take ideological propositions seriously". In contrast, however, Zizek (2008a, p. 30) argues that "cynical distance is just one way - one of many ways - to blind ourselves to the structuring power of ideological fantasy: even if we do not take things seriously, even if we keep an ironical distance, we are still doing them". People are able to account for the power interests that lie behind an ideology, but are still able to find reasons not to reject it (Zizek, 2008a, p. 26). In other words, people " know that, in their activity, they are following an illusion, but still, they are doing it"”, which goes against Marx's definition of ideology as false consciousness and his phrase that "they do not know it, but they are doing it" (Zizek, 2008a, pp. 29-30). Rather than an illusion being present only in an ideological doctrine, illusion is also contained in people's beliefs, rituals, and practices; "it is already on the side of reality itself" (Zizek, 2008a, p. 30). Zizek (2008a, pp. 29-30) argues that people's "social reality itself, their activity, is guided by an illusion" or an (unconscious) ideological fantasy, which is in contrast to the idea that ideological illusion is only a distorted form of knowledge. In other words, "ideology is already at work in everything we experience as 'reality"' and so people's rituals and actions are not outside of ideology (Zizek, 1994, p. 70).

The ideological illusions that are contained within social reality and activity are what Zizek (2008a, p. 27) calls ideological fantasies. According to Zizek (2008a, p. 45), 
ideology, which includes people's social activities and what they experience as reality, is a "fantasy-construction" that supports and structures people's 'reality'. This does not mean that fantasy simply masks the 'true' nature of a situation - fantasy "creates what it purports to conceal" (Zizek, 1997, p. 7). Social 'reality', such as people's relationship with Nature, does not exist outside of the discourses and meanings that construct this relationship, and it is social-ideological fantasies that stage these relationships and construct visions of them that do exist (Luke, 1995/2006a, p. 257; Zizek, 2008a, pp. 141142). More precisely, ideological fantasy fills "out the empty space of a fundamental impossibility, a screen masking a void" (Zizek, 2008a, p. 141).

Cynical distance, which I will use to provide a lens through which to analyse sustainability discourses, underlies my suggestion that people follow the rituals associated with individualised sustainability discourses while not seriously believing in them. One reason why people might do something without believing in it is that consuming without risk is part of the neo-liberal fantasy of the 'free individual' who is responsible for the choices they make (J. Dean, 2008, p. 47). People carry out the rituals associated with individualised forms of sustainability because it is part of the ideological fantasy associated with the culture of neo-liberalism, that is, individual 'free choice' (J. Dean, 2008, p. 47). Although this seems paradoxical, Zizek's (2006, p. 238) example of people who have a Christmas tree in their house without believing in Santa Claus highlights how cynical distance functions as ideology. Individualised sustainability discourses, when analysed as a form of cynicism, encourage individuals to live and consume according to neo-liberal understandings of the environment and sustainability by emphasising individual responsibility and freedom. People consume 'sustainably', 
even though they do not believe in it, because neo-liberal sustainability discourses, for example, organise enjoyment through the fantasy of individual 'free choice' and responsibility (J. Dean, 2008, pp. 47, 52). Rather than consuming 'sustainably' to protect the environment, people also consume 'sustainably' because they are responsible subjects who freely choice to do so.

Ideology, the subject, and governmentality. Individual responsibility is manifested in sustainability discourses in the form of 'risk-free' consumption or consumption without risk. "Risk-free consumption" is a paradoxical term that underpins individualised sustainability discourses. Consumption, when it is nominally defined, means to "devour" or "use completely", and it can also mean to "destroy", "waste", or "devastate" (Luke, 1997b, p. 15). Risk-free consumption, therefore, is paradoxical in the sense that the idea of risk is an intrinsic part of consumption. In other words, to remove risk from the act of consumption is similar to Zizek’s (2006, p. 239) argument that in contemporary societies there is a tendency to remove the malignant properties from almost everything. The irony of utilising the idea of risk-free consumption as a method of securing environmental sustainability is that it relies on the very thing (consumption) that is helping cause environmental degradation (Zizek , 2006, p. 240, 2008b, p. 6).

This tendency to remove the risky properties from something is part of the development of what Beck (1992) calls the "risk society". Beck's (1992, p. 151) idea of the risk society is underpinned by his idea of "reflexive modernization". Beck (1992, p. 12) argues that in industrial societies, wealth production was the primary form of risk, whereas in risk societies the production of risks dominates "the 'logic' of wealth production". That is to say, modernisation, as Beck (1992, p. 19) argues, “. . . is 
becoming reflexive"; it is attempting to limit and distribute risks "so that they neither hamper the modernization process nor exceed the limits of that which is 'tolerable' ecologically, medically, psychologically and socially". The risks that Beck (1992, p. 22) is mainly referring to here are those of radioactivity, toxins, and pollutants, which can have local, national, or global consequences.

The risks, hazards, and insecurities that arise within risk societies are different from earlier industrial societies, in the sense that they are "induced and introduced by modernization itself"; they "are consequences which relate to the threatening force of modernization and to its globalization of doubt” (Beck, 1992, p. 21). In earlier industrial societies, Beck (1992, p. 21) argues that most risks and hazards were regional or national in scale, such as water pollution, and were connected with the "undersupply of hygienic technology". Also, most risks could be detected through sensory perception (Beck, 1992, p. 21). In contrast, contemporary risks and hazards tend to be global in scale, such as deforestation from industrialisation or radioactivity, and "have their basis in industrial overproduction" (Beck, 1992, pp. 21-23). Also, contemporary risks are not always detectable through sensory perception, which means that people cannot predict the level of risk or harm that they may cause because they "only exist in terms of the (scientific or anti-scientific) knowledge about them" (Beck, 1992, p. 23).

While these contemporary global risks are environmental, ecological, and biological, Beck (1992, p. 87) claims that "they overlap with social, biographical, and cultural risks and insecurities", which he calls "individualization". Risk societies are not only characterised by their reflexive attempt to manage the manufactured risks they produce, but are also characterised by a shift towards "institutionalised individualism" or 
individualisation (Beck \& Beck-Gernsheim, 2002, p. xxi). Individualisation is different from neo-liberal individualisation or individual 'free choice' in the sense that it is not 'freely chosen' (Beck \& Beck-Gernsheim, 2002, p. xxi). For example, Beck and Elisabeth Beck-Gernsheim (2002, p. xxii) argue that social, political, and civil rights as well as education and training are "geared to the individual and not to the group".

Beck's idea of the risk society, which focuses on the nature of contemporary risks and the development of institutionalised individualism, provides a possible social underpinning for the idea of risk-free consumption (Beck \& Beck-Gernsheim, 2002, p. xxi). The idea of risk-free consumption can be understood through Zizek's (2006, pp. 239-240) idea of tolerance without intrusion. According to Zizek (2006, p. 238), tolerance without intrusion revolves around the idea of "decaffeinated belief", or "the prohibition to embrace a belief with full passion". Consumption in a 'risk society' is structured according to tolerance without intrusion: that is, people can consume without constraint so long as it does not have a negative environmental impact. Zizek (2004, p. 508) suggests that this belief in tolerance without intrusion can be seen as a new form of hedonism, that is, pleasure with constraint. According to Zizek (2004, p. 508), "the very thing which causes damage should already be the medicine": that is, "action and reaction" coincide and so people can consume without risk. For example, rather than consuming coffee in moderation or no coffee at all, people can consume decaffeinated coffee without the risks associated with caffeine consumption (Zizek, 2004, pp. 507-508). In terms of sustainable consumption, if a power company produces power 'sustainably' from hydroelectricity, then the individual consumer can consume power without fear of 
the environmental damage that is associated with other 'unsustainable' forms of power production, such as fossil fuel power production.

When the idea of risk-free consumption is applied to sustainability narratives, it can be analysed as a form of environmentality that helps manage "anonymous masses of population" by normalising sustainability as an individualised phenomena through the governmentalisation of the self (Luke, 1990, p. 243). Sustainability narratives do this by focusing on consumption as a technique or "technology" of governing the "consuming self" (Barnett, Cloke, Clarke, \& Malpass, 2005, p. 8). Governing the self is not a coercive practice, but a practice of self-formation and transformation, which involves taking care of the self (Foucault, 2000b, p. 282). Taking care of and knowing the self is what Foucault (1988, p. 18) calls “technologies of the self", which "permit individuals to effect by their own means or with the help of others a certain number of operations on their own bodies and souls, thoughts, conduct, and way of being, so as to transform themselves in order to attain a certain state of happiness, purity, wisdom, perfection, or immortality". From the perspective of governmentality, techniques or technologies of the self can be interpreted as "the government of the self by oneself in its articulation with relations with others" (Foucault, 2000a, p. 88). When technologies of the self are situated within sustainability narratives, techniques for being a 'sustainable' consumer are prescriptions for how to live in a society operating under the "systemic requirements of ecology" (Foucault, 2000a, p. 88; Luke, 1999b, p. 122).

Risk-free consumption narratives, when analysed as a way of knowing the self, attempt to govern how people live by creating a way of knowing how to consume 'sustainably', which also helps create a way of knowing how to take care of the self 
(Foucault, 1988, p. 18). As Foucault (2000b, p. 285) argues, knowledge of the self is not only knowing how to take care of the self, but also knowing the various "rules of acceptable conduct or of principles that are both truths and prescriptions". When individualised sustainability discourses prescribe 'sustainable' ways to consume and live, they do not determine 'sustainable' forms of subjectivities, but encourage people to identify or experience themselves through various rules, "capacities, qualities and statuses" (M. Dean, 2010, pp. 43-44). Consuming in ways that have a minimal environmental impact, for example, is a way of gaining "mastery over oneself" or identifying as a 'sustainable' consumer (Foucault, 1988, p. 35, 2000b, p. 285).

Foucault's (2000b, p. 285) concept of technologies of the self, highlights how the practices and narratives of consuming 'sustainably', have the effect of normalising sustainability as an individualised phenomena through the techniques that people use to care for and know the self. However, Zizek's (2008a) idea of ideological fantasy adds another dimension by highlighting how individualised sustainability rituals and practices can be carried out without the conscious belief that they will achieve environmental sustainability; a consideration absent from Foucault's approach. Although people may form 'sustainable' subjectivities, it is likely that they may not be consciously forming them through prohibitive technologies of the self that are encouraged within individualised sustainability discourses, such as walking rather than driving a vehicle (Foucault, 1988, p. 18). Zizek (2008b, p. 451) argues that rather than only being formed through symbolic norms of acceptable social conduct, techniques of the self can also be formed through conscious or unconscious "imaginary ideals". People take care of themselves not only through the various rules and prescriptions of acceptable conduct 
(such as walking rather than driving a vehicle), what Zizek (2008b, p. 451) calls

"symbolic prohibitive norms", but also through imaginary ideals, such as social success or 'green' consumerism.

Zizek (2008a, p. 43) approaches the problem of how people transform themselves through his idea that not believing in an ideology is an important dimension of how people are subjected to it, which provides a way of theorising how ideology can be active in people's experiences, beliefs, rituals, and practices without them consciously believing it. One way that this happens is through Zizek's (2008a) idea of cynicism, enjoyment ${ }^{10}$, and ideological fantasy. As cynical subjects, people know that recycling or consuming water from an 'eco-bottle' will not help a society achieve sustainability. However, they do it anyway because the ideological fantasy of consuming without risk keeps alive the possibility of enjoying a life free from risk by telling people that sustainability can be achieved if people were to change their 'unsustainable', risky consumption habits to 'sustainable' consumption habits (J. Dean, 2006, p. 12). What people forget or do not know, according to Zizek (2008a, p. 30), is that their social activity and their relationship to 'reality' is guided and structured by ideological fantasy.

\section{Methodological Framework}

With this framework established, I now discuss how I will employ my integration of ideology with Foucault's conception of governmentality and power by outlining and discussing Fairclough's (1992) critical discourse analysis. Fairclough's critical discourse analysis is an appropriate methodological tool to employ in my analysis of sustainability discourses because it incorporates Foucaultian discourse analysis and ideology critique.

\footnotetext{
${ }^{10}$ According to J. Dean (2006, p. 4), "enjoyment (jouissance) refers to an excessive pleasure and pain, to the something extra that twists pleasure into a fascinating, even unbearable intensity"; it is "this extra, this excess beyond the given, measurable, rational, and useful".
} 
Before I outline Fairclough's critical discourse analysis, I discuss how it is underpinned by his social theory of discourse.

Fairclough (1992, p. 39) blends Foucault's discourse analysis with ideology critique to create his own social theory of discourse, which underpins his textuallyoriented approach to critical discourse analysis. Fairclough's (1992, pp. 62, 73) social theory of discourse is underpinned by his idea that discourse is a social practice. Like Foucault, Fairclough (1992, p. 56) focuses on the discursive nature of social practices. He argues that discourse is a form of social practice ${ }^{11}$ that not only shapes "situations, institutions and social structures", but is also shaped by them (Fairclough \& Wodak, 1997, p. 258). Discursive practices, when analysed as ideological doctrines, can either sustain, reproduce, or transform the social world and they also reflect a "deeper social reality" (institutions, practices, and identities that were discursive practices, but have now become reified into "real, material social structures" that cannot simply be changed through discourse) (Fairclough \& Wodak, 1997, p. 258; Fairclough, 1992, p. 66). For example, relationships between people and the environment are both discursively and non-discursively constructed. The relationships that exist between people and the environment are dependent on what is meaningful, but non-discursive, material conditions, such as existing relationships that have been "reified into institutions and practices", place people into these relationships as well (Luke, 1995/2006a, p. 257; Fairclough, 1992, pp. 65-66).

By focusing on how discourse can both maintain and transform existing social practices, Fairclough (2001, p. 229) provides an understanding of discourse as a political

\footnotetext{
${ }^{11}$ Social practices refer to either discursive practices (practices that function according to the logic of a discourse) or non-discursive practices (practices that do not function according to the logic of a discourse) (Jorgensen \& Phillips, 2002, pp. 18-19).
} 
practice that is intertwined with power, ideology ${ }^{12}$, hegemony ${ }^{13}$, and social change (Fairclough \& Wodak, 1997, p. 258). As a discursive form of power, discourse can produce, reproduce, and transform relations of domination or existing social relationships and institutions by naturalising, sustaining, or changing significations of the world that are established in power relations (Fairclough, 1992, pp. 67, 87). For example, individualised sustainability discourses potentially environmentalise people's lives, which changes how people live and consume.

Fairclough's (1992) idea that discourse is a political and social practice, underpins his conceptualisation of discourse. As a concept, discourse is used in a variety of academic disciplines and theoretical standpoints and so it can be defined in a number of different ways (Fairclough, 1992, p. 3). Fairclough (1992, p. 42) defines discourse as “a practice not just of representing the world, but of signifying the world, constituting and constructing the world in meaning". Discourse is a practice because it embodies a whole range of human activities, such as certain ways of "behaving, interacting, valuing, thinking, believing, speaking, . . . reading, and writing" (Gee as cited in Locke, 2004, p. 7). Similarly, Fairclough's (1992, p. 42) statement, "constituting and constructing the world in meaning", refers to the idea that discourse is in an active relationship with the world; it does not simply refer "to objects which are taken to be given in reality". For example, sustainability discourses embody the view that the natural environment is relatively fragile (Barry, 2007, p. 44; Milton, 1996, p. 124).

\footnotetext{
${ }^{12}$ Fairclough (1992, p. 87) defines ideology as: "significations/constructions of reality (the physical world, social relations, social identities), which are built into various dimensions of the forms/meanings of discursive practices, and which contribute to the production, reproduction or transformation or relations of domination".

${ }^{13}$ In general, hegemony is a form of power that depends on consent rather than coercion (Fairclough, 2001, p. 232). More specifically, Fairclough (1992, p. 92) defines hegemony as: "constructing alliances, and integrating rather than simply dominating subordinate classes, through concessions or through ideological means, to win their consent".
} 
Faircloughian critical discourse analysis: Method. Fairclough's (1992, p. 72) social theory of discourse, which regards language as a social and political practice, underpins his "three-dimensional conception of discourse". Fairclough (1992, p. 72) states that discourse is made up of three interrelated dimensions: text, discursive practice, and social practice. Discourse as text refers to writing, speech, or visual images (Jorgensen \& Phillips, 2002, p. 68). Whereas, discursive practice refers to how the text is produced, distributed, and consumed (Fairclough, 1992, p. 71). Social practice refers to the broader context in which the text was produced. Moreover, it refers to how a text is connected to power and ideology (Fairclough, 1992, p. 86).

Each dimension of discourse is connected to a different type of analysis, although analysis can overlap because there is no sharp distinction between the three dimensions (Fairclough, 1992, p. 74). Discursive practice involves focusing on how the text is produced, how it is distributed, and how it is consumed. Also, according to Fairclough (1992, p. 232), discursive practice involves specifying "what discourse types are drawn upon in the discourse sample under analysis". Fairclough (1992, p. 232) calls this "interdiscursivity". For example, I will discuss the connections between individualised sustainability discourses and neo-liberal discourses.

The analysis of a text involves exploring its form, and interpreting the "meaning potentials" of words and the wording of meanings (Fairclough, 1995, p. 57, 1992, p. 186). Fairclough (1992, pp. 137, 169) distinguishes between forms of text analysis that focus on the construction of social relations (the "interpersonal function of language"), and forms of text analysis that focus on the construction of social reality (the "ideational function of language"). Because I am not focusing on the interpersonal function of 
language, I will be utilising the tools that can be used to analyse the construction of social reality within discourse, although there are some tools that can be used within both approaches (Fairclough, 1992, p. 137).

To analyse linguistic and visual texts the researcher can draw on a number of tools that Fairclough recommends. The main tools that I will be using to analyse sustainability discourses include, but are not limited to, the following. First, "connectives and argumentation" are tools that relate to the cohesion and structure of a text (Fairclough, 1992, p. 171; Locke, 2004, p. 48). By analysing the text's structure and cohesion the researcher is able to find what type of argument is being used (Fairclough, 1992, p. 171). Second, "transitivity and theme" are tools that are connected with grammar (Fairclough, 1992, p. 177; Locke, 2004, p. 48). "Transitivity" refers to the ideological consequences of using certain words, sentence structures, and images (Jorgensen \& Phillips, 2002, p. 83). Whereas, "theme" refers to the analysis of clauses: that is to say, analysing a theme involves examining the textual function of a clause and how it structures 'information', which can reveal any rhetorical strategies and common sense assumptions within a text (Fairclough, 1992, p. 183). Third, "word meaning" and “wording" are related to vocabulary (Fairclough, 1992, p. 185; Locke, 2004, p. 50). The researcher discusses the various meanings of a word and how meanings have been 'worded' (Fairclough, 1992, p. 185). At the same time I will also be identifying the visual signs within sustainability narratives and discussing what they signify. Finally, I will discuss how texts are signified through certain metaphors (Fairclough, 1992, p. 194).

The analysis of social practices involves contextualising the text and discursive practices (Jorgensen \& Phillips, 2002, p. 86). There are three main steps involved in 
contextualising the text and discursive practices. First, the researcher identifies the orders of discourse that are drawn on within a discursive practice (Fairclough, 1992, p. 237). An "order of discourse" is a Foucaultian term that Fairclough (1992, p. 43) uses to describe the discourses that are used within a social domain or field (such as business) and the relationships between them (Jorgensen \& Phillips, 2002, p. 72). Regarding sustainability discourses, I will discus how individualised sustainability discourses draw on neo-liberal understandings of the environment. Second, the researcher discusses the ideological and political effects of discourse (Fairclough, 1992, p. 238). For example, I will discuss how sustainability discourses depoliticise environmental phenomena. Finally, the researcher draws on social theories to discuss the wider social context that constitutes the discursive practice (Fairclough, 1992, p. 237). Here I analyse the connections between sustainability discourses and the environmentalisation of everyday life.

Spheres of analysis. Because I focus on the governmentalisation of sustainability, I will be analysing New Zealand-based civil society, state, and market sustainability narratives using judgemental or purposive sampling (Babbie, 2007, p. 184). More specifically, I will be analysing the MfE, Genesis Energy, and Greenpeace's sustainability narratives. I have selected these sustainability narratives to explore the relationships between the practices and narratives of sustainability that are generated within the spheres of the state, market, and civil society. Moreover, I analyse state, market, and civil society narratives to discuss the relationships between these three spheres.

Within the state sphere, there are a large number of sustainability narratives that range from local council sustainable city narratives, such as the Auckland Sustainable 
Cities Programme (2006), which was established by the New Zealand government's (MfE, 2003) Sustainable Development Programme of Action, to the Ministry of Education's (n.d.) Education for Sustainability initiative. I focus here on the New Zealand government's six sustainability initiatives, which were announced in February 2007 (MfE, 2010a). The six sustainability initiatives focus on "helping households towards sustainability", "business partnerships for sustainability", eco-verification, government procurement practices, developing a Carbon Neutral Public Service Programme, and minimising and managing waste (MfE, 2007b, 2009i, 2009j). I analyse these six initiatives to explore the governmentalisation of sustainability.

Like the New Zealand government's sustainability narratives, there are numerous sustainability narratives that are generated within the sphere of the market. Market-based sustainability narratives appear to be used by businesses to highlight how their products and services are environmentally 'sustainable', such as Charlie's (2010) "Eco-Bottle", or how their business practices are environmentally 'sustainable', such as buying locally sourced products as part of their procurement strategy. As well as highlighting how their business practices are environmentally 'sustainable', some market sustainability narratives encourage people to live and consume 'sustainably'. I focus here on Genesis Energy's (2010f, 2010g) sustainability narratives that encourage people to consume ‘sustainably'.

I have chosen to analyse Genesis Energy's television advertisements because they explicitly encourage a broad range of people to environmentalise their everyday lives, whereas their websites appear to only target existing or potential Genesis Energy customers, although their websites are also included in my analysis. Genesis Energy's 
television advertisements address multiple audiences: people who are interested in climate change and sustainability (the 'addressee' or "those directly addressed"); Genesis Energy's existing and future customers (the 'hearers' or "those not addressed directly"); and people who view the advertisement, but are not Genesis Energy customers or interested in environmental issues (the 'overhearers' or 'those who do not constitute part of the 'official' audience, but are known to be de facto consumers") (Fairclough, 1992, pp. 79-80).

The governmentalisation of sustainability also appears to cut across the practices and narratives that are generated within civil society. I analyse civil society sustainability narratives to explore how and if they differ from the sustainability narratives that are produced within spheres of the state and the market. There are a number of civil society sustainability narratives that encourage people to buy from environmentally 'sustainable' businesses and to consume and live 'sustainably'. For example, Annmaree Kane and Christina Neubert's (2008) book, Living Green: The New Zealand Hand Bookfor an Eco-Friendly, Toxin Free, Sustainable Life, and Good magazine's (2010), The Good Shopping Handbook, can be analysed as sustainability narratives. However, I focus on Greenpeace's sustainability narrative because their narrative appears to be in conflict with the MfE's and Genesis Energy's individualised sustainability narratives. Because Greenpeace's sustainability narrative appears to focus on the connection between sustainability, climate change, and business practices, rather than encouraging people to consume and live 'sustainably', I will discuss how it differs from state and market narratives, and if there are any similarities between the three. 
To summarise, I have selected three state, market, and civil society narratives that appear to construct governmentalised and individualised understandings of how to live and consume 'sustainably'. I blended Zizek's notion of ideology, Luke's concept of environmentality, and Foucault's conceptions of power and governmentality to create a framework for analysing how sustainability narratives function as governmentality. As an ideological doctrine, I focused on how sustainability narratives generate depoliticised understandings of sustainability that position individuals as 'sustainable' subjects. I then discussed how everyday rituals and practices of living and consuming 'sustainably' performatively reproduce individualised and neo-liberal ideological doctrines of sustainability. Having focused on the idea that individualised understandings of sustainability are potentially normalised through disciplinary practices and technologies of the self, I then explored how individualised sustainability rituals and practices can be carried out without the conscious belief that they will achieve environmental sustainability. I employ this theoretical framework in the following three chapters by analysing the MfE, Genesis Energy, and Greenpeace's sustainability narratives. 


\section{Chapter Three: Governing Sustainably}

Thus far, I have theorised how sustainability has entered into practices and narratives that environmentalise everyday life and position individuals as 'sustainable' subjects. In this chapter, I focus on the MfE's sustainability narrative and discuss how it functions within the practices of state governance. I approach this by discussing stateand society-centred theories of the state. I then analyse the MfE's narrative as governmentality by focusing on how their narrative individualises sustainability. I argue that the MfE's narrative does this by framing sustainability as a technical problem. In the final two sections I explore how the MfE's sustainability narrative governmentalises sustainability. I concentrate on how the materialisation of the MfE's sustainability narrative governs through disciplinary routines. Finally, I focus on how their sustainability narrative is, potentially, reproduced by being operative in people's experiences as subjects (Zizek, 1994, p. 63).

\section{Theories of the State}

Understanding how sustainability functions within the practices of state governance depends on how the idea of the state is understood. Although it is beyond the scope of this research to provide an in depth analysis of the various state theories, there are two influential approaches to the state (state-centred and society-centred approaches) that provide contrasting ways of understanding and analysing how sustainability functions within the practices of state governance (Goldfinch, 2003, p. 548). Statecentred approaches would focus on the relationships between the autonomous nature of the state and sustainability. One influential approach, which was developed by Theda Skocpol (1985) and others, is state autonomy theory (Goldfinch, 2003, p. 550). This 
state-centred approach focuses on the growing dominance and role of the state in contemporary societies, and its tendency to centralise, control, and rule autonomously (Rose, 1999, p. 15). According to Peter Evans, Dietrich Rueschemeyer, and Skocpol (1985, p. viii) the state is potentially autonomous from civil society, but "socioeconomic relations influence and limit state structures and activities". Rather than simply reflecting the interests and demands of social groups, classes, or society, Skocpol (1985, p. 9) argues that the state is an actor that has its own interests and official goals, which it can implement (depending on its "capacities") "over the actual or potential opposition of powerful social groups or in the face of recalcitrant socioeconomic circumstances". Moreover, the state and its officials act according to a "bureaucratic rationality" that is different and autonomous from "the rationality of social actors" (Bratsis, 2002, p. 251). For example, from this state-centred approach, sustainability has entered into the practices of state governance as part of the growing role that the state plays in controlling and managing natural resources and environmental issues to help develop in ways that meet "the needs of the present without compromising the ability of future generations to meet their own needs" (WCED, 1987, p. 43). From Skocpol's (1985, pp. 14-19) perspective, a state that has 'strong' "tendencies toward autonomous state action" can pursue the goal of sustainability even if it clashes with existing business practices and ideas because it has the capacity to implement sustainability policies and change existing behaviours and “recalcitrant structures". This can be seen in the MfE's (1997, p. 39) statement that "New Zealand businesses are required by law to be environmentally sustainable as set out in rules, plans and consents issued by local authorities or national legislation administered by central government". 
In contrast to state-centred theories, society-centred theories would explore how sustainability functions within the practices of state governance by focusing on the role sustainability plays in maintaining and stabilising capitalist economies and societies while mediating the demands and struggles from within civil society (Barrow, 1993, p. 51). Society-centred theories focus on how the state reflects the various social and class struggles and clashes within society (Goldfinch, 2003, p. 548). An influential societycentred approach is the structural Marxist approach to the state, such as Nicos Poulantzas' and Ernest Mandel's theories of the state (Barrow, 1993, p. 51). In structuralist theories, the state is 'semi autonomous' from civil society and the economy, and, according to Clyde Barrow (1993, p. 8), is "an arena of class struggle" that mediates social and economic conflicts. For example, from a structuralist perspective, the emergence of sustainability within the practices of state governance helps capitalism adapt to the "emerging ecological regime of accumulation" while meeting the demands of social and environmental groups (Barrow, 1993, p. 8; Paterson, 2008, p. 123).

\section{Governmentality, Individualisation, and the State}

In contrast to state- and society-centred approaches, I argue that sustainability functions within the practices of state governance, not as a practice that either demonstrates how the state is autonomous from society or regulates conflicts between the economy and civil society, but as a form of governmentality or technique of government that "[passes] the command structure into the very constitution of the individual" (Douglas as cited in Paterson, 2008, p. 122). To demonstrate this, I focus on how the MfE's sustainability narrative simultaneously frames sustainability as an apolitical, technical problem and as a problem of self-government. 
Defining sustainability. Although some sustainability narratives individualise sustainability, they need an accompanying narrative that supports this idea. I argue that defining sustainability as a technical problem helps legitimise the idea that sustainability is an individual problem. The MfE's definition of sustainability is based on the 1987 Brundtland Commission's definition of sustainable development. Like the Oslo Symposium's definition of sustainable consumption, the 1987 Brundtland Commission defined sustainable development as "development that meets the needs of the present without compromising the ability of future generations to meet their own needs" (WCED, 1987, p. 43). Based on an interpretation of the Brundtland Commission's definition of sustainability, the MfE (2010k) claims that "sustainability is about meeting the needs of today, without adversely impacting on the needs of tomorrow". The MfE (2007a) argue that “this approach [the Brundtland Commission's outline of sustainable development] requires looking after people, taking the long-term view, taking account of the social, economic, environmental and cultural effects of our decisions, and encouraging participation and partnerships".

Another important feature of the MfE's definition of sustainability is the mixing of environmental, social, and economic sustainability (MfE, 2007a). The interconnection of environmental, social, and economic sustainability means that environmental sustainability, for example, is important not "for its own sake", that is, to stop or minimise ecological degradation, but is important for sustainably managing and using natural resources (Marcuse, 1972, p. 62). The same criteria apply to social and economic sustainability: they are important goals, not only for their own sake, but to help achieve environmental sustainability. The MfE (2007a) state that their six sustainability initiatives 
centre on environmental sustainability, but have "strong connections with economic and social sustainability". For example, the MfE's (2007a) Household Sustainability and EcoVerification programmes support 'sustainable' living practices and "economic transformation" while “improving New Zealand's environmental performance”.

Sustainability as an apolitical, technical problem. Fusing environmental sustainability with economic and social sustainability is a dominant theme that runs through sustainability narratives. However, I argue that by fusing the three dimensions of sustainability, the MfE's sustainability narrative transforms environmental sustainability into a technical problem of efficiency by framing it exclusively in terms of monitoring, managing, and using fewer natural resources for the functioning of the economy and society. Indeed, the MfE (2009i) treat sustainability as a problem of "resource efficiency".

However, sustainability is more than an administrative and quantitative issue of managing and using fewer resources (Luke, 1997a, p. 84). Sustainability is also a qualitative or political and social issue that sheds light on taken for granted concepts and ideas. For example, the idea of "needs" raises questions about the distinctions between needs and desires (Luke, 2006b, p. 99). Also, the concept of sustainability, as Luke (1995/2006a, p. 267) argues, “more or less presumes that some level of material and cultural existence has been attained that is indeed worth sustaining”. Furthermore, according to Luke (1997a, p. 84), administrative understandings of sustainability raise the political questions of who is authorised to act as authorities on sustainability and how will sustainability be achieved? 
The MfE's definition of sustainability transforms environmental sustainability into a technical problem of efficiency by framing it as an issue of using "fewer natural resources", producing less waste, and reducing society's 'carbon footprint' (Luke, 1996, p. 19; MfE, 2009i, 2010g). The MfE (2010g) claims that fewer natural resources will be used, less waste will be produced, and people's carbon footprints will be reduced when people and businesses start recycling and adopting more efficient and 'sustainable' living and business practices, and when businesses start reusing material to make products. This can be seen with their Simply Sustainable business model, which describes an "evolution in the business cycle” (MfE, 2010g). Unlike 'traditional' business cycles, where manufacturers, businesses, and customers generate waste that is "put into the environment", the consumer sends recyclables back to the suppliers so that it can be reused in the manufacturing process, which means that the supplier takes fewer natural resources (MfE, 2010g).

Individualisation. Constructing sustainability as a technical problem can be interpreted as an individualisation technique that helps the state govern effectively by objectifying and categorising individuals as environmental or 'sustainable' subjects who, potentially, develop an environmental "consciousness or self-knowledge" while also being subject to the New Zealand government's conception of sustainability (Foucault, 1982, p. 777, 781). While the individualisation of sustainability can be seen as the withering of the state's capacities to rule autonomously (Skocpol, 1985, p. 9), when analysed through Foucault's (1991b) concept of governmentality, individualisation is a crucial dimension of the state's power and its ability to govern effectively. As Foucault (1982, p. 782) argues, “the state's power (and that's one of the reasons for its strength) is 
both an individualizing and a totalizing form of power" that governs effectively by managing individuals and groups of people by combining "individualization techniques" and "totalization procedures". For example, the MfE appear to manage the population at the individual and household levels by encouraging people to live 'sustainably'. The MfE (2010d) claim that living 'sustainably' is important because "small, yet significant actions ... can save money and improve health, while fighting climate change and protecting local environments".

By framing sustainability as an apolitical, technical issue of using fewer resources, the MfE's sustainability narrative depoliticises sustainable consumption and categorises people as 'sustainable' subjects through the idea that sustainability can be solved through the everyday actions of individuals. Although the MfE (2009i) does not have a programme or initiative that is named, Sustainable Consumption, the idea of consuming sustainably underpins their household sustainability and sustainable business initiatives. In their household sustainability initiative, the MfE (2010d) depoliticise sustainable consumption and categorise people as 'sustainable' subjects by framing sustainability in terms of everyday actions that can easily be achieved, which they call "living sustainably". Living 'sustainably', according to the MfE (2010d) is about "smart actions - such as switching off the lights when leaving a room, walking to work, or installing insulation”. More generally, the MfE's (2010d) household sustainability initiative "focuses on the five themes of energy, water, waste, transport, and building".

The idea of "smart actions" is also at the forefront of the MfE's (2010g) sustainable business initiative. Although the MfE's (2010g) sustainable business initiative appears to confront the larger dimensions of sustainability by encouraging businesses to 
adopt "cleaner production" strategies, the theme of everyday actions remain at the forefront of their sustainability narrative. The MfE treat businesses primarily as, what Luke (1997a, p. 122) calls, superconsumers "that can, like other individual consumers or private households, also contribute to ecological change by doing the same 'simple things"”. In their Simply Sustainable business model, the MfE (2010a, 2010e, 2010f, 2010h) encourage businesses to incorporate sustainability into all aspects of business, such as "cleaner production processes", flexible work policies, "socially-responsible investment”, and sustainability and environmental reporting. However, the MfE (2010c) realise that most businesses probably cannot incorporate the ideas of sustainability into every aspect of their business, which is why they claim that there are " 5 easy steps", such as recycling or conserving power, that can help businesses become 'sustainable'. For example, the MfE (2010g) use Palliser Estate Wines as a case study for how a business can become 'sustainable'. While Palliser Estate Wines have made their production processes 'cleaner' or 'sustainable', for example by using a "special waste water system", the MfE (2010g) go into more detail discussing the smaller, everyday practices that Palliser Estate Wines are carrying out, such as recycling office paper, composting food scraps from the staff room, recycling, and stamping their wine boxes with a message that reads: "please recycle".

Although the MfE's idea that everyday actions will help achieve sustainability is 'true' in the sense that it might reduce an individual's 'ecological footprint', it is 'false' or problematic in the sense that it will achieve sustainability, help stop climate change or protect the environment. This does not mean, however, that the MfE's sustainability narrative simply conceals power relations or the political dimensions of sustainability: it 
draws on a technical understanding of sustainability, which provides the rules for how sustainability can be defined and achieved (Foucault, 2000b, pp. 296-297). The MfE's (2010j) conception of sustainability is problematic because it attempts to achieve sustainability in the current 'unsustainable' conditions of production and consumption that are, arguably, largely responsible for environmental degradation and climate change (Luke, 2006b, p. 100). In other words, the MfE's conception of sustainability does not question what Luke (1997a, p. xviii) calls the irrationalities that underlie contemporary issues of resource depletion and unsustainability. Focusing on making people's everyday actions efficient diverts attention away from larger issues, such as the distinction between needs and desires and the current levels of consumption in society, and helps individualise environmental responsibility (Luke, 2006b, p. 99; Maniates, 2001, p. 33). For example, while the MfE (2008a, p. 3) encourage forms of consumption that might help reduce waste, it does not address the paradox of relying on consumption to achieve sustainability (Zizek, 2008b, p. 6).

Sustainability and hegemony. While the MfE's sustainability narrative is problematic, it is still able to appear as a 'natural' or unalterable way of understanding sustainability by hegemonising individualised understandings of sustainability. Alternative understandings of sustainability, such as institutional or structural understandings of sustainability, are almost entirely absent within the MfE's sustainability narrative because the universal idea of sustainability is stitched to the particular ideas of efficiency and small, everyday actions (Zizek, 2008b, pp. 205-207). As Luke (1997a, p. 127) argues, individualising sustainability and ecological problems helps block alternative understandings of sustainability by shifting "most of the responsibility 
and much of the blame away from the institutional centres of power". Whether it was intended or not, the ideas of efficiency and everyday actions function as 'typical' examples of how sustainability can be achieved (Zizek, 2008b, p. 204). These two 'typical' ideas of efficiency and everyday actions are points that hold individualised understandings of sustainability together (Zizek, 2008b, p. 206).

The ideas of efficiency and "smart actions" as 'typical' examples of sustainability can be analysed as an extension of the neo-liberal idea that environmental problems can be resolved through the individual decisions that people make in the marketplace. By adopting efficient, 'sustainable' business practices, individual consumers will want to consume from 'sustainable' businesses. Conversely, by living and consuming 'sustainably' according to the MfE's idea of "smart actions" individual consumers will create a need for 'sustainable' goods and services. I suggest that this approach to sustainability is underpinned by neo-liberal ideas because it is framed in terms of limited government intervention and the 'free' operation of the market place (Maniates, 2001, p. 40). This neo-liberal approach can be seen in the MfE's (2010i) statement that:

Sustainability is not environmentalism in disguise and does not mean suppressing business innovation, or reining in economic growth. It is not business as usual either. The focus of the Ministry's work for business is on encouraging and rewarding businesses with sustainable practices, rather than punishing businesses that don't comply.

However, the MfE's (2010i) approach to sustainability is not only underpinned by free market ideals and limited government intervention. According to M. Dean (2010, p. 175), an important dimension of neo-liberal government is that it "endeavours not only to 
work through the various forms of freedom and agency of individuals and collectives but also to deploy indirect means for the surveillance and regulation of that agency". For instance, rather than directly regulating businesses and the market place, the MfE (2010i) attempt to foster business freedom and economic growth by encouraging businesses to become 'sustainable', which also indirectly governs a business's freedom and agency. According to the MfE (2010b), businesses will be rewarded for adopting 'sustainable' business practices by improving their efficiency and performance, and being able to tap into the emerging "LOHAS" (Lifestyle of Health and Sustainability) or "Cultural Creatives" consumer market, which focuses on issues such as "human rights, fair trade, the environment, sustainable development and personal development". However, by adopting 'sustainable' practices and providing goods and services to environmentally conscious consumers, a business's freedom and agency are indirectly regulated and monitored.

The MfE's neo-liberal understanding of sustainability also appears to conceal the antagonism between achieving sustainability in the prevailing conditions of consumption and production with the fantasy of the 'free market' (Luke, 2006b, pp. 99-100). As Zizek (1997, p. 6, 2008a, p. 142) argues, "ideology has to rely on some phantasmic background" to help avoid "a full rendering of the antagonisms which traverse our society" and to also ". . . take its failure into account in advance". The 'free market' provides the phantasmic backdrop for the MfE's (2010c) claim that sustainability is an issue of making 'smart' or 'efficient' choices by constructing a vision of sustainability that can be achieved through individual 'free choice' rather than structural change. If sustainability is not achieved it is because of the problems in the market or individual 
inadequacies rather than the impossibility of achieving a 'sustainable' society that perfectly balances the demands from ecology, the capitalist economy, and society (Zizek, 2008a, p. 142). For example, drawing on the neo-liberal idea that people are responsible for their choices and so will want to make 'smart' or 'efficient' choices, the MfE (2009a, 2010c) claim that people and businesses should become 'sustainable' because it will help them not only reduce their environmental impact, but will also help them save money. The antagonism between environmental sustainability and economic sustainability is resolved by intertwining the two, and if sustainability is not achieved its failure can be accounted for in terms of people and businesses not making 'smart' and 'efficient' choices.

\section{Discipline and Government}

With their conception of sustainability framed as a largely apolitical, individualised phenomenon, the MfE governs 'sustainably' by encouraging people and businesses to change their 'unsustainable' lifestyles and practices through a range of disciplinary routines. Like individualisation, discipline helps the state govern through normalisation and its "continuous regulatory and corrective mechanisms" that "take charge of life" (Foucault, 1978/2008b, p. 144). When situated within Foucault's (1978/2008b, p. 139) concept of bio-power, disciplinary routines can be analysed as forms of self-management that help regulate the population 'sustainably' at the microlevel. The MfE's individualised sustainability narrative encourages people to reshape their lives and practices through normalising disciplinary practices, which help regulate the population according to their vision of a 'sustainable' society and economy. 
However, the MfE (2008c) also recognise that sustainability is more than a broad environmental, social, and economic practice, which is based solely on the ideas of efficiency and "smart actions", when they claim that sustainability is a core, social value that should underpin people's everyday lives. This can be seen in the following statements: "the Household Sustainability Programme is designed to accelerate a broader adoption of sustainability as a core value that is at the heart of our national identity and part of everyday life in New Zealand", and "sustainability is a social value, an approach to living that underpins a variety of behaviours and choices that New Zealanders make every day" (MfE, 2008b, 2008c).

The MfE do not, however, simply encourage people to incorporate sustainability into their lives; they outline specific, individualised 'sustainable' procedures, practices, and rituals for people to follow that are aligned with their conception of sustainability. The MfE (2008b) argue that "sustainability will not be adopted into New Zealand life if people think that inaction is the norm, or if the problem is too big and difficult for them to act". By doing this, the MfE encourage people to know sustainability as an individualised social value, rather than a social value that encourages institutional thinking and collective action to change existing 'unsustainable' policies and social institutions (Maniates, 2001, p. 34). For example, the MfE's (2009a) household sustainability website encourages people and businesses to live and consume 'sustainably' according to their everyday practices and rituals. In their Household Sustainability Programme, the MfE (2008a) encourage 'sustainable' practices that are based on 25 small, everyday steps, which cut across their seven broad categories: rubbish, water, energy, building, transport, gardening, and shopping. Similarly, the MfE (2010c) outlines five everyday steps that can 
be incorporated into business practices. Businesses are encouraged by the MfE (2010c) to reduce energy waste, recycle, purchase energy efficient office equipment, and consume 'green' office products.

While the MfE encourage people to live 'sustainably', their individualised understandings of sustainability normalise it as a simple, everyday routine. As Luke (1997a, p. 127) suggests, simple, everyday actions appeal to people because sustainability can be incorporated into their everyday routines without any radical change. By encouraging people to change their 'unsustainable' practices, the MfE's narrative normalises everyday understandings of sustainability. Discipline, as Foucault (1977/1991a, p. 180) argues, normalises and corrects through repetitive training. This can be seen in the MfE's (2008b) claim that "practical, do-able actions, such as walking to work or school . . . will support and encourage sustainability as a value in everyday life". At the individual or household level, the MfE's seven broad categories, apart from their "building" category, prescribe a number of repetitive, everyday routines that people can do to become 'sustainable'. First, within the MfE's (2008a, p. 2, 2009f) "rubbish" category, they claim that people can be sustainable by reducing their rubbish; reusing, giving away, or selling their unwanted items; recycling; composting or using a worm farm; and "buying pre-loved, or recycled products". Second, within the MfE's (2008a, p. 4) "water" and "gardening" categories, everyday actions that can help people become 'sustainable', include: "[using] dishwashers and washing machines on full loads", using water wisely, gardening and composting, "[saving] water in the garden", and "[choosing] water efficient products". Third, within the MfE's (2008a, p. 6) “energy" category, everyday 'sustainable' actions include: turning appliances off when they are not in use or 
when people are not in the room; "[using] hot water wisely"; monitoring power use with a power meter; "[choosing] energy efficient products", such as "eco-bulbs"; and taking measures to retain heat within the home, such as closing curtains and purchasing draught stoppers. Fourth, within the MfE’s (2008a, p. 10) "transport" category, everyday 'sustainable' actions include: taking measures to save fuel, such as keeping car tyres inflated to their correct level; walking or cycling instead of driving; car pooling; taking public transport; and choosing a fuel efficient vehicle. Finally, within the MfE's (2009b) "shopping” category, everyday 'sustainable' actions include, but are not limited to: purchasing quality products “. . that will last”; purchasing "pre-loved” or recycled products; and choosing "energy efficient appliances", locally grown food, and "products that display the Environmental Choice tick". At the business level, the MfE also normalise sustainability as an everyday routine. The MfE's (2010c) "five easy steps", outlined above, prescribe a number of routines that employers and employees can engage in to achieve 'sustainable' work practices.

The MfE also normalise sustainability as an everyday routine by differentiating people or businesses according to how 'sustainable' or 'unsustainable' they are. The MfE's (2008a, 2010c) 25 Easy Steps Towards Sustainability booklet, and their five easy steps that businesses can take towards sustainability, disciplines people through a simple ranking system that not only allows people and businesses to ascertain how 'sustainable' they are, but also rewards and punishes by ranking them in terms of how 'sustainable' they are (Foucault, 1977/1991a, p. 181). By carrying out the MfE's prescribed everyday routines and practices, people and businesses can claim that they meet the MfE's minimum requirements for achieving sustainability, which normalises sustainability as an 
everyday, apolitical phenomenon by grading people in terms of how they "measure up to the rule" (Foucault, 1977/1991a, p. 178). For example, each step or procedure that people and businesses carry out helps them achieve sustainability (MfE, 2008a). This can be seen in the MfE's (2008a, p. 1) claim that "the more of us who step up, the bigger difference we'll all make". If people carry out the MfE's (2008a) '25 easy steps towards sustainability" then they can claim that they are 'sustainable'. Or if they cannot carry out all of the 25 steps, they can create a "Next Step" personalised plan, which helps people "select the steps that work for you" (MfE, 2009e). Likewise, if businesses carry out the MfE's (2010c) "five easy steps", then they can claim that they are 'sustainable'.

\section{Self-Governing Sustainable Subjects}

If people are cynical about the idea that everyday actions will achieve sustainability, it is possible that disciplinary routines alone will not reproduce the MfE's govermentalised understanding of sustainability because they will not recognise, or turn themselves into, 'sustainable' subjects (Foucault, 1982, p. 778). For sustainability to be reproduced, it needs to be operative in people's experiences as subjects (Zizek, 1994, p. 63). As Hardt and Antonio Negri (2000, p. 24) claim, "power can achieve an effective command over the entire life of the population only when it becomes an integral, vital function that every individual embraces and reactivates of his or her own accord”.

In this section I explore the underlying fantasies within the MfE's sustainability narrative and how these fantasies (risk-free consumption and production) create imaginary identities (the 'free' consumer and business) that govern people without their belief in the idea that everyday 'sustainable' actions will achieve environmental sustainability (Zizek, 2008a, p. 45). I argue that the MfE's sustainability narrative frames 
everyday 'sustainable' actions not only as an environmental practice, but also as a practice of self-formation and transformation that sustains the imaginary identities of the 'free' business and consumer who can produce and consume without constraint through the fantasy of risk-free consumption and production (Foucault, 2000b, p. 282). The fantasy of risk-free consumption and production sustains the imaginary identities of the 'free' business and consumer by telling them that their lack of enjoyment (not being 'free' to consume and make profits) occurs from excess ('unsustainabiliy') (J. Dean, 2008, p. 57).

Yet, if people are cynical about the idea that everyday actions can achieve sustainability, then quotidian sustainability narratives, and the underlying fantasies that support them, might be ignored. Although it is impossible to know how many people are cynical about the idea of sustainability as an individual problem, Kersty Hobson (2002) explores people's attitudes towards individualised conceptions of sustainability. Hobson (2002, pp. 96-97) explores why individualised sustainability narratives or "the "rationalisation of lifestyle practices"” do not resonate with the people she interviewed. Hobson (2002, p. 95) argues that this is because rationalising lifestyles is removed from larger social justice issues that have greater cultural and social meaning. However, the MfE (2008b) draws on a market research survey that seems to go against Hobson's (2002, p. 96) idea that people are not interested in 'rationalising' their lifestyle practices. According to the MfE (2008b), their research suggests that "78 per cent of respondents in one recent survey believed that they needed to make lifestyle choices to reduce global warming, and 58 per cent of respondents in another survey had thought about or had taken action to reduce the effects of climate change". 
Regardless of whether people do or do not explicitly believe in individualised sustainability narratives, the MfE seem to implicitly recognise that ideology grasps people through enjoyment and fantasy (Zizek, 2008a, p. 48; J. Dean, 2006, p. 8). The ideology of sustainability is underpinned not only by 'rational' or seemingly extraideological concerns, such as climate change or environmental degradation, but also by ideological fantasies, such as business success and consumerism. Although the MfE's (2008b) idea that sustainability is a core social value "that is at the heart of our national identity and part of everyday life in New Zealand" can be seen as the rationalisation of lifestyles, I argue that this social value is also underpinned by the fantasy of risk-free consumption and production (Hobson, 2002, p. 96).

The idea of risk-free consumption and production can be seen in the MfE's Simply Sustainable business model and their household sustainability initiative. Within their Simply Sustainable business model, the MfE promote the fantasy of risk-free consumption and production by telling businesses that 'unsustainability' limits business ‘freedom’ or, more precisely, business efficiency and growth (J. Dean, 2008, p. 57). In terms of business efficiency, rather than being a coercive practice, sustainability is framed as a business ideal that can transform and improve how businesses operate. The MfE (2010k) claim that sustainability will improve business efficiency by allowing businesses to minimise their waste while maximising their resources. When seen through the lens of ideological fantasy and enjoyment, 'unsustainability' is a form of excess that limits a business's enjoyment or ability to make profits (J. Dean, 2008, p. 57). The fantasy of risk-free consumption and production sustains the idea that sustainability is a business ideal by constructing a scene where 'unsustainability' or excess deprives 
businesses from enjoying efficient business practices and business growth (J. Dean, 2008, pp. 56-57; Zizek, 1997, p. 32). This can be seen in the MfE's (2010k) claim that businesses who adopt 'sustainable' business practices report that they have reduced their operating costs, "improved identification and management of risks", "created value through enhance $[\mathrm{sic}]$ and positive customer response", "increased [their] ability to attract and retain employees", and "increased [their] learning and innovation". The MfE (2010g, 2010k) also state that businesses will have "reduced government intervention" if they adopt 'sustainable' business practices.

The MfE also promote the fantasy of risk-free consumption and production to businesses through the idea of sustainable business growth. Sustainability potentially boosts business growth by removing the perception of risk from consumption and consumerism ${ }^{14}$, which encourages people to consume more or the same amount of goods and services and also potentially creates, what Luke (1999a, p. 74) calls, "consumption communities". For instance, the MfE (2010b) claim that because sustainability and environmental concerns are becoming important issues within people's lives, there is a growing need for products and services that are either manufactured 'sustainably' or made by 'sustainable' businesses. According to the MfE (2010b), the LOHAS market "[represents] $32.3 \%$ of the adult US population" and in a similar New Zealand survey they represent $26 \%$ of the adult population. The MfE (2010b) claim that for businesses to

\footnotetext{
${ }^{14}$ According to Smart (2010, p. 5), consumerism "is a way of life that is perpetually preoccupied with the pursuit, possession, rapid displacement, and replacement of a seemingly inexhaustible supply of things"; "it is a way of living that revolves around the wanting of things, the longing for things, the purchasing of things, a way of life in which having, desiring, and wishing for more and more things have become significant preoccupations for late modern subjects whose identities are increasingly bound up with what and how they consume".
} 
be able to tap into the emerging LOHAS market, businesses will have to adopt 'sustainable' business practices.

At the individual and household level, the MfE promote the fantasy of risk-free consumption through the imaginary ideal of consumerism or the idea that people can 'freely' consume. Consumerism can be seen as an imaginary ideal because it plays a large role in how people construct, communicate, and explore their identities (Smart, 2010, p. 5; Ritzer, Goodman, \& Wiedenhoft, 2003, p. 418). The MfE (2009g) discuss a number of ideas to help people consume 'sustainably', which cover the broad areas of shopping, food, waste, and travel. Although the areas of food and travel are important, I limit my analysis to the areas of shopping and waste. I focus here on the MfE's (2009g) idea of "smart shopping" to explore the idea of risk-free consumption and consumerism. The MfE (2009d, 2009h) discuss a number of ideas that go against the idea of consumerism, such as consuming fewer products, buying second hand goods, repairing or re-using household items, and borrowing. However, they also discuss the ideas and practices of "ecolabelling", recycling, and consuming products that are made from recycled materials, which, arguably, are underpinned by the imaginary ideal that people should be able to 'freely' consume.

When used in the MfE's sustainability narrative, "ecolabels", recycling, and producing products that are made from recycled materials supports the imaginary ideal of consumerism by suggesting to consumers that consumption and consumerism can be made environmentally benign or risk-free. In other words, consumerism is tolerated in 'sustainable', risk societies because ecolabelling and recycling remove the environmentally damaging or excessive dimensions from it (Zizek, 2006, p. 238). The 
idea that consumption can be made environmentally benign can be seen in the MfE's (2009d) idea that recycling, and "choosing recycled products or products with recycled content supports recycling initiatives and sends a message to producers to keep supplying these types of products". Risk-free consumption can also be seen in the MfE's (2009c) claim that "independently audited and awarded "ecolabels" have been created to help consumers make choices that will genuinely benefit the environment".

Although the idea of environmentally risk-free consumerism sounds like a contradiction, ecolabelling and producing products that are made from recyclable materials seem to implicitly support the consumerist idea of replacement and ways of living that are based on wanting, longing, and purchasing new or upgraded things (Smart, 2010, p. 5). When analysed through the lens of Beck's (1992, p. 19) conception of the risk society, the idea of protecting the environment through consumerism has the effect of limiting and distributing risks "so that they neither hamper the modernization process nor exceed the limits of that which is [ecologically] 'tolerable"'. Ecolabelling supports consumerism through a form of planned obsolescence ${ }^{15}$ that is justified through the ideas of efficiency and sustainability (Smart, 2010, p. 85). Rather than planned obsolescence being 'bad' for the environment, for example, by using resources unnecessarily and contributing to the amount of physical waste, planned obsolescence and consuming new 'eco' products is 'good' for the environment because they will replace the 'less efficient' 'unsustainable' products. Also, the idea of recycling supports consumerist practices through the idea that consumerism is tolerable so long as people recycle their products or

\footnotetext{
${ }^{15}$ By "planned obsolescence", I do not refer to the idea that products are deliberately designed to have a limited lifespan (Smart, 2010, p. 85). Rather, I refer to Smart's (2010, p. 85) idea that "the development of new products bearing new functions and/or containing technical innovations and additional specifications . .. lead existing products to be regarded as obsolete and virtually worthless by virtue of their significantly inferior range of functions and performance".
} 
buy products that are made from recycled materials. In other words, consumerism is tolerated so long as it does not impact on the environment. This can be seen in the MfE's (2009k) idea that, "when you shop, you can do your bit [for the environment] by purchasing products with content and packaging that is able to be recycled ... [and reusing or recycling] these at the end of their lives". The MfE (1997, p. 42) do recognise the contradiction between recycling and being "environmentally-friendly" in their 1997 report, State of New Zealand's Environment, which discusses the idea that recycling "is less environmentally-friendly than waste reduction and product reuse" and potentially allows "continued industrial throughput and a convenient environmental excuse for planned obsolescence". However, recycling still plays an important role in their sustainability narrative.

To summarise, I have argued that sustainability functions within the practices and narratives of state governance as a form of governmentality that "[passes] the command structure into the very constitution of the individual" (Douglas as cited in Paterson, 2008, p. 122). The MfE's sustainability narrative positions individuals as 'sustainable' subjects by encouraging them to change their 'unsustainable' lifestyles and practices through a range of environmentalised disciplinary practices and practices of the self. The MfE's individualised conception of sustainability appears to be a 'natural' or unalterable way of understanding sustainability because it is stitched to the particular ideas of resource efficiency and 'smart', everyday actions. While people may be cynical about the idea of everyday, 'sustainable' actions, the MfE's everyday practices of living and consuming 'sustainably' are potentially reproduced through the creation of imaginary identities (the 'free' consumer and business) that are operative in people's experiences as subjects 
(Zizek, 1994, p. 63). The MfE's quotidian practices of living and consuming 'sustainably', therefore, are not simply linked to the idea of consuming resources efficiently, but appear to be intimately connected with the management of the population at the individual and household levels. 


\section{Chapter Four: Governing the Market}

I have focused on the MfE's sustainability narrative and how it encourages businesses to adopt environmentally 'sustainable' business practices. I now focus on Genesis Energy's sustainability narrative and how it functions as a market narrative. I argue that Genesis Energy's sustainability narrative is not only an attempt to 'green' their business practices, but also has the effect of environmentalising people's everyday lives. This chapter is divided into four sections. In the first part of the chapter, I analyse how Genesis Energy's sustainability narrative functions as a market narrative by discussing two discourse types employed in their narrative (Fairclough, 1992, p. 124). I then compare Genesis Energy’s corporate sustainability narrative with their quotidian sustainability narrative and discuss how, as an ideological doctrine that individualises and depoliticises sustainability, their sustainability narrative environmentalises people's everyday lives by categorising individuals as 'sustainable' subjects. In the third section, I discuss how Genesis Energy's sustainability narrative establishes 'sustainable' subject positions through disciplinary dividing practices (Foucault, 1982, p. 777). Finally, I examine how their narrative encourages people to turn themselves into 'sustainable' subjects.

\section{Sustainability and the Market}

Analysed as a market narrative, Genesis Energy's sustainability discourse frames environmentally 'sustainable' business practices as a productive force that improves business efficiency and performance (Luke, 2006b, p. 102). Here, I discuss two relatively widespread ways of understanding environmentally 'sustainable' business practices that Genesis Energy's narrative implicitly employs. By identifying what discourse types 
Genesis Energy's narrative draws on, I aim to demonstrate how sustainability narratives operate as market narratives (Fairclough, 1992, p. 124).

Environmentally 'sustainable' business practices can be understood as an environmental effort to help preserve "Nature's biotic diversity in order to maintain the sustainability of the biosphere" at the expense of business performance and profitability (Luke, 1995/2006a, pp. 266-267). Yet, as it is discursively constructed by Genesis Energy, environmentally 'sustainable' business practices do not impede business efficiency or performance, but improve how a business operates and can help businesses tap into new markets (Luke, 1995/2006a, p. 267). Genesis Energy (2010a) contends that environmentally 'sustainable' business practices can help improve a business's efficiency and financial performance. For example, in highlighting to tradespeople how employing environmentally 'sustainable' business practices can benefit their business, Genesis Energy (2010a) claim that these business practices do not have to hinder a business's performance or their ability to make profits:

We're all trying to live and work more sustainably. But that doesn't have to mean running around in hemp overalls, living in mud huts and running your power tools off a windmill. In fact, these days it's not only practical to be more sustainable, it can also be profitable.

Sustainability discourses that focus on how environmentally 'sustainable' business practices can benefit businesses can be analysed as, what Luke (1997a, p. 128, 2006b, p. 102) calls, "ecocommercialism" and "green consumerism" discourses, which attempt to integrate economic and environmental interests to maximise business competitiveness, profits, and efficiency while helping to protect the natural environment. 
As Luke (2006b, p. 102) explains, the idea that being environmentally 'sustainable' can benefit businesses emerges "when and where natural resource management policies, global competition, activism, and international bench-marking shift the currents of corporate thinking into more positive channels".

As an ecocommercialist discourse, environmentally 'sustainable' practices, as argued by Paul Hawken, Amory Lovins, and Hunter Lovins (1999, pp. xi-xiii), can help businesses sustain their competitive advantage by integrating economic, environmental, and social concerns into every dimension of business. Hawken et al. (1999, p. xii) claim that integrating and achieving these three concerns can help businesses become 'ecoefficient' by improving resource productivity and changing how resources are used. For example, power companies, such as Genesis Energy (2009, p. 32), can expand their "natural capital" (capital that is not produced by human activity) by generating power from renewable sources, such as water, wind, and sunlight, which ensures that their business "is viable for the long term, delivers value for our shareholders, and contributes lasting benefits to society" (Hawken et al., 1999, p. 151).

As a 'green' consumerism discourse, generating power 'sustainably' from renewable sources is said to benefit businesses because it can help power companies tap into 'green' consumer or LOHAS markets. Although 'green' consumerism is a broad term that can refer to people consuming less products and services or consuming efficiently, it can also refer to the development of "fresh psychodemographic niches of need" that are based on the consumption of products and services that are 'green' or environmentally friendly (for example, products that are made from recycled materials) (Luke, 1997a, pp. 119-128). In order to tap into the emerging 'green' consumer markets, 
businesses, presumably, need to demonstrate how they are environmentally 'sustainable'. Generating power 'sustainably' from renewable sources, for example, is one way to demonstrate to customers that a power company is 'environmentally responsible' and has environmental values. Genesis Energy's (2010g) Generation Diversity television advertisement highlights how businesses attempt to attract customers who are interested in the idea of environmental sustainability by drawing on 'green' consumerism discourses (see appendices $\mathrm{A}$ and $\mathrm{C}$ for transcription and transcript notational conventions). The advertisement suggests that people should consume power from Genesis Energy (2010g) because they can 'sustainably' generate power by "[generating] power from more sources than anyone else", which suggests that they are helping establish an environmentally 'sustainable' society. This is implied in the statement "if you're able to pick and choose from many sources, you're less likely to run out ... so your future is more secure" (Genesis Energy, 2010g).

\section{Environmental Sustainability and Corporate Governance}

In addition to functioning within market discourses as an ecocommercialism and 'green' consumerism discourse that improves a business's efficiency and financial performance, market based sustainability narratives, I argue, are simultaneously forms of environmentality or narratives about exercising power over life (Luke, 1995/2006a, p. 267; Foucault, 1978/2008b, p. 139). To demonstrate this, I compare Genesis Energy's corporate sustainability narrative with their quotidian sustainability narrative and discuss how it normalises individualised conceptions of sustainability.

Genesis Energy's (2009, p. 32) corporate governance narrative incorporates "economic and environmental sustainability principles" and is materialised within their 
2009/2010 Business Plan, corporate governance statement, and their strategic direction. According to Genesis Energy (2009, p. 4), "being a sustainable business means being efficient, financially viable, socially responsible and committed to good environmental management". Because Genesis Energy's (2010k) operations impact and rely on the natural environment, their environmental sustainability narrative is framed primarily as a technical issue of managing resources responsibly and reducing carbon emissions. They claim to be managing their environmental resources responsibly by providing energy "production and generation solutions that demonstrate strong sustainable performance" (Genesis Energy, 2009, p. 32). For example, Genesis Energy (2009, p. 28) report that they are developing their renewable energy capability by exploring and investigating a number of potential wind, hydro, and geothermal sites around the North and South Islands of New Zealand.

In terms of carbon emissions reductions, Genesis Energy (2009, p. 32, 2010d, 2010h) assert that they are managing and reducing their carbon emissions while growing their business by not only addressing "the effects of its operation based on resource consent requirements", but by also reducing their operational footprint and being involved in a number of community projects. To reduce their operational footprint, Genesis Energy (2010h, 2009, p. 34) contend that they are minimising their office waste, incorporating sustainability into their purchasing decisions, establishing 'sustainable' building guidelines for refurbishment, consuming office electricity 'sustainably', conducting energy audits across all their sites, and purchasing carbon credits to offset non generation activities. Furthermore, they claim to be reducing their carbon footprint by supporting and being involved in a number of community initiatives, such as the Waikato 
River Enhancement Society, which "plant[s] native vegetation on the banks of the lower Waikato River and maintain[s] the area" (Genesis Energy, 2010c, 2010j).

Genesis Energy's sustainability narrative, however, stretches outside their corporate governance narrative and transforms into a governing narrative that encourages individuals to incorporate sustainability into their everyday lives. Genesis Energy (2010b, 2010i) not only attempt to achieve environmental sustainability by reducing their carbon emissions and responsibly managing their resources, but also encourage their customers to reduce their greenhouse gas emissions and environmental footprint by "saving energy at home". Genesis Energy (2009, pp. 34-35, 2010k) believe that "sustainability is everybody's responsibility" and "young people [need] the opportunity to grow up learning about the importance of what it means to be a responsible steward of the environment". The energy saving tips that Genesis Energy (2010i) suggest to their customers are small, everyday actions, such as replacing incandescent light bulbs with fluorescent lamps, turning off appliances at the wall, turning off lights when they are not in use, fixing dripping taps, and making sure that the hot water temperature is not higher than 55 degrees at the tap, as well as more costly actions, such as installing insulation, heat pumps, and gas hot water systems.

On one level, Genesis Energy's sustainability narrative can be interpreted as a 'green' consumerism narrative that helps them tap into 'green' consumer markets, but at another level, it can be interpreted as a form of environmentality that attempts to regulate the population at the anatamo- and bio-political levels (Luke, 1999b; Foucault, 1978/2008b, p. 139). Foucault (1977/1991a, p. 211) notes how "the Christian School must not simply train docile children; it must also make it possible to supervise the 
parents, to gain information as to their way of life, their resources, their piety, their morals”. Similarly, Genesis Energy's disciplinary routines not only help reduce their operational footprint, but also help manage the population at the micro, individual level by encouraging people to incorporate sustainability into their everyday lives (Foucault, 1977/1991a, p. 212).

In fact, 'green' consumerism, ecocommercialism, and environmentality are intricately connected; practices of 'green' consumerism and ecocommercialism rely on techniques of power that "synchronise the bio-powers of populations with the geo-powers of environments" (Luke, 1997a, 2006b, 1995/2006a, p. 266). Foucault (1978/2008b, pp. 140-141) reminds us how disciplinary power and "bio-power was without question indispensable to the development of capitalism; the latter would not have been possible without the controlled insertion of bodies into the machinery of production and the adjustment of the phenomena of population to economic processes". Likewise, the development of a "society in which political power had assigned itself the task of administering life" would not have occurred and "would not have been possible ... without the growth of an apparatus of production capable of sustaining them and using them" (Foucault, 1978/2008b, p. 139, 1977/1991a, p. 221).

Individualisation and depoliticisation. The connection between the management of the population and the regulation of the environment is manifest in Genesis Energy's sustainability narrative, which simultaneously individualises and depoliticises sustainability, and categorises and positions individuals as 'sustainable' subjects. While Genesis Energy’s (2010f) sustainability narrative includes a number of large-scale initiatives for achieving sustainability, their Climate Change television advertisement can 
be seen as a governing narrative that does not focus on these larger understandings of sustainability. Instead it depoliticises the issue of sustainability by framing it primarily as an individual problem that can be solved through small, everyday actions.

Although Genesis Energy's (2010f) advertisement does not explicitly state that people should consume power 'sustainably', the visual images, dialogue, and lyrics suggest that it is a sustainability advertising campaign. The advertisement tells a brief story about an adult Pukeko, who is followed by two baby Pukekos, entering into a house during daylight hours and switching off a lamp. The story suggests that people should either consume power less or more efficiently. The voiceover, "we can all do our bit for climate change if we make it part of our everyday lives", implies that people should consume 'sustainably' because it is good for the environment. Also, shot ${ }^{16} 13$, which focuses on the baby Pukekos while fading to Genesis Energy's logo and the words "hello tomorrow", implies that people should consume efficiently because it will benefit future generations. By focusing on individuals consuming power efficiently and by connecting power usage to climate change, Genesis Energy's (2010f) advertisement encourages people to consume power 'sustainably' because it connects with the definition of sustainable consumption that was developed at the 1994 Oslo Symposium. For example, Genesis Energy's idea that people should consume power efficiently, meshes with the idea that consumption should “. . . respond to basic needs and bring a better quality of life, while minimizing the use of natural resources" (1994 Oslo Symposium as cited in Paterson, 2008, p. 111). Also, Genesis Energy's (2010f) reference to climate change and

\footnotetext{
${ }^{16}$ According to Rick Iedema (2001, p. 189), a shot is an unedited camera movement; "if the camera's position changes this may be due to panning, tracking, zooming, and so on, but not editing cuts". Whereas, "in a scene the camera remains in one time-space, but is at the same time made up of more than one shot (otherwise if would be a shot)" (Iedema, 2001, p. 189).
} 
future generations ties in with the idea that consumption should minimize ". . the emissions of waste and pollutants ... so as not to jeopardize the needs of future generations" (1994 Oslo Symposium as cited in Paterson, 2008, p. 111). In fact, Genesis Energy (2009, p. 32) explicitly acknowledge the connection between climate change and sustainability in their statement that "addressing climate change is still an integral part of our approach to sustainability".

Genesis Energy’s (2010f) advertisement individualises ‘sustainable’ power consumption, which, subsequently, environmentalises people's lives by categorising them as 'sustainable' subjects. First, utilising an adult Pukeko and two baby Pukekos as metaphors to signify an adult human (or a Genesis Energy customer), and human children, individualises 'sustainable' power consumption by portraying a Pukeko switching off a lamp. At the denotative level, the Pukekos are just animals that enter a house and switch off a lamp. The use of Pukekos in the advertisement suggests that saving power is easy. If a Pukeko knows how to save power, then a human being should be able to save power. However, the Pukekos also signify human beings and/or Genesis Energy's customers because they enter a house for the sole purpose of switching off a lamp that was not in use. The Pukeko represents New Zealanders because it is native to New Zealand. The Pukekos, therefore, help reinforce the idea that individuals can help fight climate change and achieve sustainability.

Second, framing sustainability in terms of everyday actions that each individual can achieve shifts the focus from how Genesis Energy produces its power to how individuals should consume power in their homes. Switching off a lamp during daylight hours and when no one is in a room is portrayed as one way of consuming power 
'sustainably' because it will reduce the amount of electricity that a household uses. Although it is not explicitly stated, the message is that individuals should turn off any household appliances if there is no one in the room and/or if a room contains natural light.

Third, the narrative individualises sustainable consumption by stating that consuming power 'sustainably' is everybody's problem (see appendices B and C for transcription and transcript notational conventions). The advertisement's narrator says, "we can all do our bit for climate change if we make it part of our everyday lives. Together we can make a big difference to tomorrow" (Genesis Energy, 2010f). Although the words "we", "all”, "our", and "together" can refer to Genesis Energy and other businesses or governments, it appears as though it is used in this statement to refer to individuals because the narrator frames sustainable consumption as an "everyday" problem. Also, the words "bit" and "it", which seem to refer to the idea of consuming sustainably, signify an individualised conception of sustainability by being weighed against a "definite signified” (the Pukeko switching off a lamp) (Barthes, 1957/2001, p. 113). The words "everyday" and "bit" function ideologically by suggesting that small changes in an individual's everyday life can make a significant difference to climate change, rather than larger changes, such as constructing wind turbines rather than thermal power plants. Furthermore, the words "can", "do", and "make a big difference to tomorrow" portrays sustainable consumption as something that is easily achievable by each individual. This helps reduce complex problems into problems that can be achieved if each individual switches off a light bulb or carries out other small, everyday actions. Because there are no simple solutions to global environmental problems, such as climate 
change, businesses are able to claim that small, everyday actions "make a big difference to tomorrow" (Maniates, 2001, pp. 42-43; Genesis Energy, 2010f).

Finally, the lyrics environmentalise as they place the responsibility for sustainable consumption onto the individual consumer. The lyrics, "you know that there is nothing that I wouldn't do, when it comes to doing stuff for you [the natural environment]", imply that individuals are responsible for conserving electricity. The use of the personal pronoun "I" highlights that conserving electricity is an individual problem not a collective problem. Also, the use of the word "stuff", rather than "conserving electricity" or being "environmentally friendly", helps keep open the range of actions that individuals can do to help the environment. This could refer to simple tasks such as switching off electrical appliances when they are not in use, or to tasks that require more effort, such as walking rather than driving. Or, it could refer to consumers consuming power from a 'green' power company, such as Genesis Energy. The word "stuff" could also refer to larger actions, such as building wind farms, but because it is used informally and because it is situated within the context of a Pukeko turning off a light, it implies that consuming sustainably is an individual problem.

The advertisement not only individualises sustainability, but has the effect of normalising individualised conceptions of sustainability by drawing on the idea that sustainability is a technical problem of using fewer resources that can be achieved through everyday actions. Everyday actions, such as turning off light bulbs, are framed as being "ecologically sensible" because they will help reduce the amount of carbon dioxide released into the atmosphere (Luke, 2009b, p. 29). However, the focus on "ecologically sensible" actions deflects attention away from the fact that Genesis Energy's (2010e) 
thermal or "gas and/or coal" power plant is not an environmentally friendly method of generating power (Luke, 2009b, p. 29; Bodley, 2008, p. 119). Indeed, Luke (2009b, p. 29) argues that although people have been carrying out "ecologically sensible" tasks for decades, "the climate crisis has only worsened". In other words, by focusing on individuals consuming 'sustainably', Genesis Energy deflects attention away from the fact that they are not consuming 'sustainably'.

This advertisement also hegemonises individualised conceptions of sustainability by accounting for its efficiency with reference to the neo-liberal idea of individual responsibility (Zizek, 2008b, pp. 204-205). Genesis Energy (2010b) acknowledge that sustainability is a complex issue that will require the construction of "renewable energy projects", but the statement, "we can all do our bit for climate change if we make it part of our everyday lives. Together we can make a big difference to tomorrow" accounts for its efficiency by claiming that it can be made part of everyday life. Like the MfE, Genesis Energy use small, everyday actions as 'typical' examples of how sustainability can be achieved (Zizek, 2008b, p. 204). The aforementioned statement suggests that people's everyday activities are inefficient and set a bad example for future generations (signified by the baby Pukekos) and so should be made 'sustainable'. This normalises individualised conceptions of sustainability by implying that reshaping each individual's 'unsustainable' daily routines is just as crucial as larger actions, such as generating power from renewable energy sources (Luke, 1995/2006a, p. 266).

\section{Sustainable Power Consumption as a Disciplinary Practice}

Thus far I have discussed how Genesis Energy's sustainability narrative has the effect of environmentalising people's everyday lives by depoliticising and individualising 
sustainability. As well as normalising individualised conceptions of sustainability through ideology and hegemony, Genesis Energy's practices for consuming and living 'sustainably' potentially transform individuals into 'sustainable' subjects through environmentalised disciplinary dividing practices, which are practices or rules for how to live and consume 'sustainably' (Foucault, 1982, p. 777, 2000b, p. 285; Luke, 1999b, p. 143). More specifically, rather than simply dividing people into 'normal' and 'abnormal' categories, Genesis Energy's climate change advertisement normalises individualised conceptions of sustainability by creating an individualised model for how to consume and live, and then encouraging people ". . . to conform to this model"17 (Foucault, 2007, p. 57).

The advertisement's disciplinary practices for consuming and living 'sustainably' potentially create 'sustainable' subjects by dividing individuals into the categories of 'sustainable' and 'unsustainable' or 'normal' and 'abnormal' (Foucault, 1982, p. 777; Luke, 1990, p. 243). As Foucault (1982, pp. 777-778) argues, people are turned into subjects through objectifying dividing practices by being "divided within himself or divided from others". Dividing practices distribute people's actions and behaviours "between a positive pole and a negative pole" or between 'normal' and 'abnormal' (Foucault, 1977/1991a, p. 180). By constructing a model for how to live and consume ‘sustainably', Genesis Energy's climate change advertisement divides people from others through the categories of "sustainability" and "unsustainability". Scenes three and four, where the adult Pukeko leads the younger Pukekos into the house and they watch the adult Pukeko switch off a lamp, divides 'unsustainable' forms of living from 'sustainable'

17 As Foucault (2007, p. 57) argues, "it is not the normal and the abnormal that is fundamental and primary in disciplinary normalization", rather, it is that which can adhere to the norm. 
forms of living by establishing 'normal' procedures for consuming power. In shots 10, 11, 12, and 13 the adult Pukeko identifies that someone has left a light on in an empty room during daylight hours. The adult Pukeko then enters the room and switches off the lamp in front of the younger Pukekos. The adult Pukeko signifies that either Genesis Energy or a parental figure is disciplining their consumers or children (the baby Pukekos) to consume 'sustainably'. The Pukeko demonstrates to the baby Pukekos that they need to switch off any household appliances that are not in use or do not need to be in use. In other words, the adult Pukeko establishes an individualised model for consuming and living 'sustainably' (switching off household appliances when they are not in use), which acts as a norm or an "optimal model", and then demonstrates that individualised forms of 'sustainable' power consumption are 'normal' because they adhere to this norm, whereas 'unsustainable' forms of power consumption (leaving on household appliances when they are not in use) are 'abnormal' because they do not (Foucault, 2007, p. 57).
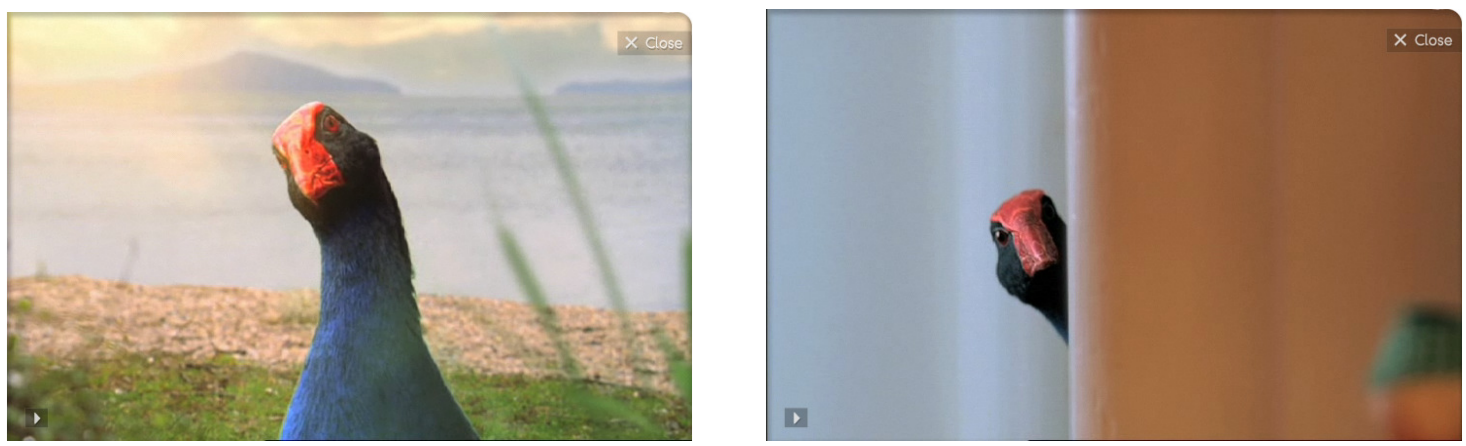

Figure 1. Shots 1 and 9 (Genesis Energy, 2010f).

Genesis Energy's advertisement also divides people's ways of living in terms of 'sustainable' and 'unsustainable' through the categories of 'natural' and 'unnatural'. 
Scene four, where the Pukekos enter into the house and switch off the lamp, helps to establish 'abnormal' and 'normal' ways of living by implying that the people who live in the house are 'unsustainable' power consumers because the Pukeko had to switch off the lamp. Shots 1 and 9 suggest that the Pukeko realised that the people in the house were using power 'unsustainably' and so was compelled to switch off the lamp (see figure 1). In the first scene, the Pukeko has noticed that a lamp has been left on in the house because its head is tilted, which implies that the Pukeko has noticed something abnormal. This is reinforced when the adult Pukeko walks past a room, but then returns to the room because it has noticed that a lamp was left on when it was not in use. Shot 12, where the Pukeko switches off the lamp, implies that individualised forms of sustainability are normal and 'natural' because a non-human animal is able to tell the difference between 'sustainable' and 'unsustainable' power consumption; it knows that leaving a lamp switched on when no one is in the room is 'unsustainable'. Therefore, using electrical appliances when they are not in use is abnormal and 'unnatural', whereas the routine of turning off electrical appliances and being aware of your consumption habits is normal and 'natural'.

As well as dividing individuals into the categories of "sustainability" and "unsustainability", the advertisement also trains people to consume 'sustainably' through rewards and punishments (Foucault, 1982, p. 777, 1977/1991a, pp. 180-181). The advertisement encourages people to consume 'sustainably' by claiming that consuming ‘sustainably' will reward them with a ‘clean and green’ environment. In other words, consuming 'sustainably' rewards people with the promise of a 'clean and green' environment, and consuming 'unsustainably' punishes people by taking this promise 
away (Foucault, 1977/1991a, p. 181). The statement, "we can all do our bit for climate change if we make it part of our everyday lives. Together we can make a big difference to tomorrow", encourages people to carry out the 'normal' or 'correct' method of consuming 'sustainably' by claiming that everyday actions help minimise or stop climate change. The advertisement's lyrics, “you know that there is nothing that I wouldn't do, when it comes to doing stuff for you, ain't no mountain high enough it's true. True, true, true, true, true ..." also tells the audience that everyday, 'sustainable' actions are 'good' for the environment. The words, "doing stuff for you", implies that consuming 'sustainably' (signified by the words “doing stuff”) is 'good' for the environment. The rest of the lyrics, “. . a ain't no mountain high enough it's true. True, true, true, true, true . .." reinforces and extends ${ }^{18}$ the idea that everyday, 'sustainable' actions are 'good' for the environment by suggesting that, although being a 'sustainable' power consumer can be difficult, it is the 'normal' way to live and consume.

\section{Sustainable Power Consumption as a Practice of the Self}

So far I have discussed how Genesis Energy's advertisement has the effect of normalising individualised conceptions of sustainability by objectifying and positioning people as 'sustainable' subjects, but recognising one's self as a 'sustainable' subject is also crucial in the reproduction of individualised conceptions of sustainability. Genesis Energy's advertisement encourages people to turn themselves into 'sustainable' subjects by framing everyday 'sustainable' actions as a practice of the self that removes the excessive dimensions from living and consuming (Foucault, 2000b, p. 291; Zizek, 2004,

\footnotetext{
${ }^{18}$ According to Fairclough (1992, p. 175), a clause is extended when "one clause (sentence) extends the meaning of another by adding something new to it".
} 
p. 507). Living and consuming 'sustainably' is encouraged as one way of removing any dangerous or excessive dimensions from life because it replaces the practices of living and consuming that impact negatively on the environment. In other words, as a form of tolerance without intrusion, Genesis Energy's sustainability narrative encourages people to live and consume how they want so long as its excessive, intrusive dimensions are removed (Zizek, 2004, p. 508). This is demonstrated in the first two scenes of Genesis Energy's (2010f) advertisement, which suggests that a person can still live how they please (they can own a house next to a beach, own a car etc.), but they have to remove its excessive or 'unsustainable' dimensions (leaving a light bulb on during daylight hours, for example).

In order to encourage people to adopt everyday, 'sustainable' actions and to demonstrate that sustainability is not just an "add-on" to their business, Genesis Energy (2009, p. 32) assert that they are also subject to their individualised conception of sustainability by attempting to remove the excessive, 'unsustainable' practices from their business. Genesis Energy (2009, p. 32) does this by reviewing and changing their 'unsustainable' business practices and encouraging every employee "to demonstrate and deliver responsible business practice in whatever they do". For example, by conducting energy audits and undertaking various activities to reduce power consumption, Genesis Energy (2009, p. 34) claim that the total amount of energy consumed in their Auckland and Wellington offices decreased during 2009 and the removal of uncontrolled heaters from several of their power stations saved 61,320 kilowatt hours of energy.

As well as encompassing environmental concerns, the everyday, 'sustainable' actions in Genesis Energy's narrative are also underpinned by the ideological fantasy of 
living and consuming without risk. Although everyday, 'sustainable' actions appear to be underpinned by utilitarian or practical concerns, rather than a fantasy scenario, Zizek (1997, p. 6) reminds us how fantasy scenarios appear "where one would not expect to find it: in marginal and, again, apparently utilitarian situations”. Like the MfE, Genesis Energy (2009, p. 32) recognises "that sustainability is not just about physical programmes and community contributions, but is also about social values, attitudes and behaviours evident in day-to-day operations". As well as being evident in their business practices, sustainability, as a social value, also permeates Genesis Energy’s (2010f) Climate Change advertisement. They seem to recognise that people will not believe that everyday, 'sustainable' actions will achieve sustainability and so frame them as important social values for living and consuming without risk. Genesis Energy's (2010f) advertisement encourages people to recognise themselves as 'sustainable' subjects by framing it as part of the fantasy of being 'free' to live and consume without risk. Genesis Energy's (2010f) advertisement tells people that their lack of enjoyment (not being free from environmental concerns) occurs through 'unsustainability' or excess (Zizek, 2004, p. 508; J. Dean, 2008, p. 57).

Rather than being encouraged to live and consume 'sustainably' to help fight climate change and reduce natural resource use, people are encouraged to live and consume 'sustainably' so that they can enjoy a life that is free from risk. Genesis Energy's (2010f) advertisement, then, is not only a message about stopping environmental degradation or making "a big difference to tomorrow", but is also an injunction to enjoy a life free from risk and environmental intrusion (Zizek, 2004, pp. 508-509). The advertisement implies that if people carry out small, everyday routines, 
such as switching off light bulbs when no one is in the room, then they can continue to enjoy their current lifestyle (living in a house next to the sea and owning a car) without having to sacrifice any significant aspects of it (using public transport rather than driving a car or sacrificing an unpolluted sea for a polluted sea) for the sake of the natural environment because they would have removed the excessive 'unsustainable' dimensions from it. In other words, by constructing a scene where 'unsustainability' or excess deprives people from enjoying, Genesis Energy's advertisement implies that everyday, 'sustainable' actions remove the excessive or 'unsustainable' aspects from a person's lifestyle and consumption habits so that they can enjoy their current lifestyle (J. Dean, 2008, pp. 56-57; Zizek, 1997, p. 32).

Not only does the advertisement encourage people to enjoy a life free from environmental intrusion, it also supports the perception that 'unsustainability' limits their ability to enjoy financial freedom. Although the advertisement does not explicitly make the connection between everyday, 'sustainable' actions and saving money, it implies that sustainability can help people save money because it is efficient and can "make a big difference to tomorrow" (Genesis Energy, 2010f). The statement, "make a big difference to tomorrow", is ambiguous and seems to be a rewording ${ }^{19}$ of "protecting the environment" or "fighting climate change" (Genesis Energy, 2010f). The modifiers "together" and "we", in the clause, "together we can make a big difference to tomorrow", gives it a collective meaning ("our tomorrow"), rather than an individual meaning ("my tomorrow" or "your tomorrow”) (Fairclough, 1992, p. 94; Genesis Energy, 2010f). However, by being framed within the context of the Pukeko switching off the light, the

\footnotetext{
${ }^{19}$ According to Fairclough (1992, p. 194), "rewording" is a term that refers to the generation of "new wordings which are set up as alternatives to, and in opposition to, existing ones".
} 
clause, "together we can make a big difference to tomorrow", suggests that people can help protect the environment and fight climate change while saving money, which gives the word "tomorrow" collective and individual meanings (Genesis Energy, 2010f). Genesis Energy (2010i) explicitly acknowledges the connection between protecting the environment and saving money in their energy efficiency narrative, which claims that "improving your energy efficiency today is a step towards a brighter future tomorrow". In other words, people can "make big savings" on their electricity bill while helping to protect the environment (Genesis Energy, 2010i). Not consuming power efficiently or 'sustainably', then, is portrayed as a form of excess that deprives people from enjoying financial freedom and a clean, 'green' New Zealand (J. Dean, 2008, p. 57).

To summarise, in this chapter I have discussed how sustainability not only functions within market-based sustainability narratives as an ecocommercialism and 'green' consumerism discourse, but also as a form of environmentality. As a corporate governance practice, sustainability plays an important role in directing Genesis Energy's business by helping them become an efficient and viable business. Genesis Energy's focus on encouraging people to incorporate sustainability into their everyday lives, therefore, could be interpreted as a corporate governance practice that helps them tap into 'green' consumer markets. However, I have argued that Genesis Energy's sustainability narrative can also be interpreted as a form of environmentality that helps manage the population at the individual level by normalising individualised understandings of sustainability. Genesis Energy's sustainability narrative individualises sustainability by framing it as a technical problem of using fewer resources that can be achieved through everyday actions. After rendering individuals responsible for sustainability, Genesis 
Energy's sustainability narrative potentially transforms individuals into 'sustainable' subjects through disciplinary dividing practices. Also, by drawing on the moral and phantasmic dimensions of sustainability, Genesis Energy encourage people to turn themselves into 'sustainable' subjects by framing everyday 'sustainable' actions not only as an environmental practice of the self, but also as a practice of living and consuming without risk (Foucault, 2000b, p. 291). 


\section{Chapter Five: Governing Civil Society}

So far I have focused on the sustainability narratives that are generated within the spheres of the state and the market. I now analyse how Greenpeace's sustainability narrative functions as a civil society narrative. In contrast to the MfE and Genesis Energy, Greenpeace appear to be opposed to individualised understandings of environmental protection and sustainability. However, I argue that although it appears as though Greenpeace's sustainability narrative differs radically from state and market narratives, it also environmentalises everyday life and normalises individualised conceptions of environmental sustainability and sustainable consumption. This chapter is divided into four sections. In the first section, I analyse Greenpeace's narrative as a global civil society narrative by exploring two theoretical perspectives that underpin their environmental protection and sustainability narratives. In the final three sections I analyse their narrative as environmentality by contrasting it with the MfE's and Genesis Energy's narratives. In section two, I focus on the political and ideological effects of Greenpeace's narrative and how it objectivises and positions people as subjects and objects of knowledge (Fairclough, 1992, p. 238; Foucault, 1983, p. 237, 1982, p. 777). I discuss how people are categorised as 'sustainable' subjects by analysing the political, apolitical, and ideological dimensions of Greenpeace's sustainability narrative. In the final two sections of this chapter, I discuss how 'sustainable' social identities or subject positions are set up and potentially normalised in Greenpeace's sustainability narrative (Fairclough, 1992, p. 64). I analyse how Greenpeace 'green’ everyday life through “ecodisciplinary” practices and then discuss how they encourage people to turn themselves into 
environmentally 'sustainable' subjects by framing sustainability as a practice of the self (Luke, 1999a, p. 153).

\section{Civil Society and Environmental Protection}

As a global civil society non-governmental organisation (NGO) that claims to protect civil society and the environment from environmentally 'unsustainable' business and government policies and practices, Greenpeace's (2009, p. 3) sustainability narrative can be analysed as an environmental narrative that investigates and exposes "environmental abuse by governments and corporations". In order to analyse the single narrative that appears to cut across the supposed boundaries between the state, market, and civil society, I analyse Greenpeace's narrative as a discursive practice and focus on its interdiscursive dimensions (Fairclough, 1992, p. 85). I briefly discuss Greenpeace’s connection with environmental sustainability and then explore two environmental discourses that their narrative draws on.

Greenpeace $(2009$, p. 3) is a non-governmental organisation that attempts to attract media attention in order to gain financial donations from the general public so that they can realise their vision of "a green - ecologically healthy - and peaceful planet". (Diani \& Donati, 1999, pp. 23-24). For Greenpeace (2008), sustainability is about appreciating "our connection to the land and environment and our responsibility to take care of it for future generations". Moreover, they claim to "champion environmentally responsible and socially just solutions, including scientific and technological innovation, to protect the ability of the earth to nurture life in all its diversity" (Greenpeace, 2009, p. 3). The stated aim of Greenpeace's (2009, p. 3) environmental campaigns is to help stop deforestation; reduce greenhouse emissions; protect the oceans from illegal fishing and 
over-fishing; and to reveal any nuclear, chemical, or biological threats that may harm the environment and human health. Greenpeace's (2009, p. 12, 2010m) “defending our oceans" campaign, for example, aims to protect the ocean from over-fishing by launching "a model for sustainable and equitable tuna fisheries in the Pacific", while also encouraging businesses (such as supermarkets and other seafood markets) to implement 'sustainable' seafood policies.

Greenpeace's (2010p) sustainability narrative is materialised in their environmental campaigns, which target the 'unsustainable' or environmentally destructive practices and policies of corporations and governments with the aim of lobbying "governments and companies to implement change, ... [using] science and technology to promote solutions that are good for the environment, and [communicating] with the world to stimulate people, like you, to also take action for our shared environment". Although Greenpeace's (2010p) environmental campaigns begin with negotiations and lobbying, when these methods fail, they use non-violent direct action "as a last resort" to create a sense of urgency, apply "pressure for change", and raise awareness. Greenpeace's (2010n) “smart farming” campaign, for example, encourages the agricultural sector to incorporate sustainability into their farming methods and is calling for "policies [to be] put in place by Government to implement smart farming measures". Farming technologies and techniques, such as "nitrification inhibitors, standoff pads to collect urine, dietary changes, breed management and practices that enhance the carbon stored in the soil", are recommended by Greenpeace (2008) to help achieve 'sustainable' farming practices. 
There are at least two influential theoretical perspectives, or discursive formations (critical climatology, and deep ecology), that underpin Greenpeace's environmental protection and sustainability narratives (Luke, 2009a, p. 491; Fairclough, 1992, p. 41). First, Greenpeace's environmental sustainability narrative draws on scientific, critical climatology and climate change discourses in their attempts to reduce the amount of carbon emissions that are released into the atmosphere as a result of human activity (Luke, 2009a, p. 491). Greenpeace draw on the reports by the Intergovernmental Panel of Climate Change (2001) and other environmental scientists that connect climate change to the burning of fossil fuels and other human activities. By drawing on these reports, Greenpeace (2010b, 2010q) claim that environmentally damaging human activities, such as burning fossil fuels and "massive deforestation", are intensifying the "greenhouse effect" and so need to be "brought under control". Greenpeace (2010b) claim that the 'reality' of these environmentally damaging human activities "can be seen in melting glaciers, disintegrating polar ice, thawing permathrost, dying coral reefs, rising sea levels, changing ecosystems and fatal heat waves".

Greenpeace (2008) attributes the increasing levels of greenhouse gas emissions being released into the atmosphere to the 'unsustainable' business practices and government policies that are based on short-term economic advantages. Because these environmental risks are bound up with 'modernisation', industrialisation, and globalisation, Greenpeace (2009, p. 6) suggest that business practices and government policies need to change if the levels of carbon and greenhouse gas emissions are to be lowered (Beck, 1992, p. 21; Luke, 2010, p. 1). Within New Zealand's agricultural sector, for example, Greenpeace (2010n) claim that the corporatisation and industrialisation of 
New Zealand's agricultural sector is contributing to climate change and the rise in agricultural emissions because "trees are cut down to make way for cows and pasture, and farming becomes more intensive". Greenpeace (2010n) argue that these environmentally damaging farming practices should be changed to less intensive forms of "smart farming". To do this, Greenpeace (2010n) have called for a "moratorium on further conversion of forests into pasture", "agriculture to be brought into the Emissions Trading Scheme well before 2015,20, and for the New Zealand government to put policies in place to help "implement smart farming measures".

Second, Greenpeace draw on the ideas from the deep ecology movement ${ }^{21}$ to try and change 'unsustainable' business practices and government policies that are based on the ideas that Nature is separate from humanity and that it is simply an inanimate resource for people to utilise (Luke, 1997a, pp. 4-5). Their sustainability narrative implicitly draws on Arne Naess' (1973/2005, pp. 7-8) idea of “biospherical egalitarianism" or the idea that all things have "an equal right to live and blossom". Drawing on these ideas, Greenpeace's (2008) sustainability narrative claims that environmental sustainability is about giving and taking; it is about "how to achieve a balance between individual needs and wants, and the needs and wants of others".

Greenpeace (2008) elaborate with the use of the following analogy:

\footnotetext{
${ }^{20}$ The Emissions Trading Scheme or ETS is an attempt by the New Zealand government "to reduce the amount of greenhouse gases emitted in New Zealand. This is done by [putting a price on emissions and] charging those who emit greenhouse gases while doing certain activities" (New Zealand Government, 2010).

${ }^{21}$ Naess (1973/2005, p. 7) defines the deep ecology movement by contrasting it with shallow ecology: "the shallow ecology movement is concerned with fighting pollution and resource depletion. Its central objective is the health and affluence of people in the developed countries". Whereas, "the deep ecology movement has deeper concerns, which touch upon principles of diversity, complexity, autonomy, decentralization, symbiosis, egalitarianism, and classlessness" (Naess, 1973/2005, p. 7).
} 
Assume the planet is a person, with said needs and wants. Mainly, it wants respect and it wants to get on with doing the stuff it's used to doing and that has worked for millennia. It wants to do this without being harassed, harmed, worn down or destroyed. And it will definitely give back in return. The planet is good at giving, and we're excellent at taking from it air, water and food for starters. But taking is pretty much all we do. Rarely do we give back. And the planet is tiring of this onesided affair. It is not bullet proof and infinite yet it's being treated as such.

By setting up this "rhetorical schemata",22, which combines an analogy with a definition and description of environmental sustainability, Greenpeace (2008) then discuss whether or not New Zealand's agricultural practices conform to their conception of environmental sustainability, which is underpinned by the ideas of deep ecology (Foucault, 1972/2002, p. 63; Fairclough, 1992, p. 174). Again, Greenpeace (2010n, 2008) focus on the commercialisation and industrialisation of New Zealand's agricultural sector and how these agricultural practices take natural resources from the planet without giving anything back. They claim that because industrial farming is an intensive form of land use, it only takes from, and therefore damages, the land and waterways (Greenpeace, 2010n, 2008). In contrast to industrial farming, Greenpeace (2010n, 2010k, 2008) claim that "smart farming" or "traditional pasture farming" intertwines businesses practices and environmental concerns by "cutting down on chemicals, cutting back on herd numbers and looking after soil so that pasture thrives and lasts", which means that there is "less input, and better output".

\footnotetext{
${ }^{22}$ According to Foucault (1972/2002, p. 63), rhetorical schemata is how "groups of statements may be combined, (how descriptions, deductions, definitions, whose succession characterizes the architecture of a text, are linked together)".
} 


\section{Sustainability and Environmental Activism}

Greenpeace's sustainability narrative, then, appears to be a global civil society narrative that defends civil society and the natural environment from the state and the market by attempting to stop their environmentally damaging policies and practices. By targeting businesses and governments, Greenpeace claim that their environmental campaigns will help motivate people to support them in their attempts to stop environmental degradation and achieve an environmentally 'sustainable' society. As Anthony Giddens (2009, pp. 70-71, 119) argues, "NGOs have long regarded large corporations as the prime agents of the squandering of resources" and can play an important role in ecologically modernising ${ }^{23}$ governmental institutions and markets by pressuring them to set environmental goals and targets, and by keeping them "on the right track".

Greenpeace offer a number of, seemingly, political actions that people can take to protest against environmentally damaging practices and politicise environmental issues. That is to say, Greenpeace encourage people to raise environmental issues to the societal, structural, or institutional levels. These actions include, but are not limited to the following: volunteering and working for Greenpeace, running environmental campaigns, and joining discussions on Greenpeace's Facebook page (a social networking website) (Greenpeace, 2010c). Some of the recommended actions would require a lot of effort, while some of the other actions are small, everyday actions. Implementing and coordinating an environmental campaign, for example, potentially requires a lot of effort, time, and resources, while signing a petition or donating money does not. While signing a

\footnotetext{
${ }^{23}$ John Dryzek (as cited in Giddens, 2009, p. 70) defines ecological modernization as "a partnership in which governments, businesses, moderate environmentalists, and scientists co-operate in the restructuring of capitalist political economy along more environmentally defensible lines".
} 
petition or donating money may not be a radical form of activism or political action, these individual acts help support Greenpeace's larger, political causes that claim to bring change.

In fact, encouraging people to carry out political actions is what distinguishes Greenpeace's sustainability narrative from the MfE's and Genesis Energy's individualised sustainability narratives. The MfE and Genesis Energy encourage people to live efficiently or "smarter" by carrying out a range of apolitical actions that 'green' their existing lifestyles, whereas Greenpeace appear to encourage people to challenge 'unsustainable' business practices and government policies. Greenpeace (2010o), for example, encourage people to protest against the use of fossil fuels. In contrast, Genesis Energy (2010d) do not encourage people to protest against their use of coal and gas to generate power from the Huntly power station, but instead reassure people that it complies with resource consent requirements and that they are also involved in a "variety of community initiatives which are intended to further reduce ... [their environmental] footprint".

Politicised individualisation. However, Greenpeace's sustainability narrative is not only an attempt to encourage businesses and governments to become environmentally 'sustainable'. Although Greenpeace's sustainability narrative differs politically from the MfE's and Genesis Energy's sustainability narratives, I argue that what connects it to these two narratives is that they are simultaneously narratives about governing everyday life. Although Greenpeace (2010e) encourage people to take, seemingly, political actions against environmentally 'unsustainable' businesses and governments, their "green your life" narrative encourages people to carry out a range of apolitical actions that modify 
individual lifestyle and consumption practices. Like the MfE and Genesis Energy, Greenpeace (2010e) list a number of ideas for "how you, as an individual, can step a little lighter on the earth; how you can green your life". These ideas range from things people can do inside their house ("greener cleaning" and conserving electricity, for example), to things people can do at their place of work, such as reusing envelopes or setting up a recycling programme (Greenpeace, 2010f, 2010a).

These apolitical, 'green' practices in Greenpeace's (2010e) "green your life" narrative, environmentalise people's lives by categorising them as 'sustainable' subjects. Greenpeace (2010f) categorise people as 'sustainable' subjects by, firstly, claiming that people's everyday purchasing decisions contribute to "hazardous and toxic chemical pollution" and resource waste. While Greenpeace (2010f, 2010e) acknowledge that businesses have a larger impact on the environment compared to individuals, they also claim that everyday, 'green' actions and choices can help "reduce the impact we have on the world we live in". Indeed, Greenpeace (2010f) claim that "protecting and preserving the environment starts right in your own home". According to Greenpeace (2010e), "the heart of the environmental crisis is our consumer society" and so "the best thing that we can do for the planet is to use less of it" by reducing what you use, reusing the things you have, buying "less new stuff”, and recycling. Greenpeace (2010f) claim, for example, that most polishes and aerosol sprays "contain solvents [and gases] harmful to the environment" and so people should make their own polishes and cleaners by using ingredients (lemon juice or baking soda, for instance) that are "safer for you, those you care about, and for the environment". 
Secondly, Greenpeace claim that individual purchasing decisions and everyday practices are either directly or indirectly implicated in the release of a large amount of greenhouse gas emissions. Greenpeace's (2010q) climate change narrative focuses on the impact that burning fossil fuels (oil, coal, and natural gas) has on the "greenhouse effect"24. They claim that because a large quantity of oil, coal, and natural gas is still being burned to produce energy, "carbon dioxide concentrations in the atmosphere are now the highest in 150,000 years", which is potentially accelerating the speed of climate change (Greenpeace, 2010q). Although each individual lifestyle and purchasing decision may not be directly involved in the release of large amounts of carbon dioxide (a greenhouse gas emission), Greenpeace (20101) claims that, cumulatively, they are partially responsible for the release of a significant amount of carbon dioxide into the atmosphere. Changing incandescent lamps with compact fluorescent lamps, for example, can apparently help people save energy and help reduce greenhouse emissions (Greenpeace, 20101). Greenpeace (20101) claim that "if 1.2 million traditional bulbs were replaced with mini fluoros, and used for an average of 3 hours daily, the long term saving of greenhouse gases would be 6,000 tonnes a year ... [, which is] due to the reduction in fossil-fuel-generated electricity used to power them".

Greenpeace's individualised sustainability narrative, then, frames environmental problems as both a political problem and a technical, apolitical problem. Unlike the MfE's and Genesis Energy's individualised sustainability narratives, which govern by depoliticising environmental sustainability and sustainable consumption, people are

\footnotetext{
${ }^{24}$ The National Institute of Water \& Atmospheric Research (2008) defines the greenhouse effect as the "warming of the earth's surface and lower atmosphere caused by substances such as carbon dioxide and water vapour which let the sun's energy through to the ground but impede the passage of energy from the earth back into space".
} 
simultaneously encouraged by Greenpeace to take political and apolitical forms of action to bring about an environmentally 'sustainable' society. By supporting Greenpeace or creating their own environmental campaigns, people, Greenpeace claim, can help stop businesses and governments from being environmentally 'unsustainable'. Combined with 'green' lifestyles that minimise people's individual carbon ‘footprints', Greenpeace's political and technical, apolitical approach to sustainability constructs a model for how to live and consume 'sustainably' that is similar to the MfE's and Genesis Energy's individualised sustainability narratives, but incorporates their political activist approach to environmental problems.

However, despite framing sustainability as a larger political problem, Greenpeace's individualised sustainability narrative implicitly accepts neo-liberal understandings of sustainability that treat individuals as entrepreneurs and consumers who are responsible for environmental problems. It is therefore not 'better' or less ideological than the MfE's and Genesis Energy's sustainability narratives. As Zizek (1994, p. 61) argues, "we are in ideological space proper the moment this content [Greenpeace's sustainability narrative] - 'true' or 'false' (if true, so much better the ideological effect) - is functional with regard to some relation of social domination ('power', 'exploitation') in an inherently non-transparent way”. Protesting against 'unsustainable' business practices and government policies does not make Greenpeace's individualised sustainability narrative 'better' than the MfE's and Genesis Energy's individualised narratives. This is because all three narratives do not question or criticise forms of power that target everyday life and categorise individuals as 'sustainable' subjects (Foucault, 1982, p. 781). Neo-liberal forms of governmentality remain operative 
because its logic is not called into question (Zizek, 1994, p. 61). In other words, exposing the political dimensions of sustainability does not target techniques of power that individualise environmental responsibility.

Indeed, Greenpeace's (20101) “only planet guide” narrative potentially hegemonises individualised conceptions of environmental sustainability and sustainable consumption by accounting for their efficiency through the neo-liberal idea of "the man of enterprise and production" (people who are responsible for their life and the decisions they make) (Zizek, 2008b, p. 204; Foucault, 2008a, p. 147). Greenpeace (20101, 2010j) claim, for example, that eating less meat and dairy products will help bring about an environmentally 'sustainable' society by reducing the demand for these products and therefore the number of cows that release methane (a greenhouse gas), the amount of energy that needs to be generated, and "the amount of pesticides getting released into the environment". This statement helps account for the efficiency of individualised conceptions of sustainability through the idea that people should consume less of these products because it is "better for your body" and/or health, and will help reduce the environmental effects of agricultural practices (Greenpeace, 20101). Although Greenpeace (2008) argue that environmental sustainability and sustainable consumption are societal problems, their focus on small, everyday practices potentially stitches sustainability to the choices that responsible individuals make, rather than business practices or government policies (Zizek, 2008b, p. 205).

\section{The Green(peace) Way in Discipline}

I have discussed how Greenpeace's sustainability narrative, as an ideological doctrine, potentially individualises environmental sustainability and sustainable 
consumption by categorising individuals as 'sustainable' subjects. However, it also potentially normalises individualised conceptions of sustainable consumption by encouraging people to transform themselves through ecodisciplinary practices that performatively reproduce this conception of sustainability as a simple, everyday routine (Luke, 1999a, p. 153). Greenpeace's individualised sustainability narrative does this by outlining a number of 'green' routines and practices, and then encouraging people to incorporate them into their lives through the play of rewards.

Like the MfE, Greenpeace encourage 'sustainable' forms of living by creating a variety of routines and practices. Greenpeace (20101, 2010e) claim that "the first step to doing your bit for the climate is to change your mind" by 'greening' your life. Foucault (1977/1991a, p. 180) argued that "to punish is to exercise"; "the corrective effect expected of it ... is achieved directly through the mechanics of training". Similarly, as Greenpeace illustrate (20101), the corrective effect of living 'sustainably' is not simply achieved by 'changing your mind', but by training people through a number of small, corrective routines.

Analysed as a disciplinary narrative that breaks down everyday life so that it can be 'greened', Greenpeace divide the various facets of everyday life into three broad categories (Foucault, 2007, p. 56). The first area of life that Greenpeace (2010f) claim can be 'greened' is the area of household cleaning. As discussed above, people are enjoined to clean 'sustainably' or 'greener' by making their own cleaning products using ingredients that are allegedly 'better' for the environment (Greenpeace, 2010f). The second area of life that Greenpeace (2010e) claim can be 'greened' is the home, more specifically, the kitchen, bathroom, laundry, as well as the outside areas of the home. 
People are encouraged, for example, to use energy efficient electrical appliances, eat less meat, compost food scraps, save water, and grow vegetables (Greenpeace, 2010j). The final area of life that Greenpeace (2010a) claim can be greened is people's practices and routines in their place of work. People are encouraged to reduce the amount of paper they use by photocopying or printing on both sides of the page, using office supplies that are 'eco-friendly', and adopting other 'green' practices and routines (establishing a recycling program, using a ceramic coffee cup, and using public transport to get to and from work, for example).

By 'greening' everyday life, Greenpeace potentially normalise individualised conceptions of sustainability by, firstly, establishing a division between 'normal' and 'abnormal' forms of sustainability. Greenpeace's (2010e) idea of a 'green' or ‘sustainable' life normalises individualised understandings of sustainability by distributing areas of everyday life and consumption habits into environmentally 'positive' and environmentally 'negative' categories (Foucault, 1977/1991a, p. 180). As discussed above, Greenpeace encourage people to become political, 'sustainable' subjects by suggesting that they should do volunteer work or run environmental campaigns. However, these ideas become eclipsed by the easier, apolitical options (donating to Greenpeace or 'greening' everyday routines, for instance) that they offer. The lengths that Greenpeace go to in their outline of how people can 'green' their everyday lives combined with the ease in which 'green' practices can be incorporated into everyday life, helps normalise individualised conceptions of living and consuming 'sustainably'. In their narrative, individualised, apolitical conceptions of sustainability are normal because they can be easily achieved, whereas political conceptions of sustainability are abnormal 
because they require a lot more time and effort to achieve. As Luke (1997a, p. 127) argues, every individual and consumer wants to hear that "ecological salvation is possible 'without effort' and 'with very little thought'".

Secondly, by encouraging people to carry out everyday routines, Greenpeace's narrative helps normalise individualised conceptions of sustainability through the operation of rewards and punishments (Foucault, 1977/1991a, p. 181). Like Genesis Energy's disciplinary narrative, Greenpeace's (2010e) "green your life” narrative rewards people with the promise of a 'clean and green' environment, and punishes people by taking this promise away (Foucault, 1977/1991a, p. 181). This can be seen in Greenpeace's (2010e) assertion that 'green' routines and practices will help people "step a little lighter on the earth". Greenpeace's (2010a) claim, for example, that "the world's ancient forests (eg [sic], in Papua New Guinea and the Amazon) are being stripped away for many disposable paper products you can find at home and at work, such as toilet paper, phone books, newsprint and writing paper", punishes people through the idea that their everyday routines are environmentally destructive (signified by the word “stripped”). But Greenpeace's (2010a) narrative also rewards people with the promise of a 'clean and green' environment if they reduce the amount of paper they use and/or begin buying "recycled, chlorine-free paper". The play of these simple rewards and punishments help normalise individualised conceptions of sustainability by suggesting to people that the more areas of their life that they can 'green', the more environmentally 'sustainable' society will become. Whether it was intended or not, the various areas of life that have been 'greened' by Greenpeace functions as an "optimal model" for how to 
be 'sustainable' and so the 'normal' is that which conforms to the model or norm and the abnormal is that which departs from it (Foucault, 2007, p. 57).

\section{Virtual Consumption, Interpassivity, and Sustainable Living}

Throughout this chapter I have discussed how Greenpeace's sustainability narrative normalises individualised conceptions of sustainability. In this section, I discuss how Greenpeace frame sustainability as a practice of the self that not only removes the risky and excessive dimensions from everyday life that impact on the natural environment, but also sustains the ideological fantasy of living and consuming without the risk of environmental intrusion, which helps normalise individualised conceptions of sustainability. Like Genesis Energy and the MfE, Greenpeace encourage people to turn themselves into subjects who are environmentally 'sustainable' by framing everyday 'sustainable' actions as a practice of the self that removes the excessive dimensions from living and consuming (Foucault, 2000b, p. 291; Zizek, 2004, p. 507).

On one level, Greenpeace's (2010e) sustainability narrative frames living and consuming 'sustainably' as a prohibitive technology of the self that not only removes the 'unsustainable' dimensions from everyday life that impact upon the natural environment, but also develops and transforms individuals into 'sustainable' subjects and political consumers (Foucault, 2000b, p. 291; Beck, 2005, p. 237). Their practices of the self potentially transform 'unsustainable' consumers into political consumers who "[possess] the global power of refusal, of non-purchase ... [or] 'consumer strike'”, what Beck (2005, pp. 7, 237) calls a "counter-power of global civil society". For Greenpeace (2010e, 2010j), living and consuming 'sustainably' means resisting consumerism and being more self-sufficient by reducing what you use, buying "less new stuff", reusing, recycling, 
growing your own vegetables, eating less meat, and making your own cleaning products (to list some of their main suggestions).

Greenpeace (2010e) encourage people to refuse the environmentally damaging effects of consumerism by adopting, what Smart (2010, p. 63) calls, a "“consumerist vision' of the world" 25 , where consumers can resist consumerism through their buying decisions. Beck (2005, pp. 237-238) argues that, apart from the difficulty of organising consumer resistance, the political consumer's "counter-power" of non-purchase can potentially "[break] the power of transnational capital by buying this product instead of that product”. Greenpeace implicitly draw on Beck's (2005) idea of consumer “counterpower" and encourage people to utilise market and consumer-based logic to resist consumerism (Grey \& Nickel, 2009). Greenpeace's (2010e) supporters, then, are encouraged to transform themselves through their 'sustainable' or 'green' practices of the self so that they can become environmentally 'sustainable' subjects and political consumers who resist "our consumer society" by consuming and recycling their way out of it (Grey \& Nickel, 2009).

There are problems, however, with the idea of resisting consumerism through political consumption. One main problem with this idea is that it tends to reduce politics to consumer choice. While Beck's (2005) idea of consumer 'counter-power' might be political in the sense that it politicises consumer choices and encourages resistance and social change, it is problematic in the sense that it reduces politics to consumer choice,

\footnotetext{
${ }^{25}$ More specifically, it is a vision "which portrays consumers exercising a significant degree of power and influence over economic life and depicts consumer culture as simply representing what it is consumers have demanded, what 'sovereign' consumers want and have freely elected to choose" (Smart, 2010, p. 63). Smart's (2010, p. 31) idea is similar to consumer 'sovereignty', which attributes "a dominant economic role to the consumer and [serves] to legitimate the idea of the 'free market', within which unimpaired choice could be exercised by 'sovereign' consumers".
} 
that is to say, "individuated responses to individual needs" (J. Dean, 2009, p. 11).

Therefore, Beck's idea of political consumption seems to ignore the important role that marketing and advertising plays in transforming 'green' and other forms of political consumption into new forms of consumeristic behaviour (Luke, 1997a, pp. 129-130). Moreover, consumer choice, as Smart (2010, p. 33) argues, is subject to an entire range of other important influences that are not freely chosen by the individual consumer, such as manufacturing, retailing, and fair trade and environmental campaigns.

But Greenpeace's narrative does not simply frame living and consuming 'sustainably' as a prohibitive practice of the self that helps counter the 'unsustainable' practices and policies of businesses and governments. The everyday, 'sustainable' actions in Greenpeace's narrative are also underpinned by the ideological fantasy of living and consuming without the risk of environmental intrusion. Like Genesis Energy's (2010f) conception of sustainability, Greenpeace's sustainability narrative is not only an attempt to stop environmental degradation, but is also an injunction to enjoy a life free from risk and environmental intrusion (Zizek, 2004, pp. 508-509). Their focus on living a life free from risk, as Beck (1992, p. 88) argues, is connected to reflexive, risk societies and "the emergence of individualized forms and conditions of existence, which compel people ... to make themselves the centre of their own planning and conduct of life". An increasing number of people, according to Beck (1992, p. 88), have to choose certain social identities and ways of life while also "[taking] the risks in doing so".

However, Greenpeace do not simply encourage people to change their environmentally damaging lifestyles; they encourage people to 'green' their existing lifestyles. Greenpeace's injunction to enjoy a life free from risk is not only linked to 
Beck's (1992) idea of a reflexive, risk society, but is also connected to Zizek's (2008b, pp. 236-237) conception of post-politics, where an idea is 'good' if it 'works' "within the framework of existing sociopolitical relations" ${ }^{26}$. In contrast to a post-political act, Zizek (2008b, p. 237) argues that "the political act (intervention) proper is not simply something that works well within the framework of the existing relations, but something that changes the very framework that determines how things work". According to J. Dean (2009, p. 14), Zizek is arguing that "what makes the contemporary setting post-political is the exclusion of the possibility of politicization", where a particular issue or event is situated within "a series of problems that confront the system as a whole". For instance, rather than sustainable consumption being a particular problem for certain businesses and individuals, it is a structural problem that is connected to a number of other problems, such as over-consumption, development, and climate change.

Although the idea of post-politics can be problematic if it is used to describe the absence of politics and political ideas, I use it here to analyse how civil society sustainability narratives almost mirror sustainability narratives that are generated within the spheres of the state and the market (J. Dean, 2009, p. 12). Rather than sustainability being a political intervention that changes how people live through transformations in broader social and institutional practices, Greenpeace's narrative, like Genesis Energy's narrative, suggests that minor changes in individual lifestyle and consumption habits will help reduce the impact that individual practices have on the environment.

\footnotetext{
${ }^{26}$ Zizek (2008b, p. 237) explains that "to say that good ideas are 'ideas that work' means that one accepts in advance the (global capitalist) constellation that determines what works (if, for example, one spends too much money on education or healthcare, that 'doesn't work', since it infringes too much on the conditions of capitalist profitability)".
} 
Greenpeace's (2010a, 20101) post-political approach to sustainability is outlined in their "only planet guide" and "at work" narrative, which explains how a person's work practices and mode of transportation can be 'greened'. Greenpeace (2010a, 20101) suggest that if people 'green' their work practices and routines then they will not have to worry about changing occupations or working for a 'green' industry because they will be reducing "the impact on our environment at work". In other words, you can still work "at a factory that may be blatantly polluting the environment", just so long as you recycle paper or set up a recycling program (Greenpeace, 2010a). Next, Greenpeace (20101) describe how people can "drive smarter" if they "can do the following: stop at the red light with minimal braking; maintain smooth and constant rev's per minute; coast in neutral when driving down hill (manual cars only); keep to the speed limit, and when you replace your car get one that uses less gas". Although they recommend using public transport instead of a private vehicle, Greenpeace (20101) claim that driving "smarter" can also help "save the climate" and "save money on gas", which suggests that people can continue to enjoy their current lifestyle without an environmental catastrophe intruding and taking it away.

What differentiates Greenpeace's narrative from Genesis Energy's and the MfE's narratives, is that they use the act of charitable donation as an injunction to enjoy a life free from risk and environmental intrusion. Greenpeace do this by framing charitable donation as a way of living and consuming without risk. First, donating money to Greenpeace (2010g) through their "Greenpeace Giving" website is a form of risk-free consumption because it gives someone (a friend or relative, for instance) a card "with a 
message inside about the gift you have bought them and how this gift will help save the environment". Greenpeace (2010h) explain that:

When you buy a Greenpeace gift, we don't actually giftwrap a lifejacket and deliver it Santa-like to an activist on the ocean. Instead, the money goes to funding the activities like that of the environmental campaign that your gift represents. And your friend receives a card describing how your present is helping the planet.

In other words, Greenpeace (2010g) draw on consumer focused measures, such as donating money or buying virtual gifts, as a way of securing a way of life that is free from the risk of environmental intrusion. The virtual gift of "wind power", for example, is one way that people can live without having to make any significant changes to their lives. With the virtual gift of "wind power", people can continue to enjoy "wind-powered Christmas lights, a wind-powered Esky for those long afternoons on the beach, a windpowered TV to watch wind-powered Christmas special repeats" (Greenpeace, 2010d).

Second, as a way of living without risk, donating money to Greenpeace through their "Greenpeace Giving" website is a form of interpassive, 'sustainable' living, where people can live 'sustainably' through Greenpeace, who achieve environmental sustainability for them while they can enjoy a risk-free life (Zizek, 1998, p. 143). As Maniates (2001, pp. 42-43) argues, donating money is an individualised form of environmental action that suggests to people that they should act, so long as they "don't get in the way". This can be seen in Greenpeace's (2010i) idea that:

Not all of us can get to the Southern Ocean or occupy forests that are being cut down to make way for corporate dairy farms. But we can still do 
things to help! Like supporting Greenpeace financially so we can continue to go that extra mile.

The idea of interpassivity also permeates Greenpeace's understanding of environmental activism. Figure 2 depicts an 'armchair activist' or a person who is living a risk-free life because they have, supposedly, donated money to Greenpeace (2010i), who then attempt to bring about an environmentally 'sustainable' planet and society. The image depicts a person holding a mug while sitting in an armchair that is situated within a forest. On one level, the person in the armchair connotes an 'armchair activist' who is environmentally active through Greenpeace. The placement of the armchair within the forest juxtaposes passive forms of action, such as charitable donation, with environmentalism. The image suggests that people can protect the environment without sacrificing the comforts of their home, which is signified by the person relaxing in an armchair that is nestled within a forest. Moreover, when analysed metonymically, the person in the armchair represents Greenpeace. Because Greenpeace rely on donations from individuals, the image of the person in the armchair suggests that individuals make it possible for Greenpeace to actively protect the environment. That is to say, through the act of charitable donation, individuals protect the environment through Greenpeace. However, the image also suggests that after donating money to Greenpeace, you can then relax in your reclining armchair, drink a hot (or cold) beverage, and enjoy a life free from risk or environmental problems (signified by the 'clean and green' forest in the background). In this sense, 'armchair activists' are active through Greenpeace, who help protect the environment for them while they enjoy a life free from the risk of environmental intrusion. 


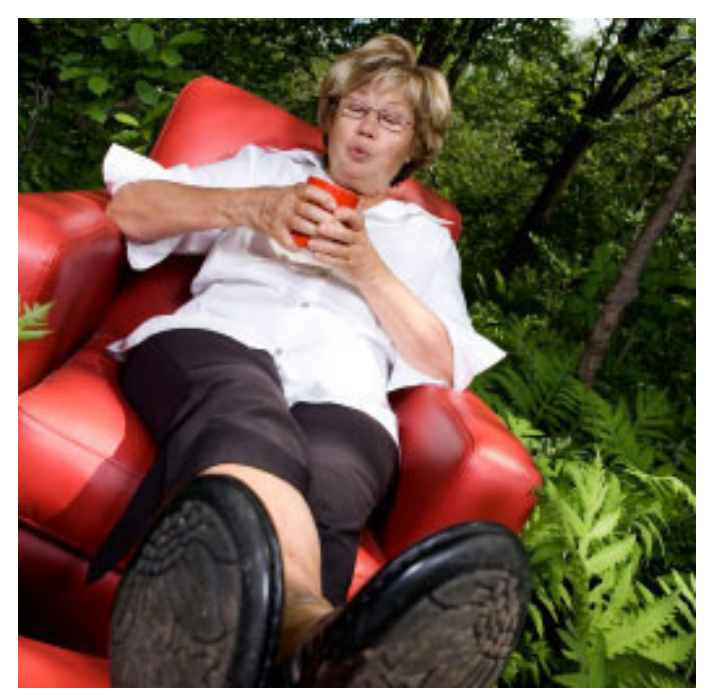

Figure 2. "Armchair activism" (Greenpeace, n.d.).

To summarise, Greenpeace's criticisms of environmentally damaging business practices and government policies suggest that their environmental and sustainability narratives are opposed to the narratives that are generated within the economic and political spheres. However, as I have argued, their sustainability narrative, whether it is intended or not, has the effect of producing normalised 'sustainable' subjects who, instead of being opposed to the market and the state, are aligned with the MfE's and Genesis Energy's ideas of 'sustainable' living. The individualisation of environmental sustainability and sustainable consumption is not simply limited to state and market narratives, but is also at the heart of Greenpeace's sustainability narrative. Like the MfE and Genesis Energy, Greenpeace categorise individuals as 'sustainable' subjects, and set up subject positions through disciplinary practices and practices of the self. However, unlike the MfE and Genesis Energy, Greenpeace encourage political forms of 'sustainable' living. Yet, despite their focus on the political dimensions of 'sustainable' 
living, they reproduce individualised conceptions of sustainability by focusing on interpassive and consumer oriented forms of living and consuming. 


\section{Conclusion}

'Sustainable' governing practices have the potential to affect and transform a wide range of existing environmental, economic, and social practices and relations. Here, I have analysed the narrative shared by the state, market, and civil society by focusing on the emergence of sustainability as a practice and narrative of governance and selfregulation within the context of neo-liberal and individualised governing practices. I argued that the concept of sustainability has entered into the practices of governance and underlying governing narratives as a form of governmentality that appears to regulate and environmentalise everyday human conduct. I claimed that the MfE, Genesis Energy, and Greenpeace's sustainability narratives govern by encouraging people to live and consume according to seemingly unalterable neo-liberal and individualised understandings of the environment and sustainability. I did this by arguing that in all three supposed spheres, individuals are categorised and positioned as 'sustainable' subjects through largely apolitical and technical conceptions of environmental problems, disciplinary practices, and practices of the self that appear to remove risk from the act of consumption and everyday life.

In the first chapter, I situated my argument by discussing the concept of sustainable consumption and its links with environmentalism, governmentality, and neoliberalism. This chapter also outlined how the idea of sustainability has entered into narratives about governing. In chapter two, I situated my argument theoretically by combining Zizek's three dimensional conception of ideology with Luke's concept of environmentality and Foucault's conceptions of governmentality and power. I combined these different concepts to discuss how people are encouraged to live and consume 
according to a governmentalised understanding of sustainability. I then described how I would employ, methodologically, my theoretical framework by outlining Fairclough's critical discourse analysis, which incorporates Foucaultian discourse analysis and ideology critique, and discussing why I chose the MfE, Genesis Energy, and Greenpeace's narratives as my analytical focus.

The three dimensions of my argument were applied to each narrative in order to discuss how the three narratives differed. In chapter three, I analysed the practices and narratives of state governance. I began with a discussion of how sustainability functions within the practices of state governance by focusing on state autonomy theory and structuralist theories of the state. As I discussed in this chapter, through the lens of state autonomy theory, sustainability appears to have entered into the practices of state governance as part of the growing role that the state plays in controlling and managing natural resources and environmental issues. While, through the lens of structuralist theories, the emergence of sustainability within state governance practices appears to help maintain and stabilise capitalist economies while mediating the demands and struggles from within civil society. Although the MfE's narrative can be analysed through these two theories, it also has the effect of governing the population at the individual level. The MfE's narrative appears to indirectly shape individual and business responsibilities through environmentalised disciplinary practices and practices of the self that encourage people and businesses to consume and produce without constraint and/or environmental risk. In other words, it positioned individuals as 'sustainable' subjects who are responsible for consuming and producing 'sustainably'. 
The MfE's disciplinary practices positioned individuals as 'sustainable' subjects by normalising sustainability as a simple, everyday routine, while their practices of the self framed sustainability as a practice that sustains the imaginary identities of the 'free' business and consumer who can produce and consume without constraint. Rather than trying to convince people that their everyday 'sustainable' practices will achieve environmental sustainability, the MfE's practices of the self bypassed this problem and framed sustainability within the fantasy of consumption and production without risk. That is to say, people do not need to believe in environmental sustainability in order to become ‘sustainable' subjects.

Like the MfE's narrative, Genesis Energy's sustainability narrative appeared to be a narrative of governing the population at the individual level. Their narrative drew on the ideas from ecocommercialism and 'green' consumerism discourses, in what appeared to be an attempt to become an efficient, 'sustainable' business and to tap into 'green' consumer markets. However, as I argued in chapter four, Genesis Energy's sustainability narrative was also a narrative of environmentality that encourages their customers to reduce their greenhouse gas emissions and environmental footprint. Like the MfE, Genesis Energy's narrative appeared to shape individual responsibilities through environmentalised disciplinary practices and practices of the self, but instead of encouraging people to consume without constraint and/or risk, people were encouraged to live and consume 'sustainably' so that they could enjoy their current lifestyle and financial freedom.

Greenpeace's sustainability narrative appeared to take a different approach to the MfE's and Genesis Energy's narratives. I analysed their narrative as a global civil society 
narrative that attempts to protect civil society and the environment from environmentally 'unsustainable' business practices and government policies. In their critique of 'unsustainable' farming practices and policies, Greenpeace's sustainability narrative drew on the ideas of critical climatology and deep ecology, and claimed that these practices and policies are degrading the land and waterways within New Zealand and are contributing to climate change. However, because Greenpeace are concerned with climate change and reducing resource waste, they also appeared to regulate everyday life by encouraging individual's to adopt everyday, 'green' practices. So, while Greenpeace 'exposed' the political dimensions of sustainability they did not question techniques of power that individualise environmental responsibility. Indeed, like Genesis Energy, Greenpeace's narrative appeared to shape individual responsibilities through disciplinary practices and practices of the self that 'green' people's everyday practices so that they can continue to enjoy their current lifestyle. Although Greenpeace took seemingly political approaches to addressing environmental problems, they also encouraged individuals to adopt post-political forms of action that are aligned with the MfE's and Genesis Energy's apolitical and technical approaches to sustainability, which, as I demonstrated, helps reproduce individualised conceptions of sustainability.

What emerges from this analysis is that individualised forms of sustainability appear to be indirect attempts at limiting and distributing risks without limiting, what Beck (1992, p. 19) calls, the "modernization process", and, what Luke (2006b, p. 103) calls, "higher material output goals". It is as though sustainability has emerged not as an attempt to eliminate 'unsustainable' practices, but as an attempt to normalise certain practices that render individuals responsible for minimising risk, so that the population's 
‘sustainability' and impact on the environment can be known and managed efficiently. This was highlighted within all three narratives that I analysed. For example, Greenpeace's (20101) claim that "if 1.2 million traditional bulbs were replaced with mini fluoros, and used for an average of 3 hours daily, the long term saving of greenhouse gases would be 6,000 tonnes a year", fits with the MfE's (2010d) claim that "small, yet significant actions ... can save money and improve health, while fighting climate change and protecting local environments".

While, in terms of form, these three narratives differed politically, in terms of content, they all shared a belief that sustainable consumption and environmental sustainability are primarily technical issues of reducing carbon emissions, consuming fewer natural resources while also consuming them efficiently or responsibly, and reducing the amount of environmental pollution. These technical understandings of sustainability underpinned the three state, market, and civil society narratives I analysed and legitimised the idea that individuals play a large role in ensuring an environmentally 'sustainable' economy and society. However, this individualised approach to sustainability was not simply justified and explained with reference to technical and neoliberal understandings of environmental problems. It was also normalised as an individual problem through material disciplinary practices that performatively reproduce individualised conceptions of sustainability and practices of the self that sustain the ideological fantasy of living and consuming without environmental risk. These practices potentially reproduce individualised conceptions of sustainability by encouraging individuals to become responsible and 'efficient' subjects. 
Although the findings of my research are limited to the three narratives analysed here, a larger corpus could contribute to understanding, in greater detail, the relationships between sustainability, governmentality, and the environmentalisation of human conduct (Fairclough, 1992, p. 226). Further research is needed to analyse how sustainability narratives differ within the state, market, and civil spheres. For instance, there might be important differences between Greenpeace's approach to environmental problems and the various environmental critiques that are developed by other NGOs, communities, and individuals within civil society. Moreover, this research has implicitly raised the issue of the relationships between sustainability, environmentalism, and resistance. That is to say, the environmentalisation of everyday practices seems to blunt forms of resistance and environmental critiques of 'unsustainable' governments and businesses. While I have focused on Greenpeace's environmental critique, further research might explore the idea of sustainability as a practice of resistance.

To conclude, then, the governmentalisation of sustainability is common to all three narratives analysed here and produced similar effects within the three spheres. Within the state sphere, individualised and governmentalised forms of sustainability can be located within the shift to what M. Dean (2010, p. 207) calls reflexive forms of national government that reform the performance of existing governmental institutions, practices, and techniques by "folding back ... the objectives of government upon its means" and making them "operable through the activation of the energies and capacities of existing agencies and institutions". Within the economic and civil spheres, these two forms of sustainability are connected with the governmentalisation of the market and civil society. Genesis Energy's and Greenpeace's sustainability narratives not only 
'reflexively' govern their operations and practices, but also help govern the population at the individual level. In other words, all three narratives appear to govern the population at the individual level by positioning individuals as responsible, 'sustainable' subjects.

These three narratives, therefore, cannot be simply described as either narratives of governance or narratives of self-regulation. They resemble forms of governmentality or more precisely environmentality that incorporate the ideas of governance and selfregulation so that the population can be managed at the collective and individual levels. They have the effect of indirectly governing everyday life through 'sustainable', everyday practices, which helps regulate the population according to apolitical and technical conceptions of a 'sustainable' economy and society. That is to say, the population's impact on the environment can be managed by 'greening' individual and business practices. Whether it is intended or not, by focusing on individual practices the three narratives share the same individualised narrative that positions individuals as 'sustainable' subjects. 


\section{References}

Abercrombie, N., Hill, S., \& Turner, B. S. (2000). The penguin dictionary of sociology (4th ed.). London, England: Penguin Books.

Alexander, J. C. (2006). The civil sphere. Oxford, England: Oxford University Press.

Althusser, L. (1984). Essays on ideology. London, England: Verso.

Auckland Sustainable Cities Programme. (2006). Success in sustainability. Retrieved 11 June, 2010, from http://www.sustainableauckland.govt.nz/download/ASCP_2006.pdf

Babbie, E. (2007). The practice of social research (11th ed.). Belmont, CA: Thomson/Wadsworth.

Barnett, C., Cloke, P., Clarke, N., \& Malpass, A. (2005). Consuming ethics: Articulating the subjects and spaces of ethical consumption. Antipode, 37(1), pp. 23-45. Retrieved from http://oro.open.ac.uk/7144/1/Consuming_ethics_Antipode_revision1.pdf

Barrow, C. W. (1993). Critical theories of the state: Marxist, neo-Marxist, post-Marxist. Madison, WI: The University of Wisconsin Press.

Barry, J. (2007). Environment and social theory (2nd ed.). Oxon, England: Routledge.

Barthes, R. (2001). Mythologies. Paris, France: Seuil.

Bodley, J. H. (2008). Anthropology and contemporary human problems (5th ed.). Lanham, MD: AltaMira Press. 
Bratsis, P. (2002). Unthinking the state: Reification, ideology, and the state. In S.

Aronowitz, \& P. Bratsis, Paradigm lost: State theory reconsidered (pp. 247-267).

Minneapolis, MN: University of Minnesota Press.

Beck, U. (1992). Risk society: Towards a new modernity. London, England: SAGE.

Beck, U., \& Beck-Gernsheim, E. (2002). Individualization: Institutionalized

Individualism and its social and political consequences. London, England: SAGE.

Beck, U. (2005). Power in the global age: A new global political economy. Cambridge, England: Polity Press.

Beck, U. (2010). Climate for change, or how to create a green modernity? Theory, Culture \& Society, 27(2-3), 254-266. Retrieved from http://tcs.sagepub.com/content/27/2-3/254

Beehive.govt.nz. (1996). Environment 2010 strategy. Retrieved June 10, 2010, from http://beehive.govt.nz/feature/environment+2010+strategy

Beehive.govt.nz. (2007). Budget 2007. Retrieved June 10, 2010, from http://www.beehive.govt.nz/feature/budget+2007+sustainability

Charlie's. (2010). Water. Retrieved January 18, 2010, from http://www.charlies.co.nz/\#products/Water

Cohen, J. L., \& Arato, A. (1992). Civil society and political theory. Cambridge, England: MIT Press.

Craib, I. (1992). Modern social theory: From Parsons to Habermas (2nd ed.). England: Pearson Education Limited.

Danaher, G., Schirato, T., \& Webb, J. (2000). Understanding Foucault. Sydney, Australia: Allen \& Unwin. 
Dann. C. (2003). The environmental movement. In R. Miller (Ed.), New Zealand Government and politics (3rd ed.) (pp. 368-377). Auckland, New Zealand: Oxford University Press.

Dean, J. (2006). Zizek’s politics. London, England: Routledege.

Dean, J. (2008). Enjoying neoliberalism. Cultural Politics 4(1), 47-72. Retrieved from http://jdeanicite.typepad.com/i_cite/files/neoliberal_fantasy_article.pdf

Dean, J. (2009). Democracy and other neoliberal fantasies: Communicative capitalism and left politics. Durham, NC: Duke University Press.

Dean, M. (2010). Governmentality: Power and rule in modern society (2nd ed.). Los Angeles, CA: SAGE.

Diani, M. \& Donati, P. R. (1999). Organisational change in Western European environmental groups: A framework for analysis. In C. Rootes (Ed.), Environmental movements: Local, national and global (pp. 13-34). London, England: Frank Cass.

Ehrenberg, J. (1999). Civil society: The critical history of an idea. New York, NY: New York University Press.

Eikenberry, A. M., \& Nickel, P. M. (2006). Towards a critical social theory of philanthropy in an era of governance. Unpublished manuscript.

Esty, D. C., Levy, M., Srebotnjak, T. \& de Sherbinin, A. (2005). 2005 environmental sustainability index: Benchmarking environmental stewardship. New Haven, CT: Yale Center for Environmental Law and Policy. 
Evans, P. B., Rueschemeyer, D., \& Skocpol, T. (1985). Preface. In P. B. Evans, D. Rueschemeyer, \& T. Skocpol (Eds.), Bringing the state back in (pp. vii-x). Cambridge, England: Cambridge University Press.

Fairclough, N. (1992). Discourse and social change. Cambridge, England: Polity Press. Fairclough, N. (1995). Media discourse. London., England: Edward Arnold.

Fairclough, N., \& Wodak, R. (1997). Critical discourse analysis. In T. A. van Dijk, Discourse as social interaction (pp. 258-284). London, England: SAGE.

Fairclough, N. (2001). The discourse of new labour: Critical discourse analysis. In M. Wetherell, S. Taylor, \& S. J. Yates (Eds.), Discourse as data: A guide for analysis (pp. 229-266). London, England: SAGE.

Flyvbjerg, B. (1998). Habermas and Foucault: Thinkers for civil society? British Journal of Sociology, 49(2), 210-233. Received from http://www.jstor.org/stable/591310

Foucault, M. (1980a). Body/power. In C. Gordon (Ed.), Power/knowledge: Selected interviews and other writings 1972-1977 (pp. 55-62). New York, NY: Pantheon Books.

Foucault, M. (1980b). Truth and power. In C. Gordon (Ed.), Power/knowledge: Selected interviews and other writings 1972-1977 (pp. 109-133). New York, NY: Pantheon Books.

Foucault, M. (1982). The subject and power. Critical Enquiry, 8(4), 777-795. Retrieved March 25, 2010, from JSTOR database http://www.jstor.org/stable/1343197 Foucault, M. (1983). On the genealogy of ethics. In H. L. Dreyfus \& P. Rabinow, Michel 
Foucault: Beyond structuralism and hermeneutics (pp. 229-252). Chicago, IL: The University of Chicago Press.

Foucault, M. (1988). Technologies of the self. In L. H. Martin, H. Gutman, \& P. H. Hutton (Eds.), Technologies of the self: A seminar with Michel Foucault (pp. 1649). Amherst, MA: University of Massachusetts Press

Foucault, M. (1991a). Discipline and punish: The birth of the prison/translated from the French by Alan Sheridan. London, England: Penguin. (Original work published 1977)

Foucault, M. (1991b). Governmentality. In G. Burchell, C. Gordon, \& P. Miller (Eds.), The Foucault Effect: Studies in Governmentality: With two lectures by and an interview with Michel Foucault (pp. 87-104). Chicago, IL: University of Chicago Press.

Foucault, M. (2000a). Subjectivity and truth. In P. Rabinow (Ed.), Michel Foucault: Ethics: Subjectivity and truth/translated by Robert Hurley and others (pp. 87-92). London, England: Penguin.

Foucault, M. (2000b). The ethics of the concern for self as a practice of freedom. In P. Rabinow (Ed.), Michel Foucault: Ethics: Subjectivity and truth/translated by Robert Hurley and others (pp. 281-301). London, England: Penguin.

Foucault, M. (2002). The archaeology of knowledge/translated from the French by A. M. Sheridan Smith. London, England: Routledge. (Original work published 1972) Foucault, M. (2004). Society must be defended: Lectures at the College De France, 1975- 
1976/edited by Mauro Bertani and Alessandro Fontana; general editors, Francois Ewald and Alessandro Fontana; English series editor, Arnold I. Davidson; translated by David Macey. London, England: Penguin.

Foucault, M. (2007). Security, territory, population: Lectures at the Collège de France, 1977-1978/edited by Michel Senellart; general editors, François Ewald and Alessandro Fontana; English series editor, Arnold I. Davidson; translated by Graham Burchell. Hampshire, England: Palgrave Macmillan.

Foucault, M. (2008a). The birth of biopolitics: Lectures at the Collège de France, 197879/edited by Michel Senellart; general editors, François Ewald and Alessandro Fontana; English series editor, Arnold I. Davidson; translated by Graham Burchell. Hampshire, England: Palgrave Macmillan.

Foucault, M. (2008b). The history of sexuality, Volume 1: The will to knowledge/translated from the French by Robert Hurley. Australia: Penguin. (Original work published 1978)

Genesis Energy. (2009). Annual report 2009. Retrieved August 20, 2010, from http://ebooks.norcross.co.nz/GE-Annual-Review-2009/download.pdf Genesis Energy. (2010a). Balancing sustainability with profitability. Retrieved August 20, 2010, from http://www.genesisenergy.co.nz/genesis/trade/sustainability/sustainability_home.c $\mathrm{fm}$

Genesis Energy. (2010b). Climate change. Retrieved August 20, 2010, from http://www.genesisenergy.co.nz/genesis/responsibility/climate-change/climatechange \$.cfm 
Genesis Energy. (2010c). Community. Retrieved August 20, 2010, from

http://www.genesisenergy.co.nz/genesis/responsibility/community/community_ho me.cfm

Genesis Energy. (2010d). Environmental effects. Retrieved August 20, 2010, from http://www.genesisenergy.co.nz/genesis/index.cfm?B8A9091B-5056-AC664C38-ABAF9ACDA01A

Genesis Energy. (2010e). Our generation sites. Retrieved August 20, 2010, from http://www.genesisenergy.co.nz/genesis/generation/our-generation-sites/ourgeneration-sites_home.cfm

Genesis Energy. (2010f). Pukeko - Climate change. Retrieved August 20, 2010, from http://www.genesisenergy.co.nz/genesis/index.cfm?6D772936-0663-567B-41A7A79C4B44A0E7

Genesis Energy. (2010g). Pukeko - Generation diversity. Retrieved August 20, 2010, from http://www.genesisenergy.co.nz/genesis/index.cfm?6D772936-0663-567B-41A7A79C4B44A0E7

Genesis Energy. (2010h). Reducing our footprint. Retrieved August 20, 2010, from http://www.genesisenergy.co.nz/genesis/index.cfm?B8AAD688-5056-AC664C4B-93236C534B9B

Genesis Energy. (2010i). Save energy at home. Retrieved August 20, 2010, from http://www.genesisenergy.co.nz/genesis/index.cfm?F125E610-CD42-ACE76710-ADBF89F3093B 
Genesis Energy. (2010j). Waikato rivercare. Retrieved August 20, 2010, from http://www.genesisenergy.co.nz/genesis/index.cfm?12D2B5D5-EC25-58FBB634-0FC54B26C164

Genesis Energy. (2010k). We can make a difference to tomorrow. Retrieved August 20, 2010, from http://www.genesisenergy.co.nz/genesis/index.cfm?A71A19A0FAE0-E4F4-B7B7-B469AD2D640F

Giddens, A. (2009). The politics of climate change. Cambridge, England: Polity Press. Goldfinch, S. (2003). The state. In R. Miller (Ed.), New Zealand Government and politics (3rd ed.) (pp. 547-556). Auckland, New Zealand: Oxford University Press.

Good magazine. (2010). The good shopping handbook. Retrieved June 10, 2010, from http://good.net.nz/goodbook/

Greenpeace. (n.d.). Armchair activism [image]. Retrieved October 9, 2010, from http://www.greenpeacegiving.org.nz/Product.php?pid=6\&navcat=3\&navsub=0

Greenpeace. (2008). The s word. Retrieved October 9, 2010, from http://www.greenpeace.org/new-zealand/en/about/e-mag-OLD/summer-2008/thereal-meaning-of-sustainabi/

Greenpeace. (2009). Greenpeace New Zealand annual report 2009. Retrieved October 9, 2010, from http://www.greenpeace.org.nz/annual-report/2009/

Greenpeace. (2010a). At work. Retrieved October 9, 2010, from http://www.greenpeace.org/new-zealand/en/take-action/green-your-life/at-work/ Greenpeace. (2010b). Climate impacts. Retrieved October 9, 2010, from http://www.greenpeace.org/new-zealand/en/campaigns/climate-change/impacts/ Greenpeace. (2010c). Get involved. Retrieved October 9, 2010, from 
http://www.greenpeace.org/new-zealand/en/take-action/

Greenpeace. (2010d). Gifts for climate future: It's a breeze to make a difference.

Retrieved October 9, 2010, from

http://www.greenpeacegiving.org.nz/Product.php?pid=29\&navcat=1\&navsub=5

Greenpeace. (2010e). Green your life. Retrieved October 9, 2010, from

http://www.greenpeace.org/new-zealand/en/take-action/green-your-life/

Greenpeace. (2010f). Greener cleaning. Retrieved October 9, 2010, from

http://www.greenpeace.org/new-zealand/en/take-action/green-your-life/greenercleaning/

Greenpeace. (2010g). Greenpeace giving: Gifts to save the world. Retrieved October 9,

2010, from http://www.greenpeacegiving.org.nz/index.php

Greenpeace. (2010h). Greenpeace giving: How it works. Retrieved October 9, 2010, from

http://www.greenpeacegiving.org.nz/HowItWorks.php

Greenpeace. (2010i). Help us take action (without getting wet). Retrieved October 9, 2010 , from

http://www.greenpeacegiving.org.nz/Product.php?pid=6\&navcat=3\&navsub=0

Greenpeace. (2010j). In the kitchen. Retrieved October 9, 2010, from

http://www.greenpeace.org/new-zealand/en/take-action/green-your-life/in-thekitchen/

Greenpeace. (2010k). Industrial dairy climate crimes. Retrieved October 9, 2010, from

http://www.greenpeace.org/new-zealand/en/campaigns/climate-change/stopfonterra/

Greenpeace. (20101). Only planet guide. Retrieved October 9, 2010, from 
http://www.greenpeace.org/new-zealand/en/take-action/only-planet/

Greenpeace. (2010m). Seafood markets guide. Retrieved October 9, 2010, from

http://www.greenpeace.org/new-zealand/en/campaigns/oceans/seafood-marketsguide/

Greenpeace. (2010n). Smart farming. Retrieved October 9, 2010, from http://www.greenpeace.org/new-zealand/en/campaigns/climate-change/smartfarming/

Greenpeace. (2010o). Stopping dirty energy. Retrieved October 9, 2010, from http://www.greenpeace.org/new-zealand/en/campaigns/climate-change/dirtyenergy/

Greenpeace. (2010p). Taking action. Retrieved October 9, 2010, from http://www.greenpeace.org/new-zealand/en/about/Our-core-values/taking-action/ Greenpeace. (2010q). Understanding climate change. Retrieved October 9, 2010, from http://www.greenpeace.org/new-zealand/en/campaigns/climate-change/science/

Grey, S. J., \& Nickel, P. M. (2009). Kiwibrand globalisation: Banking on pre-packaged artificial resistance. Reconstruction: Studies in Contemporary Culture, 9(3). Retrieved from http://reconstruction.eserver.org/093/Grey_Nickel.shtml\#1

Gunneng, A. Z. (2006). Discourses and power in sustainable consumption debates: An application of Foucault's methodologies (Unpublished master's thesis). University of Oslo, Blinder, Norway. Retrieved from http://www.duo.uio.no/publ/sum/2006/55349/AndreaxMasterxThesis.pdf

Hardt, M. (1995). The withering of civil society. Social Text, 14(4), 27-44. Retrieved July from http://www.jstor.org/stable/466673 
Hardt, M., \& Negri, A. (2000). Empire. Cambridge, MA: Harvard University Press.

Harvey, D. (2005). A brief history of neoliberalism. Oxford, England: Oxford University Press.

Hawken, P., Lovins, A. \& Lovins, L. H. (1999). Natural capitalism: Creating the next industrial revolution. Boston, MA: Little, Brown and Company.

Hobson, K. (2002). Competing discourses of sustainable consumption: Does the 'rationalisation of lifestyles' make sense? Environmental Politics, 11(2), 95-120. Retrieved from informaworld database (DOI: 10.1080/714000601).

Iedema, R. (2001). Analysing film and television: A social semiotic account of Hospital: an Unhealthy Business. In T. van Leeuwen \& C. Jewitt (Eds.), Handbook of visual analysis (pp. 183-206). London, England: SAGE.

Intergovernmental Panel of Climate Change (2001). Climate Change 2001 - IPCC Third Assessment Report. Retrieved from http://www.ipcc.ch/ipccreports/tar/index.htm Isin, E. F. (2006). Civil society. In A. Harrington, B. Marshall, \& H-P. Muller, Encyclopedia of social theory (pp. 65-66). New York, NY: Routledge.

Jorgensen, M., \& Phillips, L. (2002). Discourse analysis as theory and method. London, England: SAGE.

Kalyvas, A. (2002). The stateless theory: Poulantzas's challenge to postmodernism. In S. Aronowitz, \& P. Bratsis, Paradigm lost: State theory reconsidered (pp. 105-142). Minneapolis, MN: University of Minnesota Press.

Kane, A., \& Neubert, C. (2008). Living Green: The New Zealand hand bookfor an ecofriendly, toxin free, sustainable life. Australia: New Holland. 
Kumar, C. (2005). Foucault and Rorty on truth and ideology: A pragmatist view from the left. Contemporary pragmatism, 2(1), 35-93. Retrieved from http://people.su.se/ guarr/Ideologi/KumaronIdeologyCritiqueJan2005.pdf

Le Heron, R. (2008). Re-conceptualising the landscape of 21 st century investment processes - vital work while engaging with 'sustainable consumption'. Retrieved March 27, 2009, from http://www.landcareresearch.co.nz/news/conferences/ sustainable_consumption/sc_leheronr.pdf

Lemke, T. (2001). 'The birth of bio-politics': Michel Foucault's lecture at the Collège de France on neo-liberal governmentality. Economy and Society, 30(2), 190-207. Retrieved May 21, 2010, from informaworld database (DOI: $10.1080 / 713766674)$.

Lewin, J. A. (2009). Global environmental change and the politics of sustainable consumption in New Zealand (Unpublished master's thesis). University of Waikato, Hamilton, New Zealand. Retrieved from http://hdl.handle.net/10289/2787

Locke, T. (2004). Critical Discourse Analysis. London: Continuum International Publishing Group.

Luke, T. W. (1990). Social theory and modernity: Critique, dissent, and revolution. Newbury Park, California: SAGE Publications.

Luke, T. W. (1996). Generating green governmentality: A cultural critique of environmental studies as a power/knowledge formation. Retrieved from http://www.cddc.vt.edu/tim/tims/tim514a.pdf 
Luke, T. W. (1997a). Ecocritique: Contesting the politics of nature, economy, and culture. Minneapolis, MN: University of Minnesota Press.

Luke, T. (1997b, March). The (un)wise (ab)use of nature: Environmentalism as global consumerism. Paper presented at the annual meeting of the International Studies Association. Retrieved from http://www.cddc.vt.edu/tim/tims/Tim528.PDF

Luke, T. W. (1999a). Capitalism, democracy, and ecology: Departing from Marx. Urbana, IL: University of Illinois Press.

Luke, T. W. (1999b). Environmentality as green governmentality. In E. Darier (Ed.), Discourses of the environment (pp. 121-151). Oxford, England: Blackwell.

Luke, T. W. (2005). Neither sustainable nor development: Reconsidering sustainability in development. Sustainable development, 13, 228-238. Retrieved from Wiley InterScience database (DOI: 10.1002/sd.284).

Luke, T. W. (2006a). On environmentality: Geo-power and eco-knowledge in the discourses of contemporary environmentalism. In N. Haenn, \& R. R. Wilk (Eds.), The environment in anthropology: A reader in ecology, culture, and sustainable living (pp. 257-269). New York, NY: New York University Press. (Reprinted from Cultural critique, 31 (Fall 1995), 57-81)

Luke, T. W. (2006b). The System of Sustainable Degradation. Capitalism, Nature, Socialism, 17(1), 99-112. Retrieved from ProQuest database (DOI: 1011014081).

Luke, T. W. (2009a). An apparatus of answers? Ecologism as ideology in the $21^{\text {st }}$ century. New Political Science, 31(4), 487-498. Retrieved from informaworld database (DOI: 10.1080/07393140903322562). 
Luke, T. W. (2009b, February 15-18). Applied atmospheric aesthetics: Reconsidering the risky art of depicting climate change through PowerPoints, photographs and polemics. Paper presented at the annual meeting of the International Studies Association's 50th Annual Convention, New York, NY.

Luke, T. W. (2009c) Developing planetarian accountancy: Fabrication nature as stock, service, and system for green governmentality. Current Perspectives in Social Theory, 26, 129-159. Retrieved from Emerald Group Publishing Limited (DOI: 10.1108/S0278-1204(2009)0000026008).

Luke, T. W. (2010). Environmentality as empire: The politics and culture of critical climatology. Paper presented at the 2010 TELOS conference, New York University.

Maniates, M. F. (2001). Individualization: Plant a tree, buy a bike, save the world? Global Environmental Politics, 1(3), 31-52. Retrieved from MIT Press Journals database (DOI: 10.1162/152638001316881395).

Marcuse, H. (1991). One dimensional man: Studies in the ideology of advanced industrial society. London: Routledge. (Original work published 1964)

Marcuse, H. (1972). Counterrevolution and revolt. London, England: Allen Lane The Penguin Press.

McLennan, G., Molina, V., \& Peters, R. (1978). Althusser's theory of ideology. In Centre for Contemporary Cultural Studies, University of Birmingham (Eds.), On ideology (pp. 77-105). London, England: Hutchinson.

Milton, K. (1996). Environmentalism and cultural theory: Exploring the role of anthropology in environmental discourse. New York, NY: Routledge. 
Milward, H. B., \& Provan, K. G. (2000). Governing the hollow state. Journal of Public Administration Research and Theory, 10(2), 359-380. Retrieved from http://jpart.oxfordjournals.org

Ministry for the Environment. (1997). State of New Zealand's environment: Production and consumption patterns. Retrieved July 12, 2010, from http://www.mfe.govt.nz/publications/ser/ser1997/index.html

Ministry for the Environment. (2003). Sustainable Development for New Zealand Programme of Action. Retrieved June 11, 2010, from http://www.mfe.govt.nz/publications/sus-dev/sus-dev-programme-of-actionjan03.html

Ministry for the Environment. (2007a). Towards a Sustainable New Zealand: Overview paper. Retrieved June 17, 2010, from http://www.mfe.govt.nz/issues/sustainability/cabinet-papers/pol-07-84.html Ministry for the Environment. (2007b). Towards Zero waste. Retrieved June 10, 2010, from http://www.mfe.govt.nz/issues/sustainability/zero-waste.html

Ministry for the Environment. (2008). About the Environment Act. Retrieved June 10, 2010, from http://www.mfe.govt.nz/laws/environment.html

Ministry for the Environment. (2008a). 25 steps towards sustainability. Retrieved July 8, 2010, from http://www.sustainability.govt.nz/system/files/25-steps-towardssustainability_1.pdf

Ministry for the Environment. (2008b). Towards a sustainable New Zealand: Household sustainability programme. Retrieved July 2, 2010, from http://www.mfe.govt.nz/issues/sustainability/cabinet-papers/pol-07-146.html 
Ministry for the Environment. (2008c). Towards a sustainable New Zealand: Update on the household sustainability programme. Retrieved July 2, 2010, fromhttp://www.mfe.govt.nz/issues/sustainability/cabinet-papers/pol-07-457.html Ministry for the Environment. (2009a). About us. Retrieved July 2, 2010, from http://www.sustainability.govt.nz/content/about-us

Ministry for the Environment. (2009b). Createledit my 'next step' plan. Retrieved July 2, 2010, from http://www.sustainability.govt.nz/pledge/edit

Ministry for the Environment. (2009c). Ecolabels. Retrieved July 12, 2010, from http://www.sustainability.govt.nz/shopping/ecolabels

Ministry for the Environment. (2009d). I want to chose products and services that reduce my environmental impact. Retrieved July 12, 2010, from http://www.sustainability.govt.nz/goal/i-want-chose-products-and-servicesreduce-my-environmental-impact

Ministry for the Environment. (2009e). Resources. Retrieved July 2, 2010, from http://www.sustainability.govt.nz/content/resources-0

Ministry for the environment. (2009f). Rubbish. Retrieved July 5, 2010, from http://www.sustainability.govt.nz/rubbish

Ministry for the Environment. (2009g). Shopping. Retrieved July 12, 2010, from http://www.sustainability.govt.nz/shopping

Ministry for the Environment. (2009h). Smart shopping. Retrieved July 12, 2010, from http://www.sustainability.govt.nz/shopping/smart-shopping

Ministry for the Environment. (2009i). Sustainability. Retrieved June 10, 2010, from http://www.mfe.govt.nz/issues/sustainability/index.html 
Ministry for the Environment. (2009j). The carbon neutral public service programme.

Retrieved June 10, 2010, from

http://www.mfe.govt.nz/issues/sustainability/public-service-carbonneutrality.html

Ministry for the Environment. (2009k). What happens to household recycling? Retrieved July 12, 2010, from http://www.sustainability.govt.nz/rubbish/what-happenshousehold-recycling

Ministry for the Environment. (2010a). Capital. Retrieved July 8, 2010, from http://www.mfe.govt.nz/issues/sustainable-industry/toolsservices/concepts.php?id=6

Ministry for the Environment. (2010b). Emerging market. Retrieved July 2, 2010, from http://www.mfe.govt.nz/issues/sustainable-industry/toolsservices/subjects.php?id=33

Ministry for the Environment. (2010c). Five easy steps towards sustainability. Retrieved July 8, 2010, from http://www.mfe.govt.nz/issues/sustainable-industry/toolsservices/five-steps.php

Ministry for the Environment. (2010d). Household sustainability programme. Retrieved June 17, 2010, from http://www.mfe.govt.nz/publications/sus-dev/householdsustainability-programme-oct07/household-sustainability-programme-oct07.html Ministry for the Environment. (2010e). People. Retrieved July 8, 2010, from http://www.mfe.govt.nz/issues/sustainable-industry/toolsservices/concepts.php?id=7 
Ministry for the Environment. (2010f). Processes. Retrieved July 8, 2010, from http://www.mfe.govt.nz/issues/sustainable-industry/toolsservices/concepts.php?id=8

Ministry for the Environment. (2010g). Simply sustainable business model. Retrieved June 17, 2010, from http://www.mfe.govt.nz/issues/sustainable-industry/toolsservices/model.php

Ministry for the Environment. (2010h). Strategy. Retrieved July 8, 2010, from http://www.mfe.govt.nz/issues/sustainable-industry/toolsservices/concepts.php?id=5

Ministry for the Environment. (2010i). Sustainable industry. Retrieved July 2, 2010, from http://www.mfe.govt.nz/issues/sustainable-industry/

Ministry for the Environment. (2010k). Sustainability: A definition. Retrieved July 12, 2010, from http://www.mfe.govt.nz/issues/sustainable-industry/toolsservices/definition.php

Ministry of Education. (n.d.). Education for sustainability. Retrieved June 11, 2010, from http://efs.tki.org.nz/

Mitchell, T. (1991). The Limits of the State: Beyond Statist Approaches and Their Critics. The American Political Science Review, 85(1), 77. Retrieved ABI/INFORM Global. (Document ID: 1515088).

Munshi, D., \& Kurian, P. (2005). Imperializing spin cycles: A postcolonial look at public relations, greenwashing, and the separation of publics. Public Relations Review, 31, 513-520. Retrieved from Sciencedirect database (doi:10.1016/j.pubrev.2005.08.010). 
Naess, A. (2005). The shallow and the deep, long-range ecology movement. A summary. In A. Naess \& A. Drengson (Eds.), The selected works of Arne Naess (Vol. 10) (pp. 7-12). Dordrecht, The Netherlands: Springer. Retrieved from Springerlink database (DOI: 10.1007/978-1-4020-4519-6_85).

National Institute of Water \& Atmospheric Research. (2008). The greenhouse effect. Retrieved September 21, 2010, from http://www.niwa.co.nz/ourscience/climate/information-and-resources/clivar/greenhouse

New Zealand Government. (2010). Emissions trading scheme basics. Retrieved October 10, 2010, from http://www.climatechange.govt.nz/emissions-tradingscheme/about/basics.html

Paterson, M. (2008). Sustainable consumption? legitimation, regulation, and environmental governance. In J. Park, K. Conca, \& M. Finger (Eds.), The crisis of global environmental governance: Towards a new political economy of sustainability (pp. 110-131). London, England: Routledge.

Princen, T., Maniates, M., \& Conca, K. (2002). Confronting consumption. Cambridge, MA: MIT Press.

Ransom, J. S. (1997). Foucault's discipline: The politics of subjectivity. Durham, NC: Duke University Press.

Ritzer, G., Goodman, D., \& Wiedenhoft, W. (2003). Theories of consumption. In G. Rtizer \& B. Smart (Eds.), Handbook of social theory (pp. 410-427). London, England: SAGE.

Rose, N. S. (1999). Powers of freedom: Reframing political thought. Cambridge, England: Cambridge University Press. 
Sargisson, L. \& Lyman Tower, S. (2004). Living in Utopia: New Zealand's intentional communities. Aldershot, England: Ashgate.

Simon, R. (1982). Gramsci's political thought: An introduction. London, England: Lawrence And Wishart.

Skocpol, T. (1985). Bringing the state back in: Strategies of analysis in current research. In P. B. Evans, D. Rueschemeyer, \& T. Skocpol (Eds.), Bringing the state back in (pp. 3- 37). Cambridge, England: Cambridge University Press.

Smart, B. (1983). Foucault, Marxism, and critique. London, England: Routledge \& Kegan Paul.

Smart, B. (2010). Consumer society: Critical issues and environmental consequences. London, England: SAGE.

Sorensen, E., \& Torfing, J. (2005). Network governance and post-liberal democracy. Administrative Theory \& Praxis, 27(2), 197-237. Retrieved from ProQuest database (ProQuest document ID: 867287631).

Thompson, J. B. (1990). Ideology and modern culture. Cambridge, England: Polity Press. Veblen, T. (2008). The theory of the leisure class. Champaign, Illionois: Project Gutenberg. (Original work published 1899). Retrieved from http://www.netlibrary.com.helicon.vuw.ac.nz/Reader/

Vighi \& Feldner. (2007). Ideology critique or discourse analysis? Zizek against Foucault. European Journal of Political Theory, 6(2), 141-159. Retrieved from Sage Journals Online (doi: 10.1177/1474885107074347).

Weber, M. (2002). The protestant ethic and the spirit of capitalism (T. Parsons, Trans.). London, England: Routledge. (Original work published 1930) 
Wood, L. A., \& Kroger, R. O. (2000). Doing discourse analysis: Methods for studying action in talk and text. Thousand Oaks, California: Sage Publications.

World Commission on Environment and Development. (1987). Our common future: The World Commission on Environment and Development. Oxford, England: Oxford University Press.

Zizek, S. (1994). The spectre of ideology. In S. Zizek (Ed.), Mapping ideology (pp. 1-33). London, England: Verso.

Zizek, S. (1997). The plague of fantasies. London, England: Verso.

Zizek, S. (1998). Risk society and its discontents. Historical Materialism, 2(1), 143-154. Retrieved from Swetswise database (ISSN: 1465-4466)

Zizek, S. (2004). From politics to biopolitics . . . and back. The South Atlantic Quarterly, 2(3), 501-521. Retrieved from Academic Search Premier database (Accession Number: 13296907).

Zizek, S. (2006). Passion in the era of decaffeinated belief. In M. Hoelzl \& G. Ward (Eds.), Religion and political thought (pp. 237-242). London, England: Continuum.

Zizek, S. (2008a). The sublime object of ideology (New ed.). London, England: Verso. Zizek, S. (2008b). The ticklish subject (New ed.). London, England: Verso. 


\section{Appendix A}

Generation Diversity Advertisement: Scenes, Shots, Dialogue, and Lyrics (Genesis Energy, 2010g)

Scene one: Pukeko on beach front.

Shot 1:

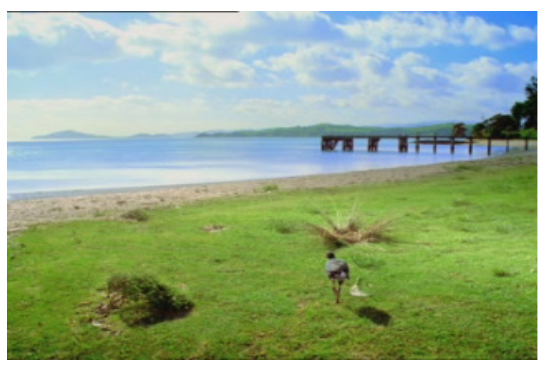

Images: A Pukeko walks towards a Cortaderia selloana (Toi toi or Pampas Grass) flower and stem, and picks it up.

Lyrics: "You know that there is nothing that I wouldn't . .

Shot 2:

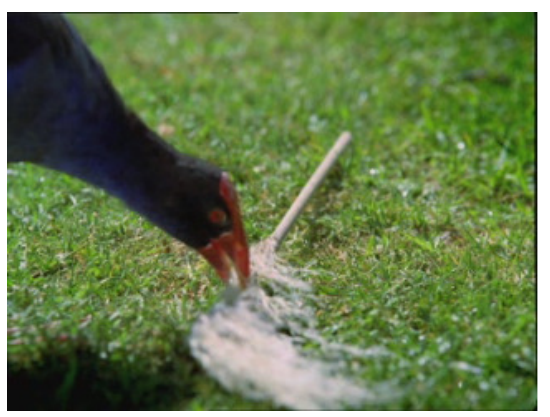

Images: A close-up shot of the Pukeko picking up the flower and stem . . .

Lyrics: . . do do: . .

Shot 3:

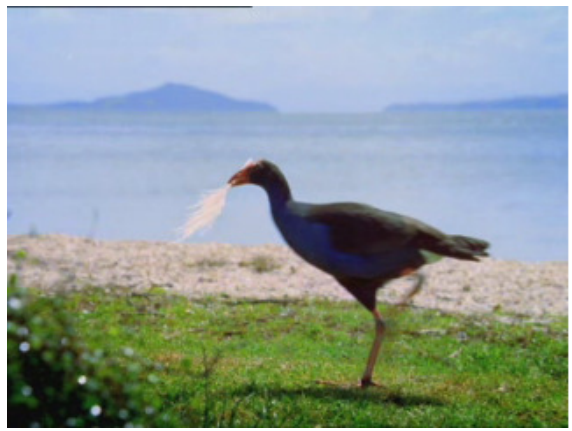

Images: . . . and taking it over to . . .

Lyrics: ... when it comes to doing ... 
Shot 4:

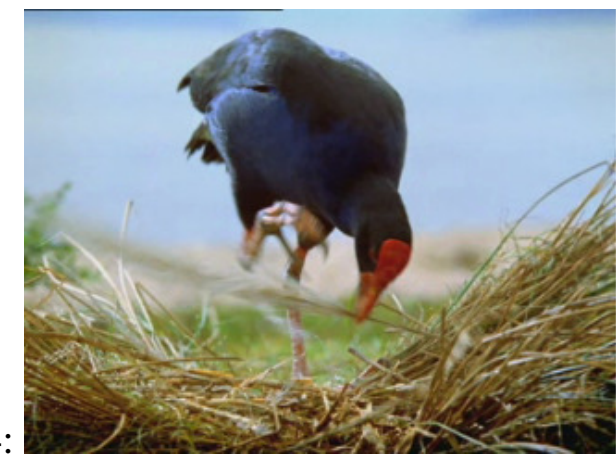

Images: . . . its nest.

Lyrics: . . stuff for you:”.

Scene two: The Pukeko on a hillside.

Shot 5:

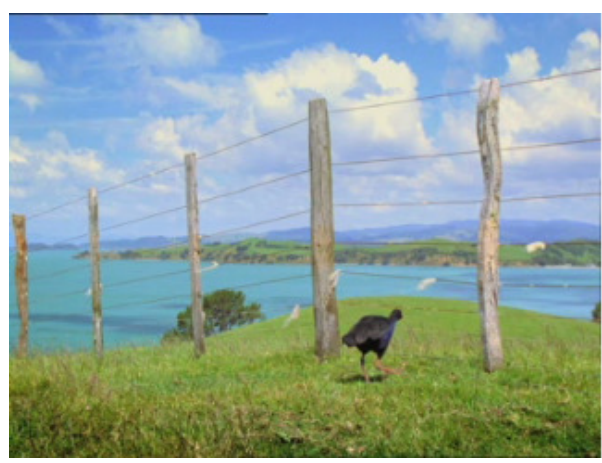

Images: The Pukeko is walking towards a fence . . .

Shot 6:

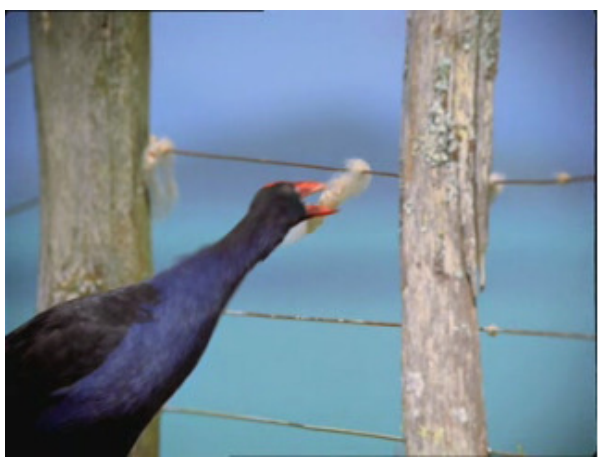

Images: . . and picks, what appears to be, a piece of lambs wool from it. Lyrics: “Ain't no mountain high enough it's . . . 
Shot 7:

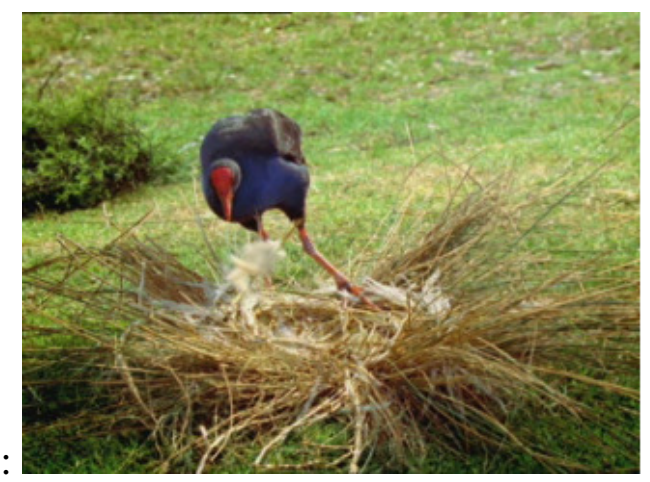

Images: The Pukeko then adds the wool to its partially constructed nest. Lyrics: . . true:".

Scene three: Front doorstep of a house

Shot 8:

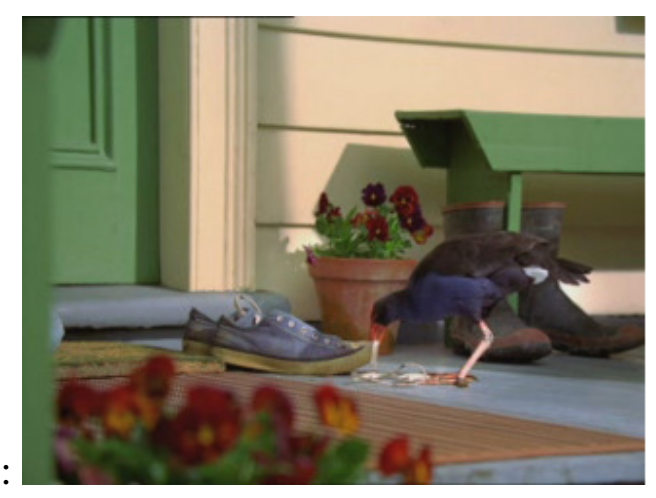

Images: The Pukeko is removing shoelaces from a shoe . .

Lyrics: True, true, ...

Shot 9:

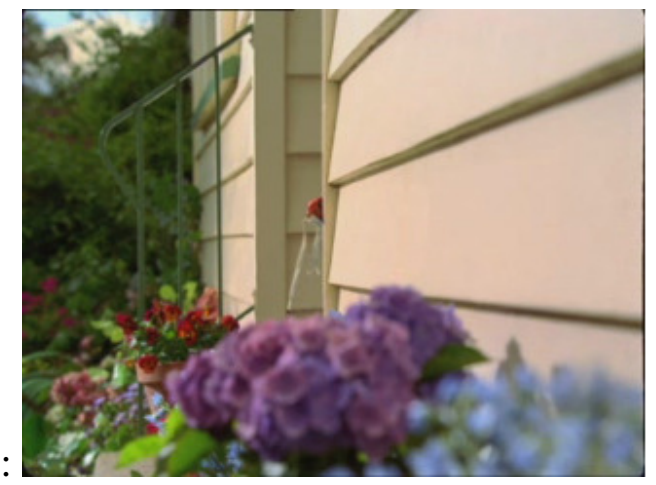

Images: . . . and then appears to leave the property (to presumably take the laces back to its nest).

Lyrics: ... true, true, true ah (ooo)". 
Scene four: Office.

Shot 10:

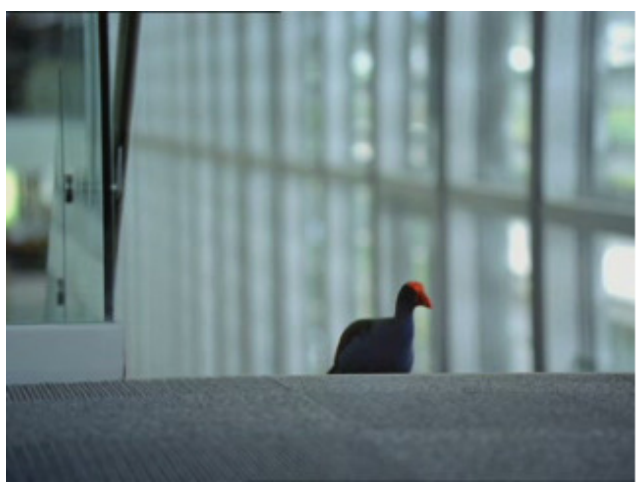

Images: The Pukeko is walking up a flight of stairs . .

Lyrics: “(Doop doop do de doop doop ...

Shot 11:

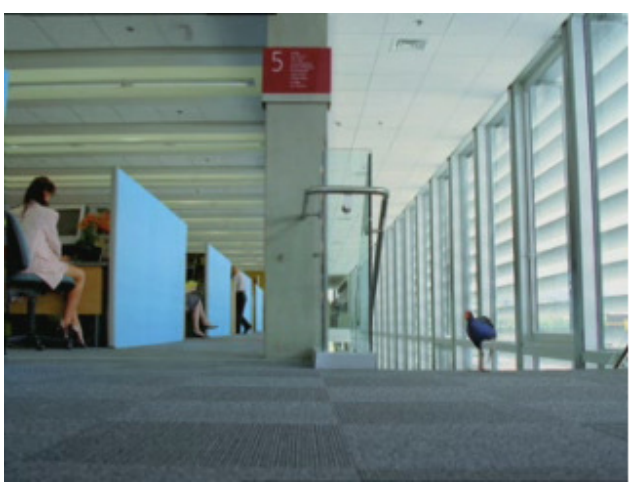

Images: . . . and enters an office.

Lyrics: ... de do do) ...

Shot 12:

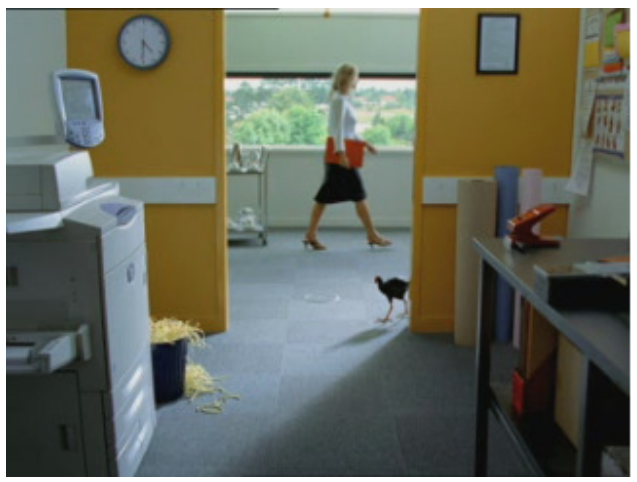

Images: The Pukeko then enters into a room with office supplies . . . Lyrics: . . (doop doop do ... 
Shot 13:

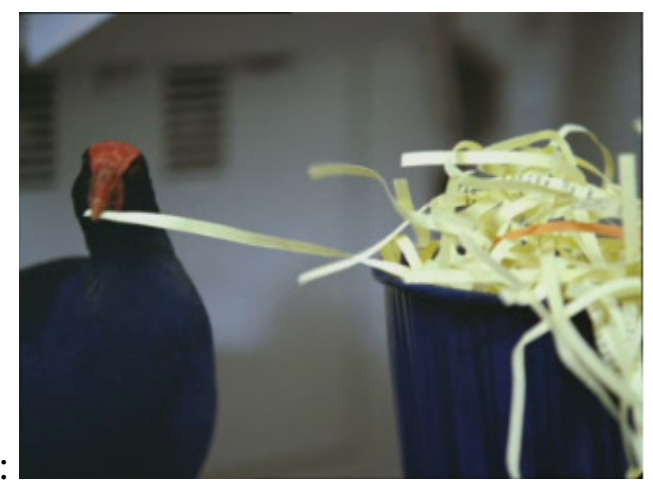

Images: . . . and removes a strand of waste paper from a bin.

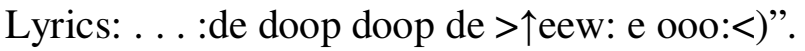

Dialogue: "If you're able to pick and choose ...

Scene five: Beach front.

Shot 14:

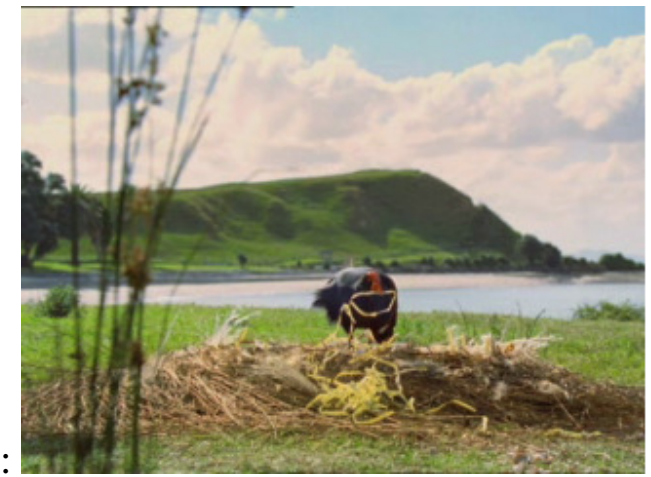

Images: The Pukeko appears to be constructing its nest using the paper it took from the office.

Lyrics: "(Doop doop do de doop doop de . .

Dialogue: ... from many sources ...

Shot 15:

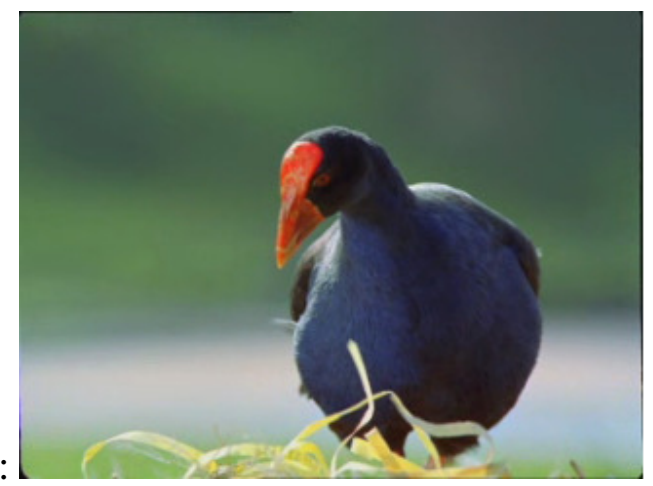

Images: The Pukeko appears to be inspecting its nest. 
Lyrics: . . . do do, ${ }^{\circ}$ doop doop do de doop ...

Dialogue: ... you're less likely to run out ...

\section{Shot 16:}

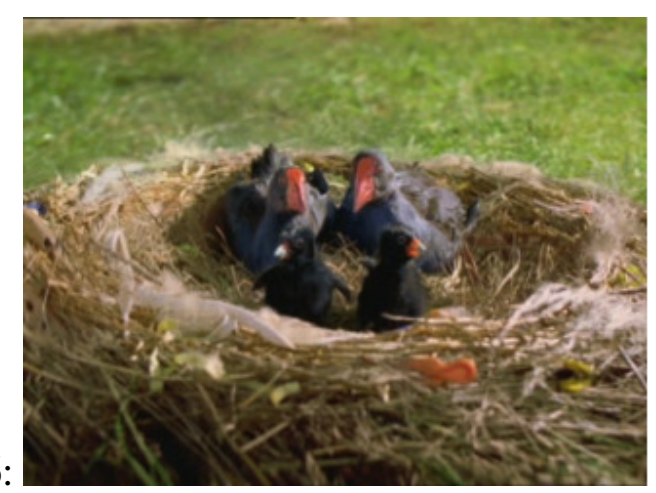

Images: It appears as though the Pukeko has finished constructing its nest and is now sitting in its nest with three other Pukekos.

Lyrics: . . doop de >eew: e ooo: $\left.<^{\circ}\right) \ldots$

Dialogue: . . . so your $\uparrow$ future is more secure".

Shot 17:
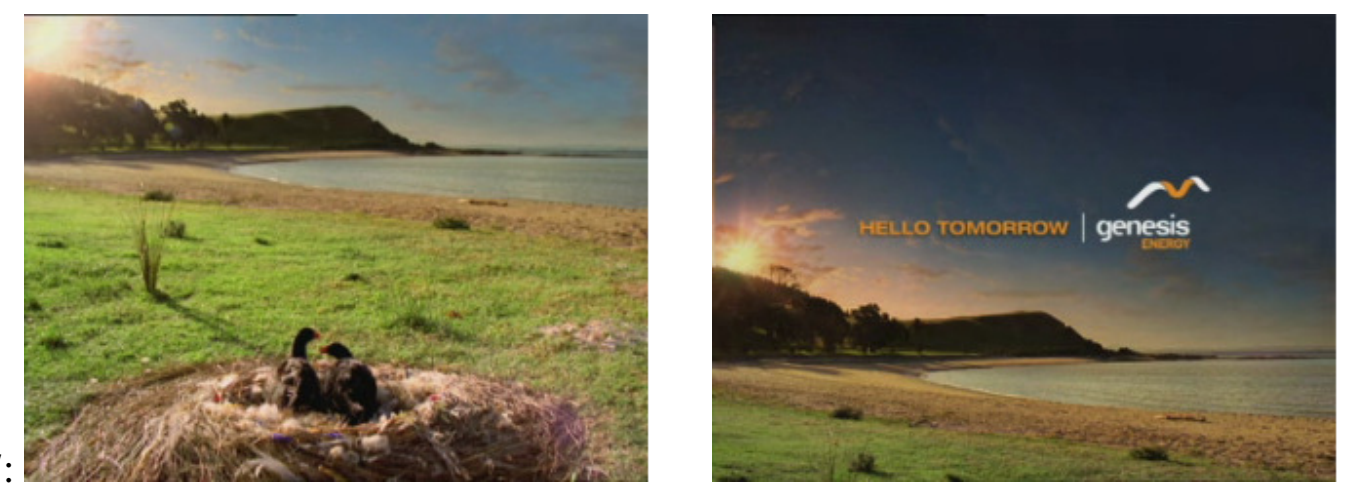

Images: The Pukekos are sitting in there nest while the camera tilts upwards and focuses on the beach front and Genesis Energy's logo appears on the screen.

Lyrics: “ooh: yeah:”.

Dialogue: “That's why at Genesis Energy, we generate power from more sources than anyone else". 


\section{Appendix B}

\section{Climate Change Advertisement: Scenes, Shots, Dialogue, and Lyrics}

(GenesisEnergy, 2010f)

Scene one: Pukekos on beach front.

Shot 1:

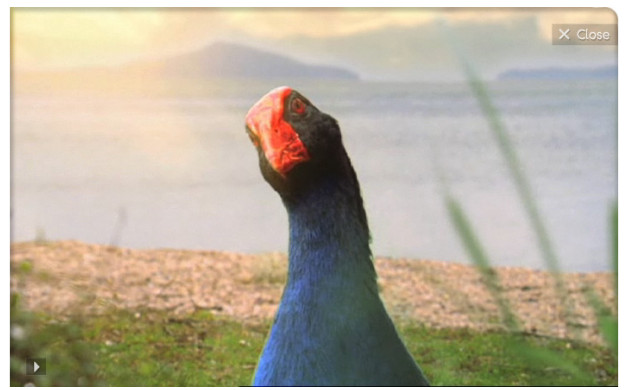

Images: A Pukeko is looking towards someone or something with its head skewed on an angle. The Pukeko then looks down ...

Lyrics: "You know that there is ...

Shot 2:

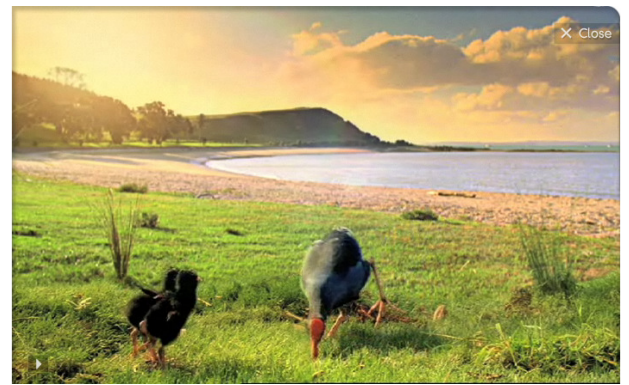

Images: . . . and resumes picking up something in front of the baby Pukekos.

Lyrics: . . nothing that I wouldn't do: . .

Scene two: Pukekos on front lawn.

Shot 3:

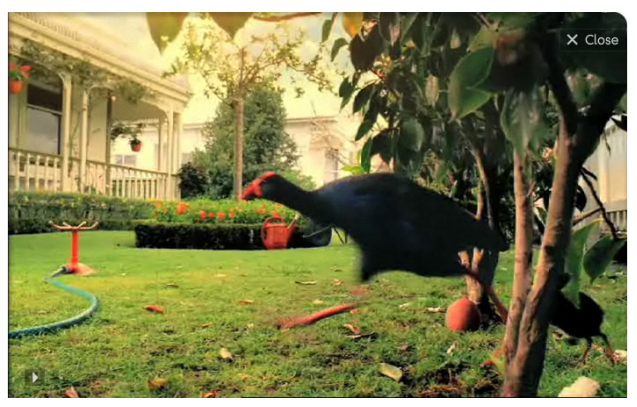


Images: The Pukekos then walk onto a house's front lawn by walking through a row of trees that separate the front lawn from the beach.

Lyrics: . . when it comes to doing stuff for you:".

Shot 4:
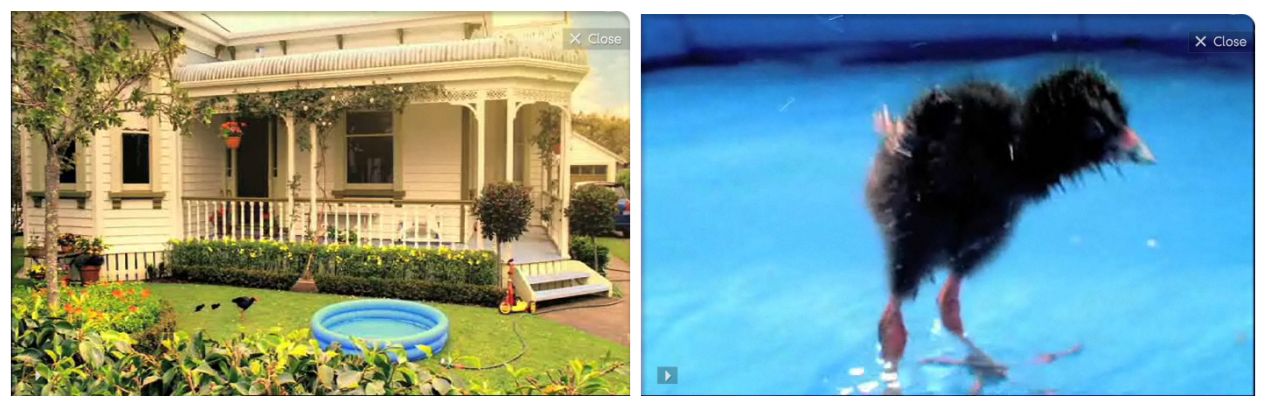

Images: The Pukekos then walk across the front lawn, which contains a child's

paddling pool partially filled with water. Rather than walking around the paddling pool the baby Pukekos climb over it while the adult Pukeko looks in at them.

Lyrics: “Ain't no mountain high enough it's true:. True, true, true . . .

Shot 5:

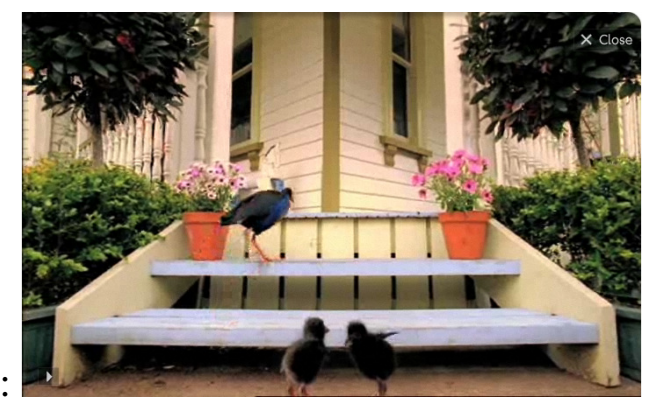

Images: The Pukekos arrive at the front of the house and walk up the steps.

Lyrics: . . true, true ah (ooo)."

Scene three: Pukekos entering house.

Shot 6:
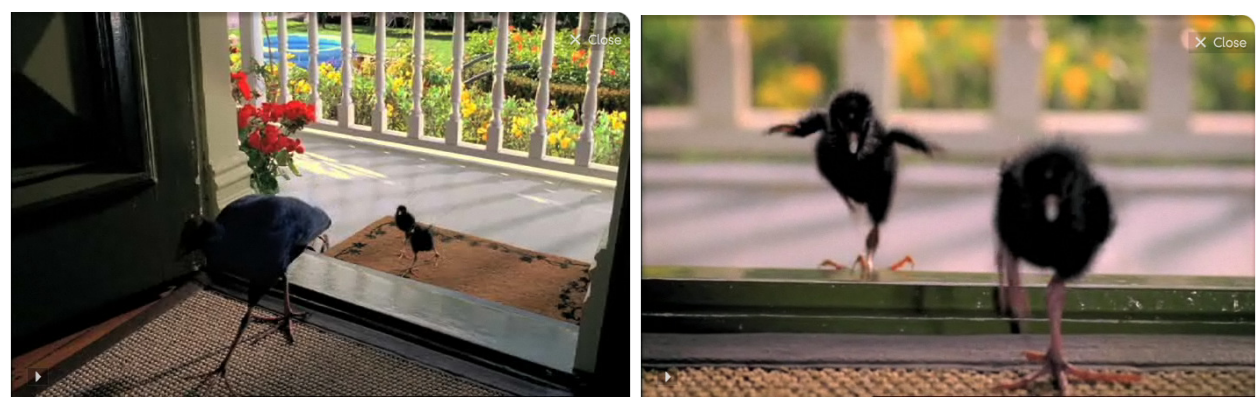

Images: The Pukekos then enter through the front door of the house, which is open. The adult Pukeko enters and the baby Pukekos follow behind the adult Pukeko.

Lyrics: “(Doop doop do de doop doop de do do) . . . 
Shot 7:

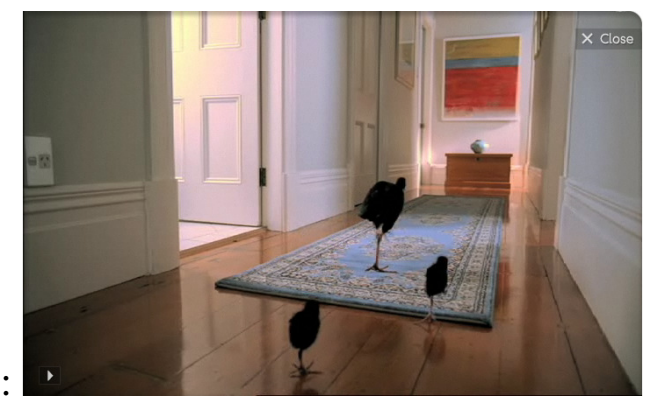

Images: The Pukekos then walk down a hallway . . .

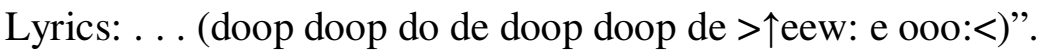

Scene four: Pukekos entering a room in the house.

Shot 8:

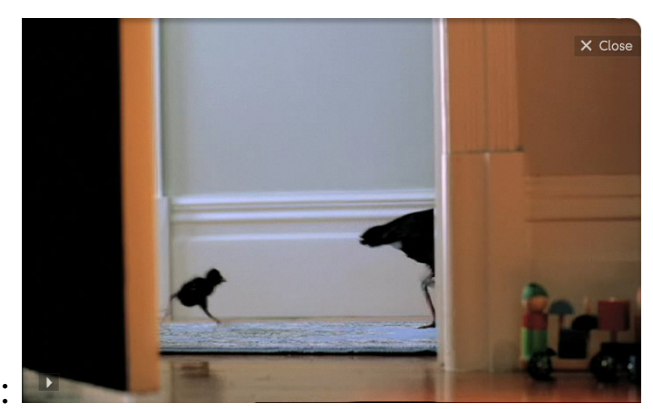

Images: . . . and pass a room that has its door open.

Lyrics: "(Doop doop do de doop doop de do do) ...

Shot 9:

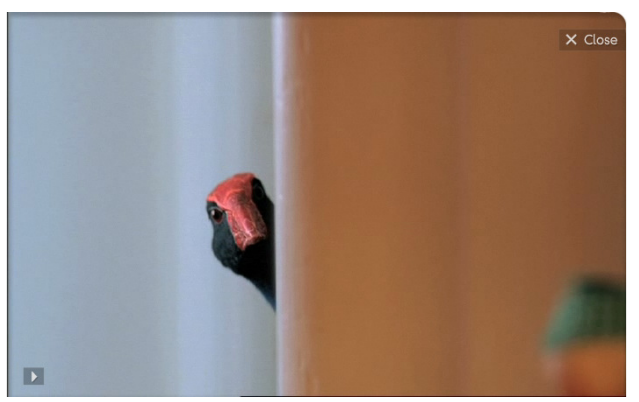

Images: The adult Pukeko looks into the room it just walked past . .

Dialogue: "We can all do our bit ...

Lyrics: $\left({ }^{\circ}\right.$ doop doop do de doop doop de >eew: e ooo: $\left.<^{\circ}\right) \ldots$ 
Shot 10:

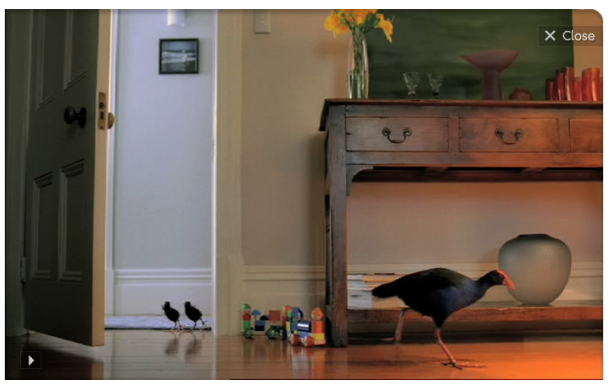

Images: . . and enters the room.

Dialogue: . . for climate change ...

Lyrics: ( ${ }^{\circ}$ doop doop do de doop doop de $>\uparrow$ eew: e ooo: $\left.<^{\circ}\right)$ ".

Shot 11:

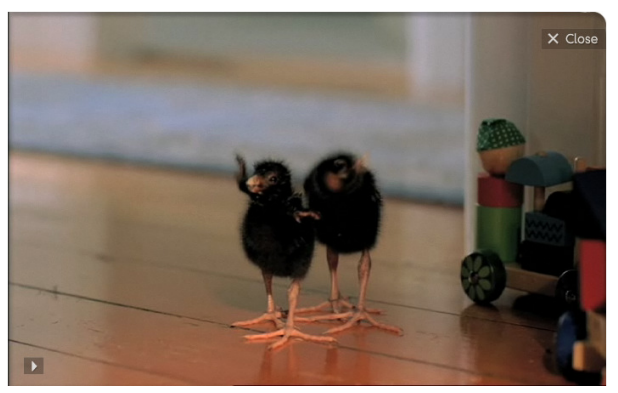

Images: The baby Pukekos then enter the room as well.

Dialogue: . . . if we make it part of our everyday lives".

Lyrics: “ooh: ...

Shot 12:
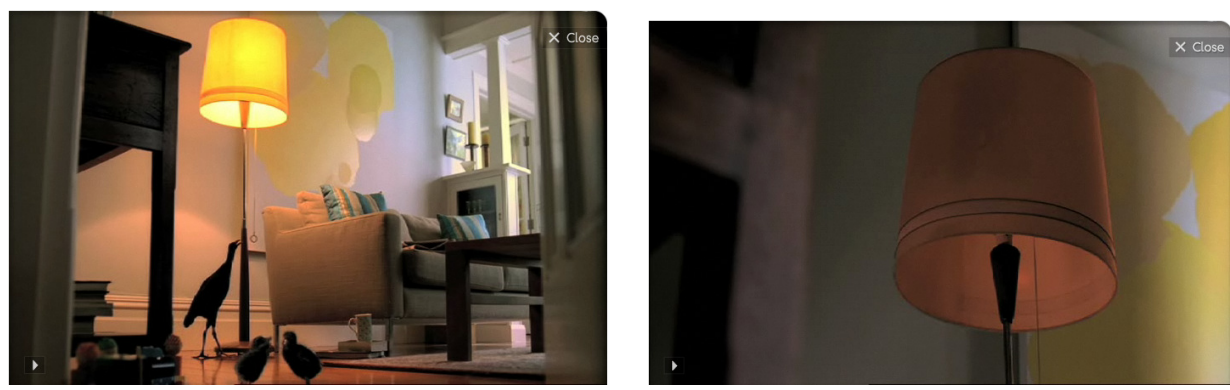

Images: The adult Pukeko walks towards a lamp and turns it off by pulling on its cord.

Dialogue: "Together we can make a big difference to tomorrow".

Lyrics: . . yeah:" 
Shot 13:

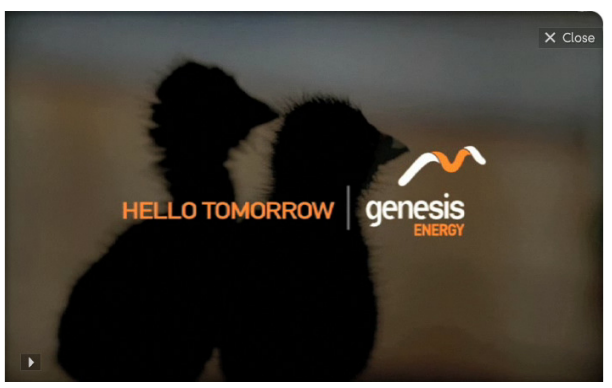

Images: There is a close up of the baby Pukekos and the shot begins to fade. The words "hello tomorrow" and Genesis Energy's logo appears on the screen. 


\section{Appendix C}

\section{Transcript Notational Conventions}

Notational conventions taken from Wood \& Kroger (2000, pp. 193-194).

under; pie Underlining indicates emphasis.

${ }^{\circ}$ soft $^{\circ} \quad$ Degree signs indicate talk that is noticeably more quiet than surrounding talk.

$>$ fast $<\quad$ "Less than" signs indicate talk that is noticeably faster or slower than the surrounding talk.

$\uparrow$ Word $\quad$ Upward pointing arrows indicate marked rising shifts in intonation in the talk immediately following.

(word) Unclear speech or noise.

ho:me A colon indicates an extension of the sound or syllable that it follows. 
